\title{
In Situ Redox Manipulation of Subsurface Sediments from Fort Lewis, Washington: Iron Reduction and TCE Dechlorination Mechanisms
}

\author{
J. E. Szecsody \\ J. S. Fruchter \\ D. S. Sklarew \\ J. C. Evans
}

March 2000

Pacific Northwest National Laboratory

Richland, Washington 99352 



\section{DISCLAIMER}

This report was prepared as an account of work sponsored by an agency of the United States Government. Neither. the United States Government nor any agency thereof, nor any of their employees, make any warranty, express or implied, or assumes any legal liability or responsibility for the accuracy, completeness, or usefulness of any information, apparatus, product, or process disclosed, or represents that its use would not infringe privately owned rights. Reference herein to any specific commercial product, process, or service by trade name, trademark, manufacturer, or otherwise does not necessarily constitute or imply its endorsement, recommendation, or favoring by the United States Government or any agency thereof. The views and opinions of authors expressed herein do not necessarily state or reflect those of the United States Government or any agency thereof. 


\section{DISCLAIMER}

Portions of this document may be illegible in electronic image products. Images are produced from the best available original document. 


\section{Summary}

The feasibility of chemically treating sediments from the Ft. Lewis, Washington, Logistics Center to develop a permeable barrier for dechlorination of trichloroethylene (TCE) was investigated in a series of laboratory experiments. The proposed remediation technology uses a chemical treatment to reduce existing iron in sediments, then relies on the ability of the ferrous iron to act as an electron donor to dechlorinate organic contaminants. The effects of temperature, partial iron reduction, and flow on these redox reactions were also studied to ascertain how to achieve viable TCE dechlorination rates at the field scale. The fraction of reducible iron in Ft. Lewis sediments would create a reduced zone that would remain anoxic for $\sim 300$ pore volumes. Because the kinetics of the reduction reaction are third-order, significant amounts of iron are reduced early in the reduction period. The reduction is slower at later times. Because the slower disproportionation reaction destroys the remaining dithionite, specific sediment/solution contact times $\left(32 \mathrm{~h}\right.$ at $25^{\circ} \mathrm{C}, 100 \mathrm{~h}$ at $\left.12^{\circ} \mathrm{C}\right)$ are needed to efficiently reduce $80 \%$ of the iron in the sediment.

When the $\mathrm{pH}$ buffer concentration was less than four times the dithionite concentration, there was a significant loss in reduction efficiency along with a significant $\mathrm{pH}$ decrease and increased iron mobility. The long contact times needed for reduction at ambient aquifer temperature coupled with density effects of the solution at the field scale indicate that heated injections (with high concentration of $\mathrm{pH}$ buffer) can efficiently reduce the sediment zones of interest.

Dithionite-reduced Ft. Lewis sediments were shown to degrade TCE in Ft. Lewis groundwater at sufficiently fast rates $(1.2 \mathrm{~h}$ to $19 \mathrm{~h}$ ) during static and transport experiments to create a permeable barrier at the field scale. The TCE degradation rate can be calculated for all sediments from the product of the intrinsic degradation rate $(0.0034 / \mathrm{h} \mu \mathrm{mol})$ and the mass of reduced iron (range of $12 \mu \mathrm{mol} / \mathrm{g}$ to $126 \mu \mathrm{mol} / \mathrm{g}$; averaged $=63 \mu \mathrm{mol} / \mathrm{g}$ ). Products of TCE dechlorination clearly show that $99.5 \%$ to $100 \%$ is occurring via reductive elimination, producing acetylene, ethylene, and chloroacetylene. The TCE degradation rate decreased up to 3 orders of magnitude in partially reduced sediment. This departure on fraction of reduced iron has significant implications, because uniform full sediment reduction is not possible at the field scale. Although minimally reduced sediment had nearly no TCE reactivity, $>40 \%$ reduced sediment resulted in TCE reduction rates that were viable at the field scale $(<65 \mathrm{~h})$. The second-order dependence of the TCE dechlorination rate on the fraction of reduced iron demonstrates the significant role of the iron oxide surface (as a catalyst or for surface coordination) in addition to $\mathrm{Fe}^{\mathrm{II}}$ as the electron donor for TCE dechlorination to proceed. Reduced sediment barrier longevity was demonstrated in a column in which TCE was degraded for over 230 pore volumes. The design of a field-scale reduced iron barrier should to be wide enough to allow the TCE to be degraded to below the maximum concentration level (MCL) during the groundwater transport time through the barrier ( 10 half-lives). Because few sites are homogeneous, barriers are typically designed wider than needed to account for the spatial variability in the iron content and the velocity variability resulting from hydraulic conductivity variability and temporal changes. 



\section{Contents}

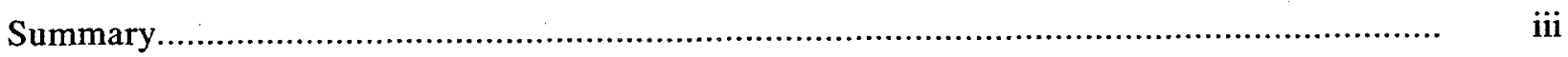

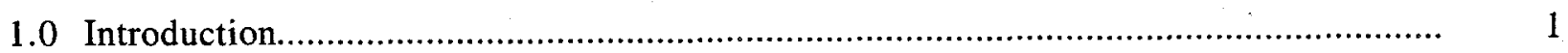

2.0 Geochemical Reactions for Remediation of TCE ..............................................

2.1 Iron Reduction Mechanism........................................................................ 3

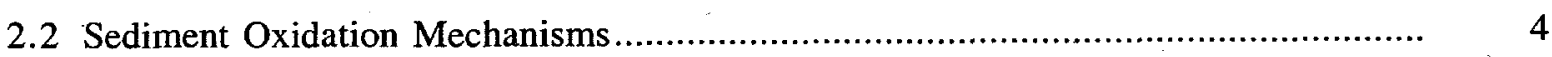

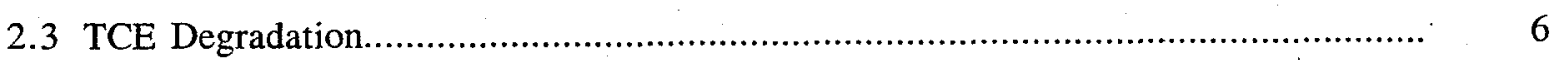

2.4 Partial Iron Reduction and Temperature Effects on TCE Degradation..................... 8

3.0 Experimental and Modeling Methods .............................................................. 11

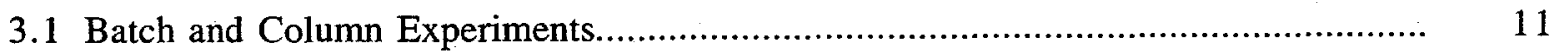

3.2 Experimental Data Quality Control ............................................................ 16

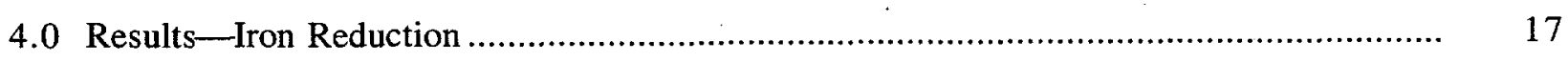

4.1 Sediment Reduction in Batch Systems..................................................... 17

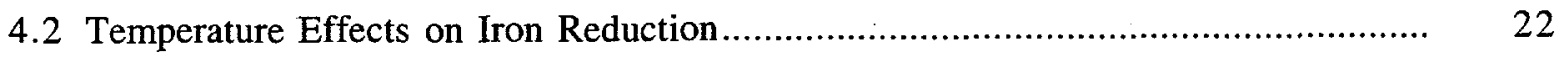

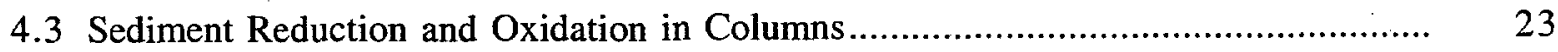

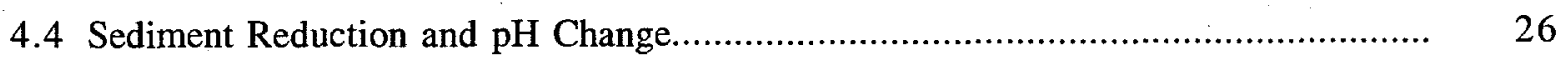

4.5 Geochemical Changes During Redox....................................................... 28

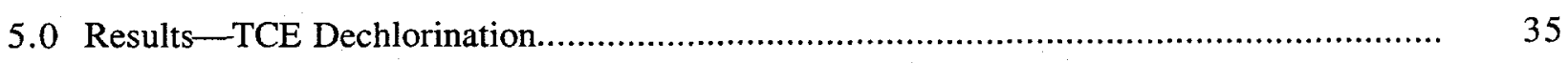

5.1 TCE Dechlorination Pathway and Rate....................................................... 35

5.2 Influence of Partial Iron Reduction on the TCE Degradation Rate ........................ 37

5.3 Temperature Effects on the TCE Dechlorination Rate .................................... 39

5.4 TCE Dechlorination During Reactive Transport............................................ 39

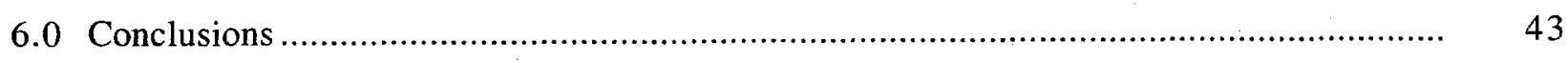

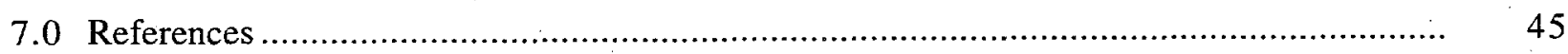


Appendix A - Batch Reduction Experiments......................................................... A.1

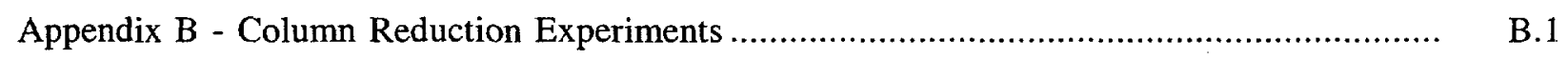

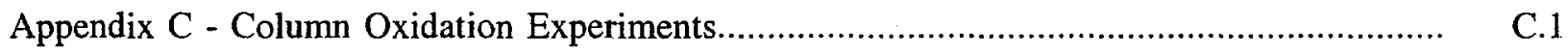

Appendix D - Batch TCE Experiments ................................................................. D.

Appendix E - Column TCE Experiments ................................................................... E. 1 


\section{Figures}

1 Conceptual diagram showing the influence of the redox barrier as a function of time on: a) dissolved oxygen in water which is the main barrier oxidant, b) the redox conditions of groundwater, and c) TCE and degradation products resulting from dechlorination by the reduced iron in the redox barrier

2 Batch experiment of Ft. Lewis sediment reduction by dithionite at different concentrations. Dithionite use at short time $(<100 \mathrm{~h})$ is mainly due to iron reduction and at $>100 \mathrm{~h}$ is mainly due to disproportionation. Experiments conducted starting with $0.11 \mathrm{~mol} / \mathrm{L}$ sodium dithionite (a) and $0.008 \mathrm{~mol} / \mathrm{L}$ sodium dithionite (b)

3 Simulation of iron reduction with: a) third-versus first-order iron reduction fit to data, b) simulated iron reduction at different temperature with linear time, and c) log time.......

4 Change in a) iron reduction and b) disproportionation rate from $2^{\circ} \mathrm{C}$ to $42^{\circ} \mathrm{C}$

5 Dithionite influent and effluent in a reactive sediment column with a sediment-dithionite contact time of: a) 4.0 hours, and b) 12.8 hours

6 Oxidation of a reduced sediment column with dissolved oxygen in water with:

a) residence time of $0.72 \mathrm{~h}$ in a highly reduced sediment column, and b) residence time of $0.58 \mathrm{~h}$ in a partially reduced sediment column.

7. Sediment reduction column experiments at different potassium carbonate concentration relative to sodium dithionite concentration with the resulting $\mathrm{pH}$ and the total aqueous iron concentration b) measured both measured in effluent samples.

8 Changes in $\mathrm{Fe}^{\mathrm{Il}}$ and $\mathrm{Fe}^{\mathrm{II}}$ phases in partially reduced sediment, as characterized by: a) $5 \mathrm{M} \mathrm{HCl}$ extractions for total $\mathrm{Fe}^{\mathrm{II}}$ and $\mathrm{Fe}^{\mathrm{II}}$ phases, and b) $1 \mathrm{M} \mathrm{CaCl}_{2}$ for extracting adsorbed $\mathrm{Fe}^{\mathrm{II}}$ and the difference of a $0.5 \mathrm{M} \mathrm{HCl}$ and $1 \mathrm{M} \mathrm{CaCl}_{2}$ for $\mathrm{FeCO}_{3}$ and $\mathrm{FeS}$.....

9 Degradation of $2.7 \mathrm{ppm}$ TCE by reduced sediment to chloroacetylene and acetylene showing that reductive elimination is the major reaction pathway....

10 TCE dechlorination rate in partially reduced sediment, as shown by: a) acetylene production rate with differing fraction reduced iron, b) intrinsic TCE dechlorination rate dependence on the fraction of reduced iron, and c) theoretical dependence of adsorbed $\mathrm{Fe}^{\mathrm{II}}$ that are adjacent on a goethite surface as a function of the fraction surface coverage.

11 Dechlorination of TCE at different temperature as shown by: a) acetylene production rate over time in experiments at different temperature, and b) regular dependence of the intrinsic TCE dechlorination rate coefficient with temperature.

12 TCE dechlorination in a long-term column experiment as sediment is slowly oxidized, as shown by: a) TCE influent and effluent, and b) acetylene and ethylene. 


\section{Tables}

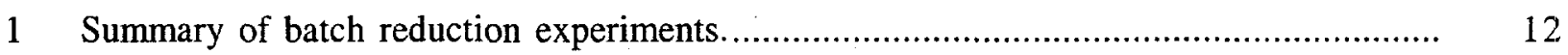

2 Summary of reduction and oxidation column experiments.................................. 13

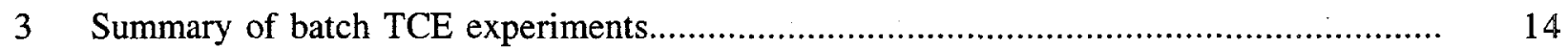

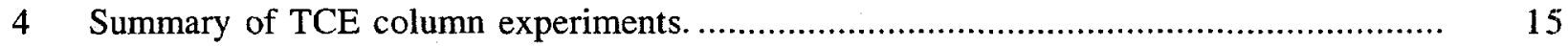

5 Fraction of dithionite use for iron reduction and disproportionation at $10^{\circ} \mathrm{C}$ and $25^{\circ} \mathrm{C} \ldots . . \quad 23$

6 Summary of reduction experiments with different $\mathrm{pH}$ buffer concentration ................... 28

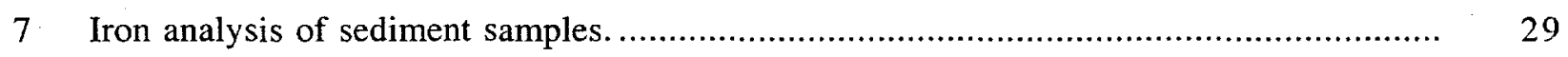

8 Summary of iron oxide phases changes during reduction and oxidation....................... 30

9 Metal mobility during sediment reduction in columns.......................................... 32

10 Metal mobility during sediment oxidation in columns....................................... 32

11 Dependence of the TCE degradation rate on reduced iron mass............................... 36

12 Dependence of the TCE degradation rate on the fraction of reduced iron..................... 37 


\subsection{Introduction}

Pacific Northwest National Laboratory (PNNL) conducted a bench-scale study to determine how effective chemically treated Ft. Lewis sediments can degrade trichloroethylene (TCE). The objectives of this experimental study were to quantify: 1) sediment reduction and oxidation reactions, 2) TCE degradation reactions, and 3) other significant geochemical changes that occurred. Sediment reduction and oxidation were investigated to determine the mass of reducible iron in the Ft. Lewis sediments and the rate of this reduction and subsequent oxidation at different temperatures. The temperature dependence was needed to be able to predict field-scale reduction in the relatively cold $\left(\sim 11^{\circ} \mathrm{C}\right) \mathrm{Ft}$. Lewis aquifer. Results of these experiments were used in conjunction with other geochemical and hydraulic characterization to design the field-scale injection experiment and predict barrier longevity. For example, the sediment reduction rate influences the injection rate and lag time before extraction in the field experiment because the reduction rate controls the amount of time required for the dithionite solution to fully react with sediments. Sediment oxidation experiments were additionally conducted to determine the oxidation rate and provide a separate measure of the mass of reduced iron. Laboratory experiments that were used to meet these objectives included: 1) sediment reduction in batch (static) systems, 2) sediment reduction in 1-D columns, and 3) sediment oxidation in 1-D columns. Multiple reaction modeling was conducted to quantify the reactant masses and reaction rates.

The second objective of this study was to determine the pathway and rate(s) of TCE degradation by reduced Ft. Lewis sediment. Given the degradation rate, the thickness of the proposed reactive barrier can be designed. The degradation rate and pathway information was quantified in both batch and column experiments at different temperatures. Batch experiments provide the most complete pathway information, because data are not influenced by flow. However, complex geochemical rates have been shown to occur at somewhat different rates in columns relative to batch systems, due in part to a significantly higher sediment-to-water ratio and slower access to surface sites by mobile constituents (Szecsody et al. 1998a and 1998b). Therefore, degradation rate information from column experiments is generally considered more applicable to reactive transport at the field scale.

The creation of a reduced zone in the aquifer can affect the mobility of other metals, so the final objective of this study was to quantify iron and other heavy metal geochemical changes that occur. The changes in the mobility of heavy metals was addressed with column experiments and analysis of the effluent for the metals during sediment reduction and oxidation. Changes in surface iron geochemistry during reduction and oxidation were quantified because previous studies have shown that different $\mathrm{Fe}^{\mathrm{II}}$. phases produced by the dithionite treatment appear to have different reduction and oxidation rates. 



\subsection{Geochemical Reactions for Remediation of TCE}

\subsection{Iron Reduction Mechanism}

The remediation technology proposed for Ft. Lewis is based on the proven ability of reduced (ferrous) iron to abiotically degrade TCE and other organic contaminants (Roberts et al. 1996). The proposed technology utilizes existing iron in aquifer sediment that is chemically treated with a reductant (sodium dithionite buffered at high $\mathrm{pH}$ ) for a short time (typically $24 \mathrm{~h}$ to $60 \mathrm{~h}$ ) to reduce $\mathrm{Fe}^{\mathrm{III}}$-oxides present in the sediment to adsorbed or structural $\mathrm{Fe}^{\mathrm{II}}$ phases. This reduction process of aquifer sediments results in the groundwater redox conditions becoming reducing and the disappearance of dissolved oxygen in water, as conceptually shown in Figure 1 ( 0 to 0.1 years).

a)

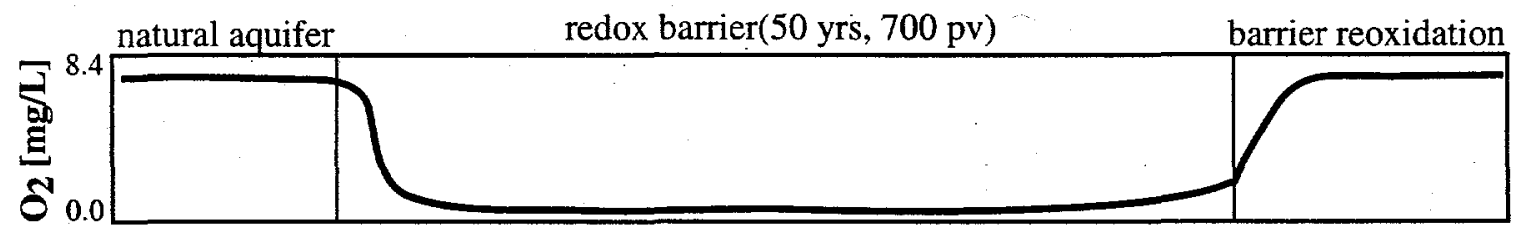

b)

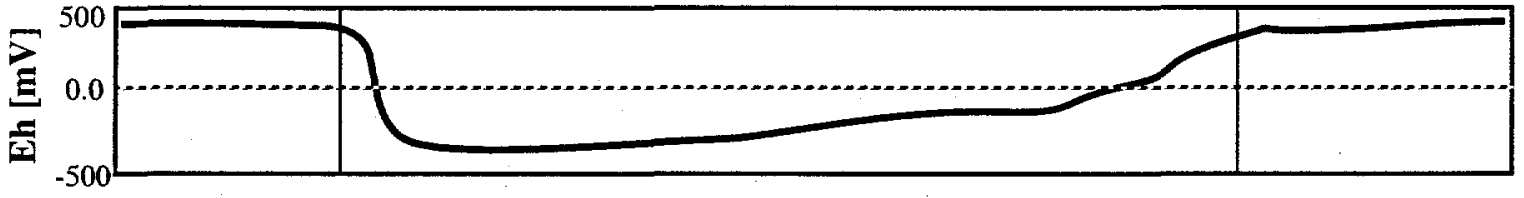

c)

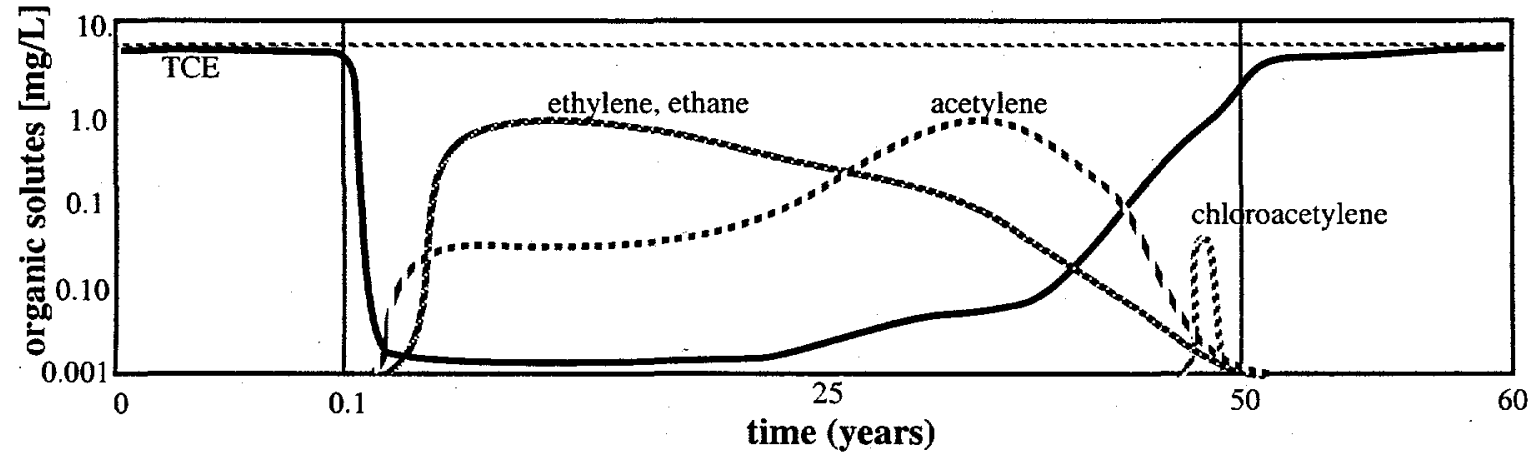

Figure 1. Conceptual diagram showing the influence of the redox barrier as a function of time on: a) dissolved oxygen in water which is the main barrier oxidant, b) the redox conditions of groundwater, and c) TCE and degradation products resulting from dechlorination by the reduced iron in the redox barrier.

The TCE dechlorination mechanism with reduced iron of this chemical treatment is generally the same as zero-valent permeable iron walls (conceptually shown in Figure 1c). Zero valent iron/mixed metal barriers also rely on the oxidation of ferrous (adsorbed or $\mathrm{Fe}^{\mathrm{II}}$ minerals such as green rust; Genin et al. 1998) to ferric iron as the electron donor for remediation of chlorinated aliphatic contaminants (Balko and Tratnyek 1998; Johnson et al. 1998) or reduction of metals such as chromate (Blowes et al. 1997; Buerge and Hug 1997), and not the oxidation of $\mathrm{Fe}^{0}$. Although aqueous $\mathrm{Fe}^{\mathrm{Il}}$ can 
reduce chromate (Eary and Rai 1988 ), adsorbed or structural $\mathrm{Fe}^{I I}$ on an $\mathrm{Fe}^{I I I}$-oxide, clay surface, or zero-valent iron surface is necessary for dechlorination reactions. The role of the surface is not clearly understood.

The dithionite chemical treatment dissolves and reduces amorphous and some crystalline $\mathrm{Fe}^{\mathrm{II}}$ oxides. The reduced $\mathrm{Fe}^{\mathrm{n}}$ created by the dithionite chemical treatment appears to be present in at least two different $\mathrm{Fe}^{\mathrm{II}}$ phases: adsorbed $\mathrm{Fe}^{\mathrm{II}}$ and $\mathrm{Fe}^{\mathrm{II}}$-carbonate (siderite). Adsorbed $\mathrm{Fe}^{\mathrm{II}}$ appears to be the dominant $\mathrm{Fe}^{\mathrm{II}}$ phase. There may be other, unidentified $\mathrm{Fe}^{\mathrm{II}}$ mineral phases produced. Although more than one $\mathrm{Fe}^{\text {III }}$ phase is likely reduced in a natural sediment, it can be useful to determine how simple a chemical model is needed to generally describe the observations. The reaction that describes a single phase of iron that is reduced by sodium dithionite:

$$
\mathrm{S}_{2} \mathrm{O}_{4}^{-2}+2 \equiv \mathrm{Fe}^{3+}+2 \mathrm{H}_{2} \mathrm{O} \Leftrightarrow=>2 \equiv \mathrm{Fe}^{2+}+2\left(\mathrm{SO}_{3}^{-2}\right)+4 \mathrm{H}^{+}
$$

shows that the forward rate is a function of the dithionite concentration and the square of the reducible iron concentration (rate is overall a third-order function of concentration). The aqueous $\mathrm{Fe}^{\mathrm{II}}$ produced has a high affinity for surfaces, so is quickly adsorbed. Therefore, $\mathrm{Fe}^{\mathrm{II}}$ mobility in mid- to high-pH, low ionic strength groundwater (i.e., Ft. Lewis groundwater) is extremely limited, and iron is not expected to leach from sediments during the dithionite treatment. Aqueous iron measurements in previous studies have shown $<1 \%$ iron leaching even after 600 pore volumes of groundwater through a sediment column. Corresponding solid iron measurements of sediments used in these columns showed $4 \%$ to $10 \%$ loss of iron. Iron mobility is somewhat higher during the actual dithionite injection, as a high ionic strength solution of other cations $\left(0.06 \mathrm{M} \mathrm{Na}^{+}\right.$and $0.24 \mathrm{M} \mathrm{K}^{+}$in this case) competes for the same adsorption sites as $\mathrm{Fe}^{2+}$, causing some $\mathrm{Fe}^{2+}$ desorption. Previous experimental transport studies with dithionite injection into sediments have shown $0 \%$ to $12 \%$ iron loss after 40 pore volumes of dithionite treatment.

Experimental evidence from previous studies with Hanford sediments (Istok et al. 1999; Fruchter et al. 2000) have shown that two parallel reduction reactions are needed to describe iron reduction data (i.e., a fraction of sites are quickly reduced and a fraction more slowly reduced). This may be the result of the reduction of two or more major $\mathrm{Fe}^{\mathrm{III}}$ phases. Based on this hypothesis, a second reduction reaction was added with a second ferric iron phase symbolized by $\equiv \equiv \mathrm{Fe}^{3+}$ :

$$
\mathrm{S}_{2} \mathrm{O}_{4}^{-2}+2 \equiv=\mathrm{Fe}^{3+}+2 \mathrm{H}_{2} \mathrm{O} \Leftrightarrow=\Rightarrow 2 \equiv \equiv \mathrm{Fe}^{2+}+2\left(\mathrm{SO}_{3}^{-2}\right)+4 \mathrm{H}^{+}
$$

The total number of oxidized or reduced iron sites is the sum of sites in reaction 1 and 2 . If the number of slowly reducing sites (Equation 2) is small, and the mass of iron is far in excess of the dithionite, reaction 1 can be reduced to a kinetic first-order reaction in which $\mathrm{Fe}^{3+}$ remains constant:

$$
\mathrm{S}_{2} \mathrm{O}_{4}^{-2} \Leftrightarrow=>\mathrm{Fe}^{2+}+\mathrm{SO}_{3}^{-2}
$$

Equation 3 is not a balanced reaction, but is meant to illustrate the species upon which the reaction rate is dependent. Other studies of this chemical treatment have shown that reactions 1 and 2 can be approximated in some cases with reaction 3 with a pseudo-first order rate of $\sim 5$ h (half-life). Another reaction occurs in the system, which describes the disproportionation of dithionite in contact with. sediment:

$$
2 \mathrm{~S}_{2} \mathrm{O}_{4}^{-2}+\mathrm{H}_{2} \mathrm{O} \Leftrightarrow \mathrm{S}_{2} \mathrm{O}_{3}^{-2}+2\left(\mathrm{HSO}_{3}^{-}\right)
$$

that accounts for the mass loss of dithionite that cannot be used for iron reduction. Other studies have shown that this reaction has a half-life of $\sim 27 \mathrm{~h}$ (basaltic sediments). The consequence of this 
reaction is to limit how slowly dithionite can be reacted with (i.e., injected into) sediment in the field. If dithionite is injected too slowly, a significant amount of its mass is lost to disproportionation.

Although $\mathrm{Fe}^{\mathrm{III}}$ phases are the most significant phases that react with dithionite, other mineral phases present in natural sediments may also be reduced and utilize some of the dithionite. Previous studies have shown that some Mn reduction occurs as a result of the dithionite treatment of Hanford sediment, although reduced $\mathrm{Mn}(\mathrm{II}, 0)$ phases were about $3.4 \%$ of the mass of reduced iron phases.

\subsection{Sediment Oxidation Mechanisms}

The oxidation of the adsorbed and structural $\mathrm{Fe}^{\mathrm{II}}$ in the sediments of the permeable redox barrier occurs naturally by the inflow of dissolved oxygen through the barrier, but can additionally be oxidized by contaminants that may be present such as chromate, TCE, nitrate, uranium, or other reducible species. If redox equilibrium completely defined the mechanism (i.e., no effects from activation energies), and contaminants are present in equal molar concentrations, they would be reduced faster in the following order:

$$
\text { chromate }>\text { dissolved oxygen }>\text { nitrate }>\text { uranium }>\text { TCE }
$$

In relatively uncontaminated aquifers, dissolved oxygen in water is the dominant oxidant of reduced iron species, as contaminants are generally present in lower molar concentrations relative to dissolved oxygen. The oxidation of reduced iron in pure mineral phases is described by the following reactions first by dissolved oxygen, then with other contaminants. $\mathrm{Fe}^{\mathrm{II}}$ species that are known to exist in the dithionite-reduced sediments include adsorbed $\mathrm{Fe}^{\mathrm{II}}$ and siderite $\left[\mathrm{Fe}^{\mathrm{II}} \mathrm{CO}_{3}\right]$. A single mole of electrons is consumed as a mole of these species is oxidized:

$$
\begin{aligned}
& \mathrm{Fe}^{2+}<=\Rightarrow \mathrm{Fe}^{3+}+e^{-} \quad \mathrm{Eh}=-0.77 \mathrm{v} \\
& \mathrm{Fe}^{2+}+3 \mathrm{H}_{2} \mathrm{O} \Leftrightarrow==\mathrm{Fe}(\mathrm{OH})_{3}(\mathrm{~s}) .+3 \mathrm{H}^{+}+e^{-} \mathrm{Eh}=-0.56 \mathrm{v} \\
& \mathrm{FeCO}_{3}(\mathrm{~s})+3 \mathrm{H}_{2} \mathrm{O} \Leftrightarrow \mathrm{Fe}(\mathrm{OH})_{3}(\mathrm{~s})+2 \mathrm{H}^{+}+\mathrm{HCO}_{3}^{-}+e^{-}
\end{aligned}
$$

The use of dissolved oxygen as an oxidant is generally divided into two electron sequences, and when combined, yields:

$$
\mathrm{O}_{2}+4 \mathrm{H}^{+}+4 e^{-} \quad \Leftrightarrow \quad \mathrm{H}_{2} \mathrm{O}, \quad \mathrm{Eh}=1.23 \mathrm{v}
$$

which shows that 4 moles of electrons are needed per mole of $\mathrm{O}_{2}$ consumed. The rate of this reaction (9) has generally been observed to be first-order at fixed $\mathrm{pH}$, and the rate increases 100 fold for a unit increase in $\mathrm{pH}$. Assuming one type of surface iron (adsorbed $\mathrm{Fe}^{\mathrm{II}}$ ) is oxidized by dissolved oxygen (reactions 5 and 8 ):

$$
4 \mathrm{Fe}^{2+}+\mathrm{O}_{2}+4 \mathrm{H}^{+} \Leftrightarrow 4 \mathrm{Fe}^{3+}+2 \mathrm{H}_{2} \mathrm{O} \quad \mathrm{Eh}=-1.85 \mathrm{v}
$$

yields 4 moles of $\mathrm{Fe}^{\mathrm{II}}$ are oxidized per mole of $\mathrm{O}_{2}$ consumed. At oxygen-saturated conditions (8.4 mg L $\mathrm{m}^{-1} \mathrm{O}_{2}, 1 \mathrm{~atm}, 25^{\circ} \mathrm{C}$ ), $1.05 \mathrm{mmol} \mathrm{\textrm {L } ^ { - 1 }} \mathrm{Fe}^{\mathrm{II}}$ is consumed. Experimental evidence indicates that the oxygenation of $\mathrm{Fe}^{\mathrm{II}}$ in solutions $(\mathrm{pH}>5)$ is generally found to be first order with respect to $\mathrm{Fe}^{\mathrm{II}}$ and $\mathrm{O}_{2}$ concentration and second-order with respect to $\mathrm{OH}-$. The rate of oxidation of $\mathrm{Fe}^{\mathrm{II}}$ in solution 
by oxygen at $\mathrm{pH} 8$ is a few minutes (Eary and Rai 1988, Buerge and Hug 1997). In contrast, the oxidation rate (as a half-life) observed in natural sediments (surface $\mathrm{Fe}^{\mathrm{II}}$ thought to be adsorbed $\mathrm{Fe}^{\mathrm{II}}$ and $\mathrm{Fe}^{\mathrm{II}} \mathrm{CO}_{3}$ ) was found to be $0.3 \mathrm{~h}$ to $1.1 \mathrm{~h}$.

The oxidation of reduced sediment appears to be more complex than can be described with a single oxidation reaction, and is likely controlled by both chemical and physical processes. Experimental evidence during iron oxidation experiments indicates that a second type of reduced iron species is present (siderite) in minor concentrations. In addition, a minor fraction of reduced iron sites (presumed to be siderite) appears to be more slowly oxidized, so a second oxidation reaction:

$$
4 \mathrm{FeCO}_{3}(\mathrm{~s})+\mathrm{O}_{2}+4 \mathrm{H}^{+} \Leftrightarrow 4 \mathrm{Fe}^{3+}+2 \mathrm{H}_{2} \mathrm{O}+4 \mathrm{CO}_{3}^{2-}
$$

was considered in the reaction model used. Both of these reactions (10 and 11) show that 4 moles of $\mathrm{Fe}^{\mathrm{II}}$ are consumed per mole of oxygen consumed. The $\mathrm{Fe}^{\mathrm{III}}$ produced in reactions (10) and (11) quickly precipitates as $\mathrm{Fe}(\mathrm{OH})_{3}$. The oxidation of redox barrier in an aquifer by dissolved oxygen is conceptually shown (Figure 1,0.1 years to 50 years), in which the Eh remains negative but slowly increases over the same time period of no dissolved oxygen breakthrough.

\subsection{TCE Degradation}

At the Ft. Lewis site, the abiotic degradation of TCE and other organic contaminants is being tested using the In Situ Redox Manipulation treatment technology. In this case, the organic contaminants are electron acceptors. The degradation pathway of TCE by dithionite-reduced sediment has been investigated in other studies as well as in Ft. Lewis sediments. Degradation pathways for most organic compounds including TCE are complex, involving multiple and potentially parallel reaction steps. Of four possible abiotic degradation pathways for TCE, the two considered most common are reductive elimination and hydrogenolysis. Reductive elimination has been shown to be the major pathway in other studies using zero-valent and ferrous iron (Sivavec et al. 1996; Orth and Gillham 1996). Reductive elimination reactions include (Roberts et al. 1996):

$$
\begin{array}{ll}
\mathrm{TCE}+2 \mathrm{e}^{-} \Leftrightarrow \text { chloroacetylene }+2 \mathrm{Cl} ; & \mathrm{Eh}=0.60 \mathrm{v} \\
\mathrm{PCE}-+2 \mathrm{e}^{-} \Leftrightarrow \text { dichloroacetylene }+2 \mathrm{Cl} ; & \mathrm{Eh}=0.63 \mathrm{v} \\
\text { cis-, trans-DCE }+2 \mathrm{e}-\Leftrightarrow \text { acetylene }+2 \mathrm{Cl}-; & \mathrm{Eh}=0.56 \mathrm{v}
\end{array}
$$

which describes the destruction of TCE and polychloroethylene (PCE) to easily degraded (abiotically or biotically) chlorinated acetylene products. Abiotic degradation of these products by hydrogenolysis:

$$
\begin{array}{ll}
\text { dichloroacetylene }+\mathrm{H}^{+}+2 \mathrm{e}^{-} \Leftrightarrow>\text { chloroacetylene }+\mathrm{Cl} ; & \mathrm{Eh}=0.56 \mathrm{v} \\
\text { chloroacetylene }+\mathrm{H}^{+}+2 \mathrm{e}^{-} \Leftrightarrow>\text { acetylene }+\mathrm{Cl}^{;} ; & \mathrm{Eh}=0.50 \mathrm{v} \\
\text { acetylene }+2 \mathrm{H}^{+}+2 \mathrm{e}^{-} \Leftrightarrow \text { ethylene; } & \mathrm{Eh}=0.39 \mathrm{v}
\end{array}
$$

apparently proceeds rapidly as chlorinated acetylenes are unstable (Delavarenne and Viehe 1969). The degradation of TCE to ethylene by reductive elimination (or hydrogenolysis discussed below) involves the production of 6 moles of electrons, or $22 \mathrm{mg} \mathrm{L}^{-1} \mathrm{TCE}$ needed to oxidize the equivalent mass of $\mathrm{Fe}^{l l}$ as water saturated with dissolved oxygen $\left(1.05 \mathrm{mmol} \mathrm{L}^{-1} \mathrm{Fe}^{\mathrm{II}}\right)$. Therefore, water containing partial oxygen saturation and $\sim 1.0 \mathrm{mg} \mathrm{L}^{-1} \mathrm{TCE}$ (as likely present in the Ft. Lewis aquifer with $0.3 \mathrm{mg} / \mathrm{L}$ in solution and $2 \mathrm{x}$ that mass adsorbed) means that TCE has an insignificant impact on $\mathrm{Fe}^{\mathrm{II}}$ oxidation and remediation barrier lifetime. In the event that the reduced iron barrier is exhausted, previous laboratory studies with the Hanford $100 \mathrm{D}$ and $100 \mathrm{H}$ sediment have shown that sediment can be re-reduced with only a small (5\% to $10 \%$ ) loss in capacity. Hydrogenolysis reactions include: 
which describes the degradation of TCE involving the production then destruction of dichloroethylene (DCE) and vinyl chloride intermediates (generally more difficult to degrade). These reduction potentials are lower than reductive elimination, indicating they are less likely to occur abiotically. Activation energies and the specific electron transfer mechanism, which does involve the $\mathrm{Fe}^{\text {III }}$ oxide surface, may also influence which reactions actually do occur. Studies of TCE degradation pathways using zero-valent iron and various $\mathrm{Fe}^{\mathrm{II}}$ minerals (Roberts et al. 1996; Sivavec and Horney 1995; Thornton et al. 1998) indicate that reductive elimination is the major pathway, with minor amounts of DCE isomers and vinyl chloride produced from the hydrogenolysis pathway. One study also indicates that the DCE isomers and vinyl chloride slowly degraded to ethylene.

The TCE reaction pathway can be used to model the observed rate of TCE degradation. Because acetylene is the main reaction product observed, the combination of reactions (6), (12), and (16) described the major TCE degradation pathway:

$$
\mathrm{TCE}+\mathrm{H}^{+}+4 \mathrm{Fe}^{2+} \Leftrightarrow \text { acetylene }+3 \mathrm{Cl}^{-}+4 \mathrm{Fe}^{3+}
$$

A set of differential mass flux equations for $(20)$ and (10) that describes iron oxidation by dissolved oxygen) for the 7 species can be written and simultaneously solved to define the rate of change of TCE. The mass flux equation for TCE:

$$
\partial \mathrm{TCE} / \partial \mathrm{t}=-\mathrm{k}_{\mathrm{f} 20}[\mathrm{TCE}]\left[\mathrm{H}^{+}\right]\left[\mathrm{Fe}^{2+}\right]^{4}+-\mathrm{k}_{\mathrm{b} 20}[\text { acetylene }]\left[\mathrm{Cl}^{-}\right]^{3}\left[\mathrm{Fe}^{3+}\right]^{4}
$$

describes mass fluxes as a function of each constituent concentration to each respective stoichiometric coefficient. The set of differential equations can be numerically solved (55 mixed equilibrium and kinetic reactions with 71 species described in Szecsody et al. [1995, 1998a, 1998b]), but this type of detailed modeling is useful only if extensive knowledge of the reaction parameters exists. In the case of TCE degradation, not enough information is known about the reaction pathways and reaction parameters to justify this approach.

Simpler models can be used to accurately describe the TCE degradation rate under specific conditions. The equation describing the TCE degradation rate can be greatly simplified assuming no backward mass flux and that the $\mathrm{pH}$ is buffered:

$$
\partial \mathrm{TCE} / \partial \mathrm{t}=-\mathrm{k}^{\prime}{ }_{\mathrm{r} 20}[\mathrm{TCE}]\left[\mathrm{Fe}^{2+}\right]^{4}
$$

which shows that the TCE degradation rate is a function of a rate coefficient $\left(k^{\prime}{ }_{20}\right)$, the TCE concentration, and the ferrous iron concentration (raised to a power $>1$ ). Therefore, as the sediment is slowly oxidized by both dissolved oxygen (reaction 10) and TCE (reaction 20), the observed overall TCE degradation rate $\left(\partial \mathrm{TCE}^{\prime} / \partial \mathrm{t}\right.$ ) will decrease. Over a small number of pore volumes, the $\mathrm{Fe}^{2+}$ concentration can be assumed constant, and the TCE degradation rate simplifies to a first-order reaction that can be integrated:

$$
\begin{aligned}
\partial \mathrm{TCE}{ }^{\prime \prime} / \partial \mathrm{t} & =-\mathrm{k}^{\prime \prime}{ }_{\mathrm{r} 20}[\mathrm{TCE}] \\
\mathrm{TCE} & =\operatorname{TCE}_{\mathrm{t}=0} \mathrm{e}^{-\lambda t}
\end{aligned}
$$

Both the pseudo-first-order approach (reaction 23) and the fixed-pH approach (numerical solution to reactions (10) and (22) were used in this study to describe the TCE degradation data). As stated 
earlier, because the actual TCE degradation rate is a function of $\mathrm{Fe}^{2+}$ and decreases over time, the firstorder half-life will appear to decrease at progressively later points in time. As the overall TCE degradation rate decreases, the relative concentrations of degradation products change (Figure 1) during flow through a redox barrier in an aquifer. In general, final degradation products (ethylene, ethane) appear when all reactions are occurring at the fastest rates, and as reactions slow, intermediates (acetylene) and finally the initial degradation product of TCE dechlorination (chloroacetylene) appears.

\subsection{Partial Iron Reduction and Temperature Effects on TCE Degradation}

The electron-transfer mechanisms of TCE dechlorination by surface $\mathrm{Fe}^{\mathrm{Il}}$ phases are not completely understood, and as a consequence, there is a lack of ability to predict the TCE degradation rate with sediment that is only partially reduced. Two aspects of the electron transfer reactions are known: abiotic dechlorination of TCE and other chlorinated organic compounds requires both available $\mathrm{Fe}^{\mathrm{II}}$ as an electron donor and the presence of an iron oxide or zero-valent iron surface. The surface is necessary for the electron transfer reaction as laboratory experiments have shown that TCE and carbon tetrachloride are not dechlorinated in the presence of only aqueous $\mathrm{Fe}^{\mathrm{II}}$. The role of the surface is not well understood, although may act as a catalyst, a semiconductor, or provide the necessary surface coordination for the electron transfer reactions (Scherer et al. 1999; Wehrli 1992).

The potential role of surface coordination of adsorbed $\mathrm{Fe}^{\mathrm{II}}$ on the iron reduction/TCE dechlorination reaction is illustrated with an idealized example. The TCE dechlorination reaction is a twoelectron transfer reaction in a single step (described in Section 2.4), so it is hypothesized that two adsorbed $\mathrm{Fe}^{\text {II }}$ molecules that are adjacent are needed for this reaction to occur. Assuming a single $\mathrm{Fe}^{\mathrm{III}}$ oxide (goethite) that has orthorhombic crystal structure, adsorption sites are located in a rectangular grid, so a single site has 8 possible adjacent adsorption sites. The relationship between fraction of surface coverage of $\mathrm{Fe}^{\mathrm{II}}$ on a goethite surface and the fraction of paired sites was developed from probability theory and verified with numerical simulations using a 200 by 200 grid of sites (Figure 1). The number of adjacent adsorbed $\mathrm{Fe}^{\mathrm{II}}$ sites is a fraction of the number adsorbed sites at low surface coverage. For example, if $50 \%$ of the surfaces are occupied by $\mathrm{Fe}^{\mathrm{II}}$, only $25.2 \%$ of the sites are adjacent (solid line) and could promote TCE dechlorination. The implication of this surface area hypothesis is that partially reduced sediment will be significantly less effective at dechlorinating TCE than would be predicted assuming a linear relationship between fraction reduction and TCE dechlorination rate (dashed line, Figure 1).

The role of the iron oxide surface on TCE dechlorination was also experimentally investigated by developing a relationship between fraction-reduced iron and the resulting dechlorination ability of the sediment. In these experiments, sediment was reduced in batch systems and the mass of reduced iron measured by different types of iron extractions including oxygen breakthrough in columns. Batch time-course experiments were used to determine the resulting TCE dechlorination rate.

The potential role of the iron oxide surface as a catalyst for TCE dechlorination was investigated by batch TCE dechlorination time-course experiments over a temperature range. In contrast to a simple chemical reaction, a chemical reaction that requires a surface catalyst will likely show a more complex relationship between reaction rate and temperature, because the catalyst may cease to function as the temperature decreases beyond a specific value. 
Iron reduction experiments were investigated over a temperature range to determine if the relative rates of iron reduction and disproportionation changed. Field-scale reductions take place at temperatures lower than laboratory studies, and these rate data are needed to design field-scale injection strategies. The ambient temperature of the Ft. Lewis aquifer is unusually cold at $11^{\circ} \mathrm{C}$ to $12^{\circ} \mathrm{C}$ (compared with many aquifers in the $16^{\circ} \mathrm{C}$ to $19^{\circ} \mathrm{C}$ range), and the time needed for reduction to be completed at $11^{\circ} \mathrm{C}$ results in additional density effects of the injection solution. Additional field-scale reductions will occur with the injection of heated water so that reduction occurs more quickly at higher temperature $\left(20^{\circ} \mathrm{C}\right.$ to $\left.22^{\circ} \mathrm{C}\right)$, where density effects of the injection fluid are minimized. At $25^{\circ} \mathrm{C}$, iron reduction has a $\sim 5 \mathrm{~h}$ half-life and disproportionation a $27 \mathrm{~h}$ half-life. The rate at which a chemical reaction proceeds is a linear function, and will generally decrease in rate $2 x-3 x$ for each $10^{\circ} \mathrm{C}$ decrease. Because these two reactions are simple chemical reactions, it is expected that their relative rates would remain proportionally separated. 


\subsection{Experimental and Modeling Methods}

\subsection{Batch and Column Experiments}

A series of batch and column experiments were conducted to determine the mass and rate of reduction of iron in sediment by the reduction solution (sodium dithionite $\mathrm{pH}$ buffered to 11.0). The batch experiments consisted of a single large septa-top glass bottle in which $14 \mathrm{~g}$ to $200 \mathrm{~g}$ of sediment was mixed with the dithionite solution for hundreds of hours. The experiment is then mixed on a linear shaker at slow rpm (to not cause particles to break up) and placed in a temperaturecontrolled chamber $\left(2^{\circ} \mathrm{C}\right.$ to $\left.42^{\circ} \mathrm{C}\right)$ for the 10 different batch reduction experiments conducted (Table 1). At specific time intervals (minutes to tens of hours, a sample was withdrawn, filtered, and analyzed for dithionite remaining in solution. It is assumed that the sample volume withdrawn $(0.2 \mathrm{~mL})$ was small to the total system volume, and so the sampling did not affect the experimental conditions. The dithionite solution contained $0.001 \mathrm{~mol} \mathrm{~L}^{-1}$ to $0.10 \mathrm{~mol} \mathrm{~L}-1$ sodium dithionite $\left(\mathrm{Na}_{2} \mathrm{~S}_{2} \mathrm{O}_{4}\right)$, with $4 \mathrm{x}$ the dithionite concentration $\mathrm{K}_{2} \mathrm{CO}_{3}$, and $0.4 \mathrm{x} \mathrm{KHCO}_{3}$. These batch experiments were conducted inside an anaerobic chamber to prevent the dithionite from reacting with oxygen. The dithionite concentration was measured by UV absorption at $315 \mathrm{~nm}$, as described below.

Sediment reduction studies conducted in 1-D columns consisted of injecting the dithionite solution at a steady rate into a sediment column and measuring the concentration of dithionite over time in the effluent for $48 \mathrm{~h}$ to $100 \mathrm{~h}$ (Table 2; 23 column reduction experiments). The flux rate was chosen to achieve specific residence times of the dithionite solution in the column ( $2 \mathrm{~h}$ to $14 \mathrm{~h})$ relative to the reaction rates (Szecsody and Bales 1989). Column experiments involved measuring additional parameters to interpret dithionite results. The dry bulk density and porosity of the column was calculated from the dry and saturated column weight and column volume. The volumetric flow rate was calculated from the effluent volume and elapsed time. The electrical conductivity of the column effluent provided a second (dynamic) measure of the porosity, and was measured using a flow-through electrode and automatic data logging.

The dithionite concentration in the effluent was measured once per hour using an automated fluid system and data logging equipment. These measurements were taken with an HPLC injection valve with $15 \mu \mathrm{L}$ to $52 \mu \mathrm{L}$ loop that isolated a specified volume of the effluent. The contents of the loop were mixed with $5 \mathrm{~mL}$ to $10 \mathrm{~mL}$ of oxygen-free water, then injected into a UV-detector and absorbance measured at $315 \mathrm{~nm}$. The sample injection took 2 minutes to flow the complete sample through the detector, and the absorbance over a 1-minute interval was averaged for a single dithionite

concentration measurement. A triple-wash between injections prevented sample overlap. These fluid operations were controlled from one computer, and the dithionite concentration logged on a second computer. The concentration of the dithionite influent was measured with the same automated system by manually bypassing the column at approximately $24 \mathrm{~h}$ intervals over the multi-day experiments (Williams and Szecsody 1997). The fraction of reduced iron was calculated from dithionite breakthrough curves by determining the total mass loss (i.e., dithionite mass injected minus dithionite in the effluent) and the mass of dithionite used for disproportionation. The remaining dithionite mass loss was used for iron reduction. This dithionite breakthrough analysis assumes that dithionite has reached a steady state mass loss due to disproportionation and that all the iron has been reduced. The rate of iron reduction is also calculated from the steady state dithionite concentration during initial breakthrough (i.e., before the iron is all reduced). 
Table 1. Summary of batch reduction experiments

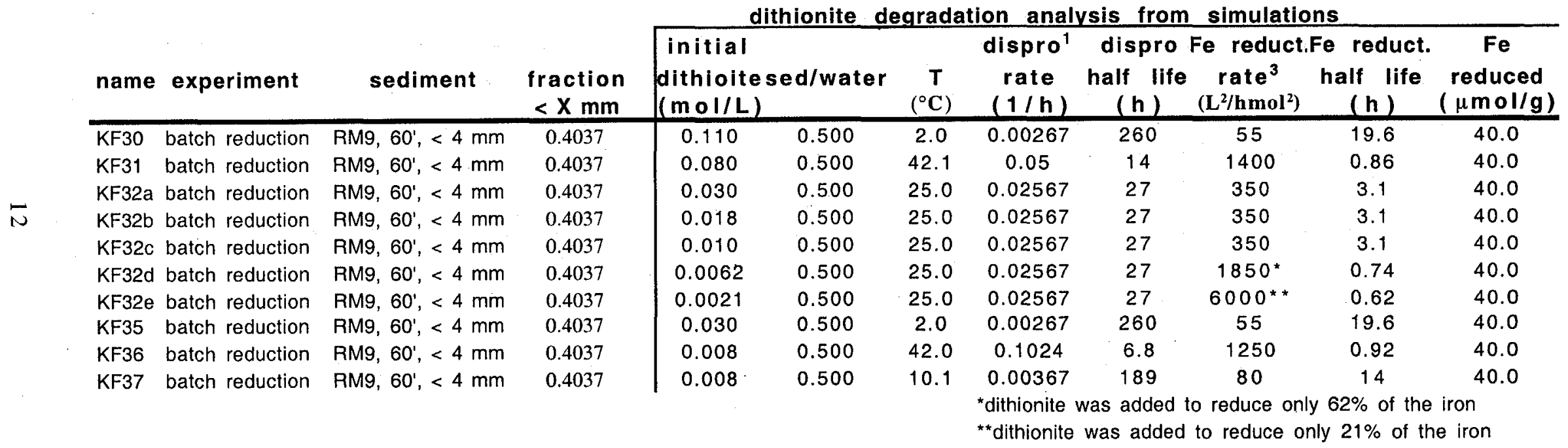


Table 2. Summary of reduction and oxidation column experiments

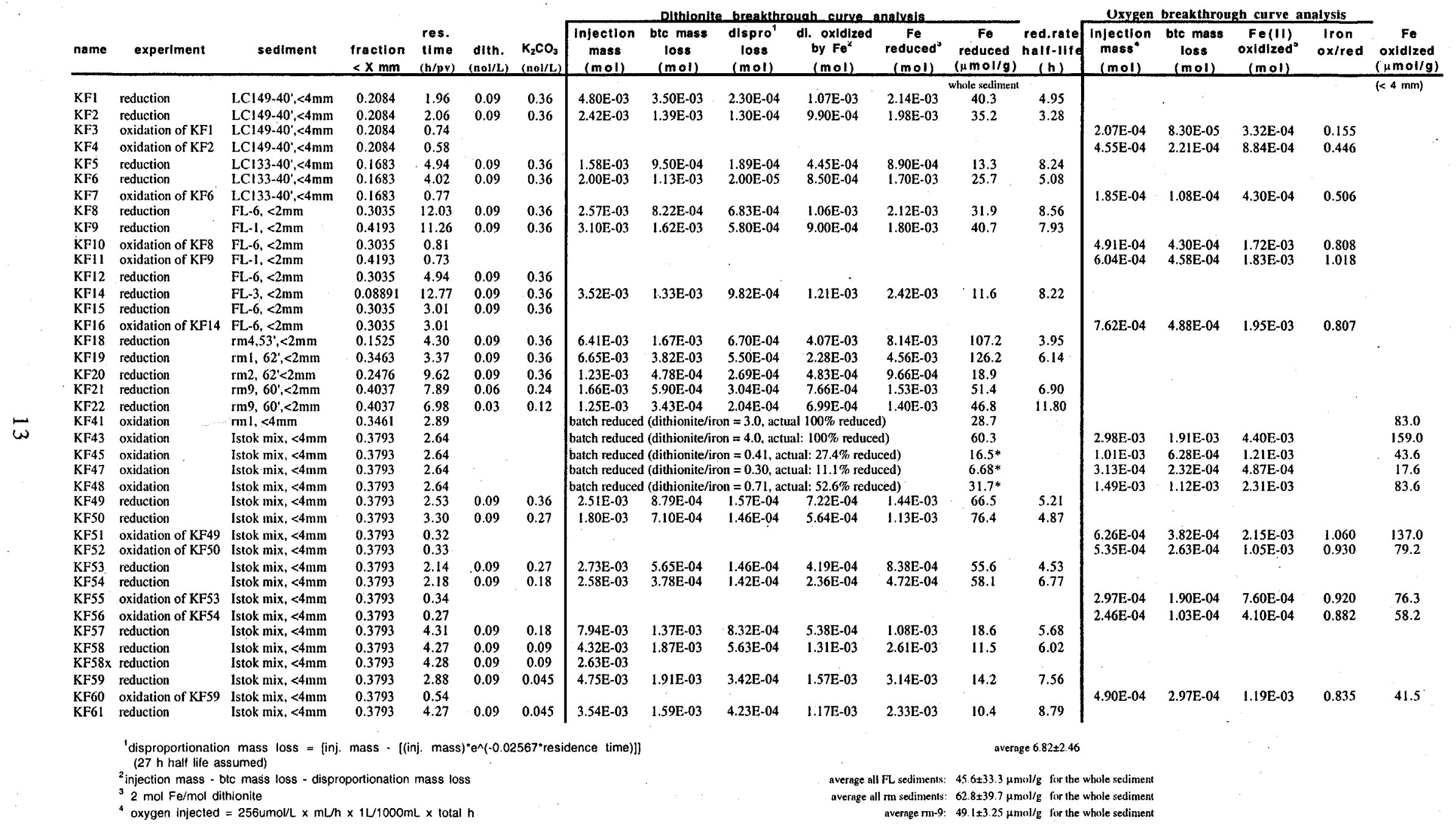


Sediment oxidation studies were also conducted in 1-D columns to determine the rate at which the dithionite-reduced sediments are oxidized and to provide an additional measure of the mass of reduced iron. These experiments (Table 2; 16 experiments) consisted of injecting oxygen-saturated $\left(8.4 \mathrm{mg} / \mathrm{L}^{-1}\right)$ water at a steady rate into a reduced sediment column and measuring the concentration of dissolved oxygen over time in the effluent for $100 \mathrm{~h}$ to $800 \mathrm{~h}$. The flux rate was chosen to achieve specific residence times of the dissolved oxygen in the column relative to the oxidation rate(s) of the sediment. The water used in experiments approximated the major ions found in the aquifer (consisting of $15 \mathrm{mg} / \mathrm{L} \mathrm{NaCl}, 8.2 \mathrm{mg} / \mathrm{L} \mathrm{KCl}, 67 \mathrm{mg} / \mathrm{L} \mathrm{CaSO}{ }_{4}, 13 \mathrm{mg} / \mathrm{L} \mathrm{MgCO}_{3}, 150 \mathrm{mg} / \mathrm{L} \mathrm{CaCO}{ }_{3}, 15.3 \mathrm{mg} / \mathrm{L}$ $\mathrm{H}_{2} \mathrm{SiO}_{3}$, and the $\mathrm{pH}$ adjusted to 7.7 to 8.2 ). A series of in-line micro-electrodes were used to monitor geochemical changes during oxidation and included dissolved oxygen ( 2 electrodes), $\mathrm{Eh}, \mathrm{pH}$, and electrical conductivity. Electrode measurements were continuously monitored, averaged, and data logged at 2-minute to 5-minute intervals. Two point calibration was conducted on the in-line electrodes at $4 \mathrm{~h}$ to $8 \mathrm{~h}$ intervals (oxygen-free and oxygen-saturated solution for oxygen) using an automated fluid system. Electrode data from calibrations were also data logged. The mass of reduced iron that was oxidized was calculated from the oxygen breakthrough curves. The difference in the total mass of dissolved oxygen injected minus dissolved oxygen in the effluent is that consumed by ferrous iron. This oxygen breakthrough analysis assumes dynamic equilibrium, or that all of the reduced iron has been oxidized in the column. In many cases, there is a fraction of the sediment that has not been oxidized, so some error in estimating the fraction not reduced is introduced.

Additional analysis was conducted on sediment and water samples to establish additional information about the redox geochemistry of the Ft. Lewis sediment during reduction and oxidation cycling. To establish the mobility of trace metals during sediment reduction and oxidation, liquid effluent samples from some column reduction experiments and oxidation experiments were analyzed for trace metals by ICP-MS. Geochemical analysis of sediment samples was conducted to determine the amounts of various $\mathrm{Fe}^{\text {IIIIII }}$ phases, which included seven different types of iron extractions (Heron and Christensen 1995; Chao and Zhou 1983; Heron et al. 1994a,b).

The TCE and other organic contaminant degradation studies were conducted in batch systems and in 1-D columns. Batch TCE experiments consisted of reacting Ft. Lewis groundwater containing $1 \mathrm{ppm}$ to $2 \mathrm{ppm}$ TCE with reduced Ft. Lewis sediment in individual vials with no headspace for times from minutes to $240 \mathrm{~h}$ (Table 3, 22 experiments). Water was then extracted and organic solutes analyzed by gas chromatograph (GC) or gas chromatograph mass spectrometry (GC-MS). To more clearly discriminate the reaction pathway of TCE, in some batch studies deionized water containing only TCE was reacted with reduced sediment. This eliminated the effects of reaction products of PCE, TCA, and DCE interfering with determining the masses of TCE degradation products. All batch TCE experimental vials were placed on low rpm rotary mixers and placed in chambers $\left(2{ }^{\circ} \mathrm{C}\right.$ to $\left.42^{\circ} \mathrm{C}\right)$ for temperature studies. Water and sediment for these temperature studies were pre-equilibrated at the appropriate temperature before the experiment started. Sediment reduction was generally accomplished in columns to control the amount of reduction. Mixing of the sediment, water, and TCE was accomplished in an anaerobic chamber to minimize the oxidation of ferrous iron by atmospheric oxygen.

Column experiments consisted of injecting Ft. Lewis groundwater into reduced Ft. Lewis sediment at a steady flow rate and collecting effluent water for measurement of degradation products. As with other column studies discussed, the flow rate was chosen to achieve specific residence times that would be similar to the TCE degradation rate ( $5 \mathrm{~h}$ to $50 \mathrm{~h}$ range). Seven TCE column experiments were conducted with residence times ranging from $5.8 \mathrm{~h}$ to $102 \mathrm{~h}$ (Table 4 ). Most experiments were initiated with $100 \%$ reduced sediment. Because the degradation rate was expected to slow as the sediment was oxidized, in one column, the TCE degradation rate was additionally measured at 100 and 230 to pore volumes after oxygen-saturated water was flushed through the column to partially 
Table 3. Summary of batch TCE experiments

\begin{tabular}{|c|c|c|c|c|c|c|c|c|c|c|c|c|c|c|c|c|c|}
\hline \multirow[b]{2}{*}{ name } & \multirow[b]{2}{*}{ sediment } & \multirow[b]{2}{*}{$\begin{array}{l}\text { fraction } \\
<\times \mathrm{mm}\end{array}$} & \multirow[b]{2}{*}{ reduction } & \multirow[b]{2}{*}{$\begin{array}{c}\text { water } \\
\text { source }\end{array}$} & \multirow[b]{2}{*}{ 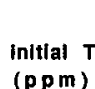 } & \multirow[b]{2}{*}{$\begin{array}{l}\text { CE conc. } \\
(\mu \mathrm{mol} / \mathrm{L})\end{array}$} & \multirow[b]{2}{*}{$\begin{array}{c}\boldsymbol{T} \\
\left({ }^{\circ} \mathrm{C}\right)\end{array}$} & \multicolumn{2}{|c|}{ adsorption } & \multirow{2}{*}{$\begin{array}{l}\text { total TCE } \\
\text { removed } \\
\text { (fraction) }\end{array}$} & \multirow{2}{*}{$\begin{array}{l}\text { acetylene } \\
\text { generated } \\
\text { (fraction) }\end{array}$} & \multicolumn{4}{|c|}{ TCE dechlorination rate } & \multirow[b]{2}{*}{$\begin{array}{l}\text { degradation } \\
\text { products }\end{array}$} & \multirow[b]{2}{*}{$\begin{array}{c}\text { other } \\
\text { compounds }\end{array}$} \\
\hline & & & & & & & & $\left(\mathrm{cm}^{3} / \mathrm{g}\right)$ & $\begin{array}{l}\text { TCE rem. } \\
\text { by ads. }\end{array}$ & & & $\begin{array}{l}\text { rate:t } \\
(1 / \mathbf{h}))\end{array}$ & $\begin{array}{l}\text { half life } \\
\text { (h) }\end{array}$ & analysis & $\begin{array}{c}\# \\
\text { points }\end{array}$ & & \\
\hline$\overline{\text { KF13 }}$ & FL6 $<2 \mathrm{~mm}$ & 0.3035 & $100 \%$ reduced & Ft.L groundwater & 2.700 & 20.50 & 25.0 & 0.53 & 0.21 & 0.995 & & 0.200 & 3.46 & GC-MS & 22 & c.acet., acet, eth. I & DCE, vinylchloride \\
\hline KF24 & $\mathrm{RM} 9,60^{\prime},<4 \mathrm{~mm}$ & 0.4037 & $100 \%$ reduced & Ft .L groundwater & 1.005 & 7.66 & 23.8 & 1.13 & 0.36 & 0.96 & & 0.144 & 4.8 & GC-MS & 7 & acetylene & vinyl chloride \\
\hline KF25 & $\mathrm{RM} 9,60^{\circ},<4 \mathrm{~mm}$ & 0.4037 & $100 \%$ reduced & Ft.L groundwater & 0.836 & 6.25 & 17.1 & 0.94 & 0.32 & 0.56 & & 0.050 & 13.9 & GC-MS & 7 & acetylene & vinyl chloride \\
\hline KF26 & $\mathrm{RM} 9,60^{\prime},<4 \mathrm{~mm}$ & 0.4037 & $100 \%$ reduced & Ft .L groundwater & 1.080 & 8.22 & 10.0 & 0.97 & 0.33 & 0.86 & & 0.030 & 23.1 & GC-MS & 7 & acetylene & vinyl chloride \\
\hline KF33 & RM9, $60^{\circ},<4 \mathrm{~mm}$ & $0.4037^{\circ}$ & $100 \%$ reduced & Ft L L groundwater & 1.320 & 10.08 & 2.5 & 1.03 & 0.34 & 0.56 & & 0.005 & 140 & GC-MS & 7 & acetylene & vinyl chloride \\
\hline KF34 & $\mathrm{RM} 9,60^{\circ},<4 \mathrm{~mm}$ & 0.4037 & $100 \%$ reduced & Ft L groundwater & 2.150 & 16.41 & 42.0 & 0.82 & 0.29 & 0.70 & & 0.050 & 13.9 & GC-MS & 7 & acetylene & vinyl chloride \\
\hline KF40a & $\mathrm{RM} 9,60^{\circ},<4 \mathrm{~mm}$ & 0.4037 & reduced $(0.82)^{*}$ & TCE in di water & 1.760 & 13.41 & 25.0 & 0.90 & 0.31 & 0.62 & & 0.0062 & 110 & GC & 3 & acetylene & \\
\hline $\mathrm{KF} 40 \mathrm{~b}$ & $\mathrm{RM} 9,60^{\circ},<4 \mathrm{~mm}$ & 0.4037 & reduced $(0.65)^{*}$ & FCE in di water & 1.760 & 13.41 & 25.0 & - & & 0.49 & & 0.0047 & 147 & GC & 3 & acetylene & \\
\hline $\mathrm{KF} 40 \mathrm{c}$ & $\mathrm{RM} 9,60^{\circ},<4 \mathrm{~mm}$ & 0.4037 & reduced $(0.49)^{*}$ & TCE in di water & 1.760 & 13.41 & 25.0 & - & & 0.71 & & 0.00044 & 1400 & GC & 3 & acetylene & \\
\hline KF40d & $\mathrm{RM} 9,60^{\circ},<4 \mathrm{~mm}$ & 0.4037 & reduced $(0.33)^{*}$ & TCE in di watter & 1.760 & 13.41 & 25.0 & - & & 0.62 & & 0.00008 & $>2000$ & GC & 3 & acetylene & \\
\hline KF40e & $\mathrm{RM} 9,60^{\circ},<4 \mathrm{~mm}$ & 0.4037 & reduced $(0.16)^{*}$ & TCE in di water & 1.760 & 13.41 & 25.0 & - & & 0.63 & & none & - & GC & 3 & acetylene & \\
\hline $\mathrm{KF} 42 \mathrm{a}$ & $\mathrm{RM1}, 60^{\prime},<4 \mathrm{~mm}$ & 0.3875 & $100 \%$ reduced & rCE in di water & 1.540 & 11.76 & 25.0 & 1.123 & 0.36 & 0.89 & 0.825 & 0.161 & 4.3 & GC & 8 & acetylene & \\
\hline $\mathrm{KF} 42 \mathrm{~b}$ & Istok mix, $<4 \mathrm{~mm}$ & 0.3793 & $4.0 \%$ reduced & TCE in di water & 1.041 & 7.92 & 25.0 & 5.512 & 0.73 & 0.42 & 0.000 & none & .- & GC & 5 & acetylene & \\
\hline $\mathrm{KF} 42 \mathrm{c}$ & Istok mix, $<4 \mathrm{~mm}$ & 0.3793 & $11.1 \%$ reduced & TCE in di water & 1.270 & 9.67 & 25.0 & 5.512 & 0.73 & 0.45 & 0.017 & 0.0006 & 1100 & GC & 5 & acetylene & \\
\hline KF42d & Istok mix, $<4 \mathrm{~mm}$ & 0.3793 & $27.4 \%$ reduced & TCE in di water & 1.041 & 7.92 & 25.0 & 5.512 & 0.73 & 0.61 & 0.167 & 0.0028 & 250 & GC & 5 & acetylene & \\
\hline $\mathrm{KF} 42 \mathrm{e}$ & Istok mix, $<4 \mathrm{~mm}$ & 0.3793 & $27.4 \%$ reduced & TCE in di water & 2.000 & 15.2 & 25.0 & 5.512 & 0.73 & 0.53 & 0.056 & 0.0032 & 216 & GC & 4 & acetylene & \\
\hline KF42f & Istok mix, $<4 \mathrm{~mm}$ & 0.3793 & $33.4 \%$ reduced & TCE in di water & 1.270 & 9.67 & 25.0 & 5.512 & 0.73 & 0.70 & 0.204 & 0.0058 & 120 & GC & 5 & acetylene & \\
\hline $\mathrm{KF} 42 \mathrm{~g}$ & Istok $\mathrm{mix},<4 \mathrm{~mm}$ & 0.3793 & $38.7 \%$ reduced & TCE in di water & 2.000 & 15.2 & 25.0 & 5.512 & 0.73 & 0.54 . & 0.091 & 0.0107 & 65 & GC & 4 & acetylene & \\
\hline $\mathrm{KF} 42 \mathrm{~h}$ & Istok mix, $<4 \mathrm{~mm}$ & 0.3793 & $38.7 \%$ reduced & TCE in di water & 2.000 & 15.2 & 25.0 & 5.512 & 0.73 & 0.4 & & 0.0139 & 50 & GC & 2 & acetylene & \\
\hline KF42i & Istok mix, $<4 \mathrm{~mm}$ & 0.3793 & $43.8 \%$ reduced & TCE in di water & 1.041 & 7.92 & 25.0 & 5.512 & 0.73 & 0.91 & 0.911 & 0.036 & 19.2 & GC & 5 & acetylene & \\
\hline $\mathrm{KF} 42 \mathrm{j}$ & Istok $\mathrm{mix},<4 \mathrm{~mm}$ & 0.3793 & $52.6 \%$ reduced & TCE in di water & 1.270 & 9.67 & 25.0 & 5.512 & 0.73 & 0.95 & 0.594 & 0.043 & 16 & GC & 5 & acetylene & \\
\hline $\mathrm{KF} 42 \mathrm{k}$ & Istok mix, $<4 \mathrm{~mm}$ & 0.3793 & $100 \%$ reduced & TCE in di water & 0.813 & 6.19 & 25.0 & 5.512 , & 0.73 & 0.999 & 0.750 & 0.578 & 1.2 & GC & 3 & acetylene & \\
\hline KF62a & Istok mix, $<4 \mathrm{~mm}$ & 0.3793 & $0.09 \mathrm{M}$ buffer & TCE in di water & 12.100 & 90.5 & 25.0 & 5.512 & 0.73 & 0.55 & 0.069 & 0.043 & 200 & GC & 4 & acetylene & \\
\hline KF62b & Istok mix, $<4 \mathrm{~mm}$ & 0.3793 & $0.045 \mathrm{M}$ buffer & TCE in di water & 12.100 & 90.5 & 25.0 & 5.512 & 0.73 & 0.490 & 0.012 & 0.0005 & 1400 & GC & 4 & acetylene & \\
\hline
\end{tabular}

Table 4. Summary of TCE column experiments

\begin{tabular}{|c|c|c|c|c|c|c|c|c|c|c|c|c|c|c|c|c|c|c|c|c|}
\hline name & sediment & fraction & reduction & $\begin{array}{l}\text { res. } \\
\text { time }\end{array}$ & $\begin{array}{l}\text { total } \\
\text { time }\end{array}$ & pore vol. & & Intilial $T$ & TCE conc. & $T$ & $\frac{\text { adsor }}{\mathrm{Kd}}$ & Pptlon & $\begin{array}{l}\text { total TCE } \\
\text { removeded }\end{array}$ & $\begin{array}{l}\text { acotylene } \\
\text { generated }\end{array}$ & $\frac{\text { TCE }}{\text { Trte }}$ & $\begin{array}{l}\text { E dechlo } \\
\text { half Iif }\end{array}$ & $\frac{\text { Ination rate }}{\text { onalysis }}$ & & & other \\
\hline Mane & & $<x \mathrm{~mm}$ & & & & & source & $(p \min )$ & & ( $2 \mathrm{C})$ & & & & 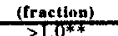 & & & & pointe & $\begin{array}{l}\text { products } \\
\text { cacet acet eth }\end{array}$ & $\begin{array}{l}\text { compounds } \\
\text { TCEE Sing chloride }\end{array}$ \\
\hline KAT7a & FLO $<2 \mathrm{~mm}$ & 0.3035 & $700 \%$ reduced & 73 & & $0-3$ & Ff.L groutndwater & 0.571 & 4.36 & 25.0 & & $3.5 \mathrm{pv}$ & 0.982 & $>1.0^{* * *}$ & & 88 & GC-MS & & c.acet., acet, eth. & DCE, vinyl chlonide \\
\hline KFI7b & $F L 6<2 \mathrm{~mm}$ & 0.3035 & $80 \%$, reduced & 67 & $427-622$ & $\begin{array}{l}102-105 \\
230-234\end{array}$ & $\begin{array}{l}\text { Ft.L groundwater } \\
\text { FF L proumdwater }\end{array}$ & 1.200 & 9.10 & 25.0 & 0.53 & $3.5 \mathrm{pv}$ & 0.92 & $>1.0 * *$ & 0.036 & 19 & GC-MS & 5 & c.acet., acet, eth. & DCE, vinyl chlonide \\
\hline KFI7c & FL $6<2 \mathrm{~mm}$ & 0.3035 & $55 \%$ reduced & 102 & 808-1055 & $230-234$ & & 1.490 & $\begin{array}{ll}11.35 \\
1554\end{array}$ & 25.0 & 0.53 & $3.5 \mathrm{pv}$ & 0.80 & 1.000 & 0.025 & 28 & GC-MS & 6 & c.acet., acet, eth. & DCE. vinyl chloride \\
\hline KF I7d & FL6 $<2 \mathrm{~mm}$ & 0.3035 & $50 \%$ reduced & 83 & $1100-1400$ & 234.238 & Ft.L groundwater & 2.040 & 15.53 & 25.0 & 0.53 & $3.5 \mathrm{pv}$ & 0.40 & 1.000 & 0.080 & 88 & GC-MS & 4 & c.acet., acet, eth. & DCE, vinyl chloride \\
\hline KF23 & $\begin{array}{l}R M 9<4 \mathrm{~mm} \\
R M 9<4 \mathrm{~mm}\end{array}$ & 0.4037 & $\begin{array}{l}100 \% \text { reduced } \\
105 \% \text { reduced }\end{array}$ & 5.8 & $\begin{array}{l}0.216 \\
0.380\end{array}$ & $\begin{array}{l}0.37 \\
0.35\end{array}$ & Ft.L. groundwater & 3.090 & $\begin{array}{l}23.51 \\
7.24\end{array}$ & $\begin{array}{l}25.0 \\
10.0\end{array}$ & 0.90 & $\begin{array}{l}6.1 \mathrm{pv} \\
5.2 \mathrm{pv}\end{array}$ & $\begin{array}{l}0.85 \\
0.45\end{array}$ & $\begin{array}{l}\text { not meas. } \\
0.000\end{array}$ & $\begin{array}{l}0.025 \\
0.039\end{array}$ & $\begin{array}{l}28 \\
18\end{array}$ & $\begin{array}{l}\text { GC-MS } \\
\text { GC }\end{array}$ & $\begin{array}{l}4 \\
8\end{array}$ & & $\begin{array}{l}\text { I,IDCE, I, DCE, TCA* } \\
\text { DCE }\end{array}$ \\
\hline $\begin{array}{l}\text { KF38 } \\
\text { KF39 }\end{array}$ & RM9 <4inm & & $-25 \%$ reduced & 10.7 & & $\begin{array}{l}0.35 \\
0.35\end{array}$ & Ft. L groundwater & 0.951 & 7.24 & $\begin{array}{l}10.0 \\
10.0\end{array}$ & 0.966 & $\begin{array}{l}5.2 \mathrm{pv} \\
5.2 \mathrm{pv}\end{array}$ & 0.45 & $\begin{array}{l}0.000 \\
0.007\end{array}$ & $\begin{array}{r}0.039 \\
0.0140\end{array}$ & $\begin{array}{l}18 \\
51\end{array}$ & ${ }_{\mathrm{GC}}^{\mathrm{GC}}$ & $\begin{array}{l}8 \\
8\end{array}$ & $\begin{array}{l}\text { cactylene } \\
\text { acetylene }\end{array}$ & $\begin{array}{l}\text { DCE } \\
\text { DCE }\end{array}$ \\
\hline KF39 & RM9 $<4$ minn & 0.4037 & $(1 / 4)(1007 \%$ redured & 12.4 & 0.380 & & & & & & & & & & & & & & & \\
\hline
\end{tabular}


oxidize the sediment. The sediment was expected to remain anoxic for $\sim 450$ pore volumes. Two experiments were conducted with $25 \%$ reduced sediment and additionally at $10^{\circ} \mathrm{C}$ to be similar to field-scale conditions of early dithionite injections.

The column experimental system for the TCE degradation studies was designed to minimize mass losses to volatilization and diffusion, because TCE and degradation products had moderate to high vapor pressures. The column influent, consisting of groundwater containing TCE, DCE, and PCE, was contained in a 5-L metalized bag. Influent monitoring over experiments ranging from $200 \mathrm{~h}$ to $1400 \mathrm{~h}$ showed $<3 \%$ mass loss of this influent. Effluent was collected in $154 \mathrm{~mL}$ anaerobic vials with 10 -mm-thick septa tops. The flow rate, was measured from the sample volume and elapsed time. An automated switching valve was used to collect the samples over $24 \mathrm{~h}$ or $48 \mathrm{~h}$ intervals over the $500 \mathrm{~h}$ experiment. Materials used in the column system were stainless steel or PEEK, both of which have extremely low permeabilities to organic compounds. Dissolved oxygen was monitored during this experiment with in-line electrodes, as described earlier. Organic compounds were measured in the inlet and effluent samples by GC-MS.

\subsection{Experimental Data Quality Control}

To ensure the accuracy of the data collected in these bench-scale studies, a percentage of the experiments and sample analysis within experiments were duplicated. In some cases, different types of experiments were used to ultimately determine the same parameter (reducible iron, for example) to ensure the validity of the information obtained.

Batch time-course reduction studies were generally conducted with duplication of dithionite analysis for $10 \%$ to $15 \%$ of the samples. In addition, measurement points close in time show accuracy of the dithionite analysis. Three model parameters were determined from batch reduction studies: reduction rate, disproportionation rate, and reducible iron. The reducible iron (same value for all experiments as the same sediment was used) was determined from simulation fit to five data sets. The mass of reducible iron was fixed for all other experiments in which reduction and disproportionation rates were determined by simulation fit to one or more data sets.

Column reduction studies were conducted with $20 \%$ duplication. Parameters determined from reduction studies included the reducible iron and the reduction rate. Dithionite measurements were made with an automated system at a rate of one per hour, and the point-to-point reproducibility provides an indicator of sample precision. Sediment oxidation studies in columns were conducted with $10 \%$ duplication, where the reducible iron was determined from oxygen breakthrough. Because dissolved oxygen breakthrough analysis requires fewer assumptions, it was considered a more accurate method to determine reducible iron than analysis of reduction column experiments.

Sediment oxidation studies conducted in column experiments relied upon accurate dissolved oxygen measurements, which were used to calculate the mass of reduced iron (duplicate measurement of reduction studies). Two in-line dissolved oxygen electrodes connected to separate meters were used with automated 2-point calibration (at $4 \mathrm{~h}$ to $8 \mathrm{~h}$ intervals) to ensure dissolved oxygen accuracy. Previous experimental studies with these in-line electrodes showed that manual calibrations (likely at a different and variable flow rate) are not considered as accurate as using the automated fluid control system, which injected calibration solutions at the same flow rate as the column effluent. So, to ensure accurate dissolved oxygen measurements over the course of several weeks, an automated system to collect effluent measurements and recalibrate every $4 \mathrm{~h}$ to $8 \mathrm{~h}$ was used. The calibration from other in-line electrodes ( $\mathrm{pH}$, electrical conductivity, Eh) was also achieved with the same fluid system. The two calibration solutions consisted of: 1) oxygen-free water (with continuous He 
bubbling through the solution) with an electrical conductivity of $200 \mu \mathrm{S}$ and a $\mathrm{pH}$ of 8.3 , and 2) oxygen-saturated water (initial air bubbling, left open to the atmosphere) with an electrical conductivity of $420 \mu \mathrm{S}$ and a $\mathrm{pH}$ of 9.4 .

Additional analysis was conducted on sediment and water samples to establish additional information about the redox geochemistry of the Ft. Lewis sediments. Four different types of iron extractions were conducted with duplicate samples for $10 \%$ of the samples. For one type of extraction, duplicate analysis was also conducted for all samples. Liquid effluent samples from column reduction and oxidation studies were analyzed for trace metals by Inductively Coupled Plasma Mass Spectrometry (ICP-MS). For $10 \%$ of these samples, duplicate analysis and duplicate with a spike of all metals was conducted (duplicate shown in Tables 3 and 4).

Batch and column TCE degradation studies were conducted with duplicate GC or GC-MS analysis of $10 \%$ to $15 \%$ of the samples. TCE and degradation products were used to determine the TCE degradation rate and relationship between barrier longevity and TCE degradation rate. Because TCE also undergoes adsorption, positive confirmation of TCE dechlorination was not determined from TCE mass loss, but acetylene production (the main degradation product observed). Therefore, quality control of samples used for acetylene analysis were the most important component to assess degradation. For each sample collected from an experiment, duplicate acetylene analysis was conducted on $50 \%$ or more of the samples. The concentration of TCE and 1,2-trans-DCE was measured from the liquid effluent, and accuracy was established with an internal standard that had similar volatility. The concentration of the lighter organic compounds such as acetylene was measured in the gas phase in the headspace effluent vials with separate gas standards used to establish calibration. 


\section{.}




\subsection{Results - Iron Reduction}

Batch and column reduction studies were used to develop an understanding of how: 1) iron oxide phases in sediment are reduced by the sodium dithionite/potassium carbonate solution, 2) TCE is dechlorinated by ferrous iron phases, and 3) the reduced sediment reactivity evolves over time as the barrier is slowly oxidized by dissolved oxygen. Batch experimental data and simulations were used to quantify the reduction mechanism (Section 4.1) and reaction rates at different temperatures (Section 4.2). Column experiments were used to assess the spatial variability of iron reduction in different sediment samples in a small-flow system at constant $\mathrm{pH}$ (Section 4.3), and in $\mathrm{pH}$ varying conditions (Section 4.4). Changes in iron surface chemistry and mobility of other metals during reduction and oxidation were quantified with liquid and solid extraction analysis of metals (Section 4.5). Results of TCE dechlorination studies are discussed in Section 5.

\subsection{Sediment Reduction in Batch Systems}

The rate of iron reduction and quantity of reduced iron was determined in batch experiments mainly from observations of the rate of disappearance of dithionite. Because dithionite is used for iron reduction (a reaction with a $\sim 5 \mathrm{~h}$ half-life) and disproportionation (reaction 4 , half-life $27 \mathrm{~h}$ ), specific proportions of dithionite/iron are needed, and observations of dithionite use at specific time intervals are used. Given that iron reduction is approximately $5 \mathrm{x}$ faster than disproportionation, dithionite is used entirely for iron reduction at short times $(<5 \mathrm{~h})$, but with greater contact time, dithionite is destroyed proportionally more from disproportionation. To reduce all the iron in the system, dithionite must be added in excess of the reducible iron because of disproportionation use. Sediment reduction experiments can be qualitatively observed from the visual change in sediment color from tan to gray $(<0.1 \mathrm{M}$ dithionite) to black (using $>0.1 \mathrm{M}$ dithionite). As described in Section 5.5, amorphous and some crystalline $\mathrm{Fe}^{\mathrm{III}}$ oxide phases that are dissolved and reduced during reduction produce mainly adsorbed $\mathrm{Fe}^{\mathrm{II}}$ with minor amounts of siderite $\left(\mathrm{Fe}^{\mathrm{II}} \mathrm{CO}_{3}\right)$. At high dithionitel $\mathrm{pH}$ buffer concentrations in contact with sediment for long periods of time, FeS (black precipitate observed) forms presumably because the high ionic strength prevents $\mathrm{Fe}^{\mathrm{II}}$ adsorption and provides a source of S-.

A typical experiment at high dithionite concentration (Figure 2a, data points) shows dithionite use for iron reduction with a shallow slope for the first $100 \mathrm{~h}$ (iron reduction and some disproportionation), then a much steeper dithionite use slope at $>100 \mathrm{~h}$ from disproportionation. In contrast, an experiment using low dithionite concentration relative to reducible iron (Figure $2 b$ ) shows a single slope of dithionite use, and is not useful to determine the disproportionation rate or the total mass of reducible iron, but can be used to determine the iron reduction rate. During reduction, the sediment visually changes color from tan to gray to black with increasing amount of reduction, so visual inspection shows reduction occurring within hours.

Simulation of the third-order reduction (Equation 1) and first-order disproportionation (Equation 4) over time were used to quantify reducible iron mass and disproportionation/iron reduction rates. Simulation of the experiment at high dithionite concentration (Figure 2a, lines) matches the two slopes of the data. A simulation was additionally made with the disproportionation reaction turned off, which shows the fraction of dithionite used for iron reduction only. Simulations of the low dithionite concentration experiment (Figure 2b) with and without disproportionation are nearly the same because the dithionite is all used up at short times for reduction. The experiment at 

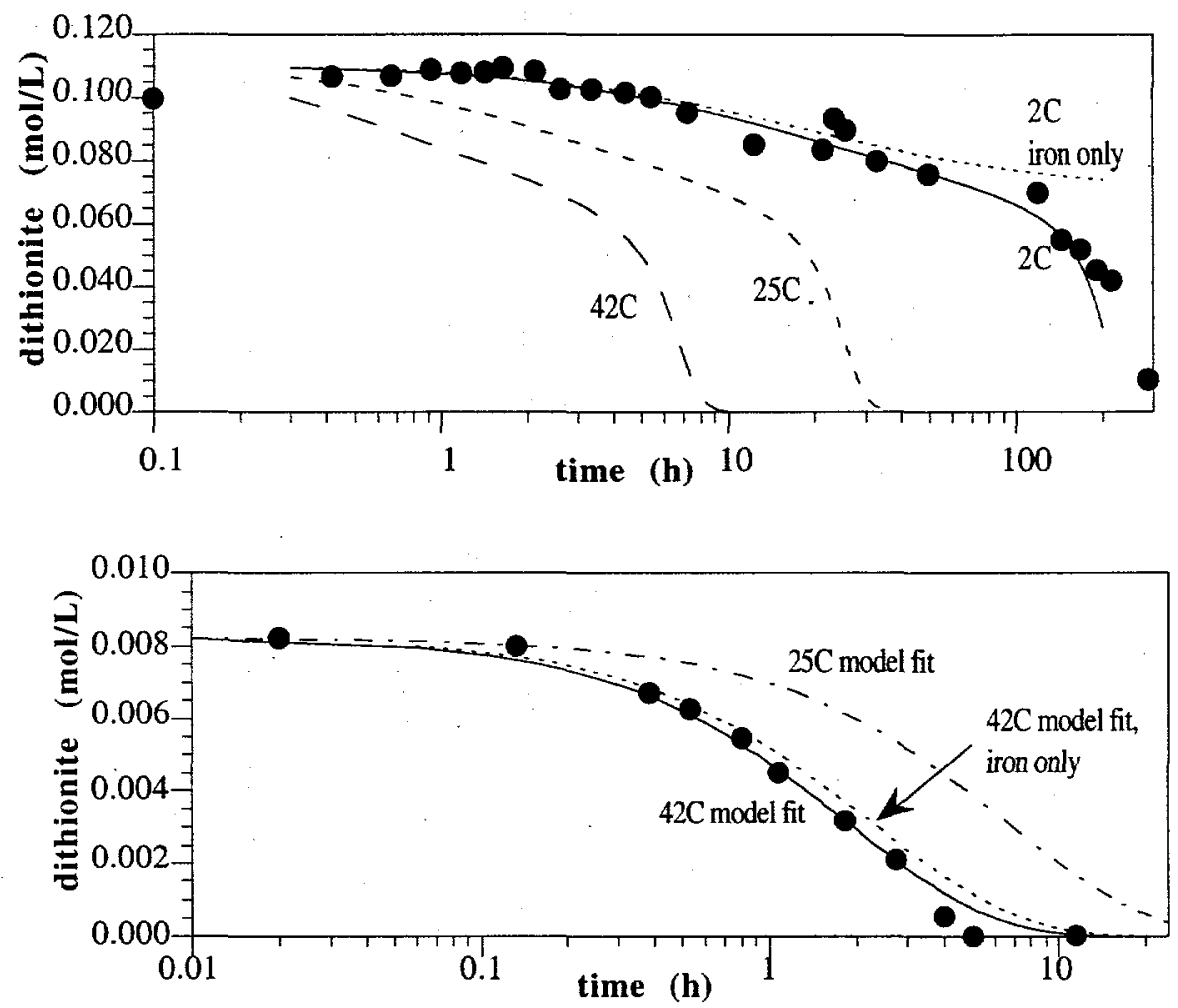

Figure 2. Batch experiment of Ft. Lewis sediment reduction by dithionite at different concentrations. Dithionite use at short time $(<100 \mathrm{~h})$ is mainly due to iron reduction and at $>100 \mathrm{~h}$ is mainly due to disproportionation. Experiments conducted starting with $0.11 \mathrm{~mol} / \mathrm{L}$ sodium dithionite a) and $0.008 \mathrm{~mol} / \mathrm{L}$ sodium dithionite b).

low concentration can be visually shown by data and simulations of the first $50 \mathrm{~h}$ of the high concentration experiment (Figure 2a). There is little use of dithionite for disproportionation in this time range. The mass of iron in all these batch reduction experiments was determined from a series of experiments varying the relative dithionite/iron proportions (Appendix A, experiment KF32) and simulation fit to these five experiments with a single mass of reducible iron. These experiments were also useful to indicate that iron reduction is somewhat more dynamic than can be described with a single reduction reaction. One experiment with very low dithionite concentration reduced only $10 \%$ of the reducible iron and that reduction rate was much faster than when all the iron was reduced. This observed range of reduction rate may be caused by a range of $\mathrm{Fe}^{\mathrm{III}}$ phases: amorphous iron oxides being more easily reduced and crystalline iron oxides being reduced more slowly.

An understanding of the dynamics of iron reduction and disproportionation is useful to upscale the process to the field scale. The iron reduction reaction (rxn 1) is a third-order reaction theoretically (solid line, Figure 3a), but a first-order reaction (rxn 3) can approximate dithionite use in some cases (i.e., over the first half of the reduced iron, dashed line in Figure 3a). 

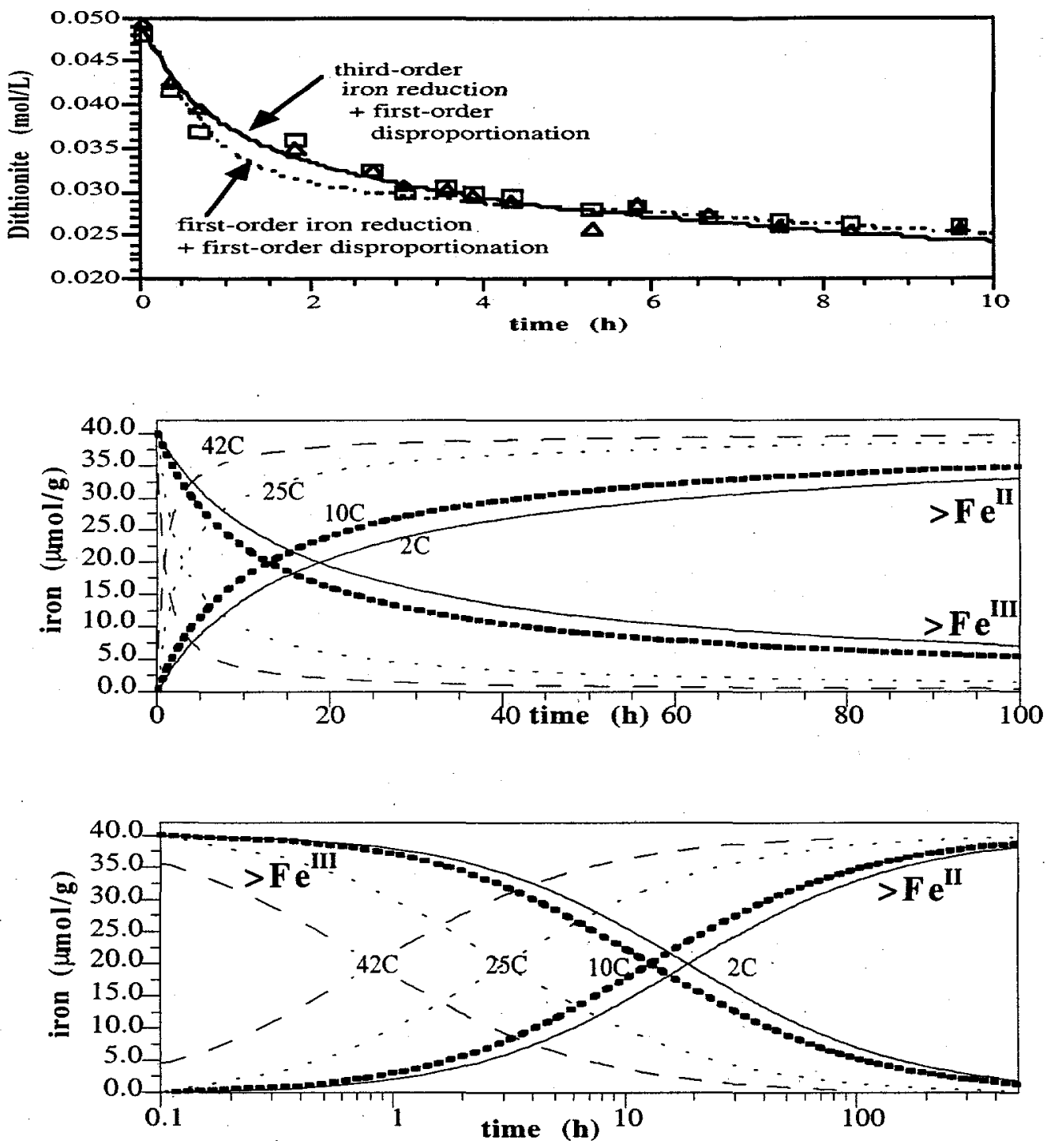

Figure 3. Simulation of iron reduction with: a) third versus first-order iron reduction fit to data, b) simulated iron reduction fraction at different temperatures with linear time, and c) log time.

Although the short time scale $(<2 \mathrm{~h})$ can be fit with a first-order reduction reaction, the model overall underpredicts dithionite use (and overpredicts the amount of reduction) over long periods of time. This data set (Hanford $100 \mathrm{D}$ area sediment) was initially fit with third-order reduction $(4.5 \mathrm{~h}$ half-life) and disproportionation ( $27 \mathrm{~h}$ half-life) reactions. The data were then fit with first-order reduction ( $2 \mathrm{~h}$ half-life, dashed line) without allowing the disproportionation rate to change. This can be incorrectly compensated for by increasing the disproportionation reaction rate to an 18 -h halflife. The result is an artificially low mass of reducible iron, as the actual third-order iron reduction dynamics continue to reduce iron even in tens of hours Figure 2a). Based on simulations of experiments at different temperature (described below), the fraction of reduced iron is predicted in experiments (Figures $3 b$ and $3 c$ ). These simulations show that at $25^{\circ} \mathrm{C}$, the iron reduction half-life is $3.1 \mathrm{~h}$, but $10 \%$ of the iron is still not reduced after $50 \mathrm{~h}$. The implication is that enough reaction time is needed in the field to allow for the dithionite to reduce sediment. 


\subsection{Temperature Effects on Iron Reduction}

Batch iron reduction experiments were conducted at temperatures from $2^{\circ} \mathrm{C}$ to $42^{\circ} \mathrm{C}$ to be able to predict iron reduction and disproportionation rates in different aquifer conditions. Simulation of reactions made to 10 data sets (Appendix A) show that iron reduction (Figure 4a) and disproportionation (Figure $4 \mathrm{~b}$ ) rates changed in a predictable relationship with temperature. Iron reduction averaged $2.27 \mathrm{x}$ decrease with a $10^{\circ} \mathrm{C}$ decrease, or reduction is $4.37 \mathrm{x}$ slower at $10^{\circ} \mathrm{C}$ than at $25^{\circ} \mathrm{C}$. The change in the disproportionation rate over temperature was $3.04 \mathrm{x}$ decrease in rate for each $10^{\circ} \mathrm{C}$ decrease $\left(7.00 \mathrm{x}\right.$ slower at $10^{\circ} \mathrm{C}$ versus $\left.25^{\circ} \mathrm{C}\right)$. The third-order reduction rates and first-order disproportionation rate parameters shown (Figure $4 \mathrm{a}$ and $4 \mathrm{~b}$ ) were used to simulate iron reduction and disproportionation at different temperatures (Figure $3 \mathrm{~b}$ and $3 \mathrm{c}$ ).
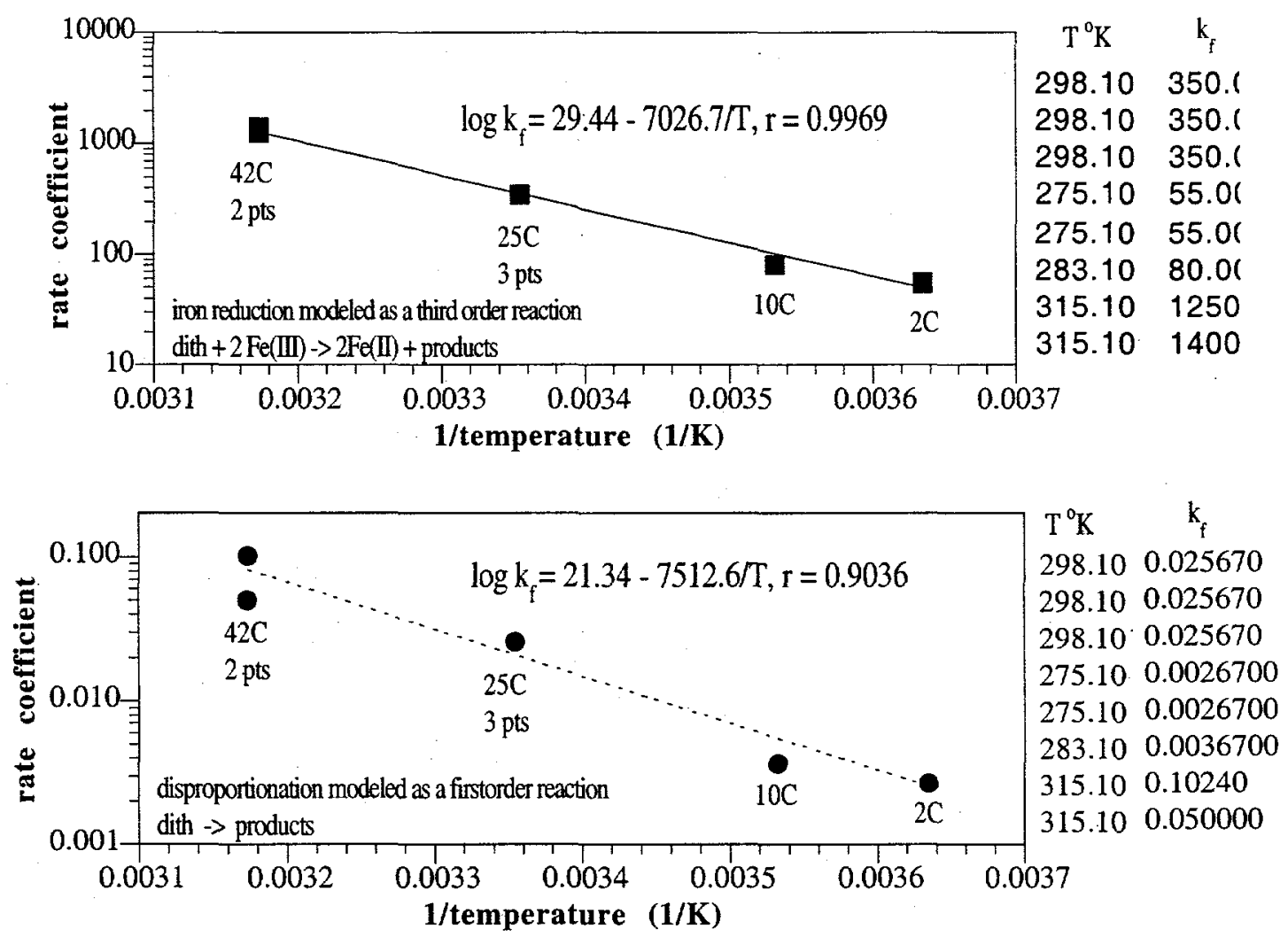

Figure 4. Change in a) iron reduction, and b) disproportionation over temperature from $2^{\circ} \mathrm{C}$ to $42^{\circ} \mathrm{C}$

Contact time between dithionite and sediment needed at different temperatures is needed to balance against other field-scale problems such as dense plume settling. For the purpose of the fieldscale injections, to achieve $80 \%$ reduction of iron, $20 \mathrm{~h}$ of contact time is needed at $25^{\circ} \mathrm{C}$, but $100 \mathrm{~h}$ is needed at $12^{\circ} \mathrm{C}$ (ambient aquifer temperature). Because $100 \mathrm{~h}$ of reaction time is difficult to achieve due to fast advective flow and dense plume sinking (of a high dithionite concentration), it is recommended that injections at Ft. Lewis be heated $\left(18^{\circ} \mathrm{C}\right.$ to $\left.21^{\circ} \mathrm{C}\right)$.

In addition to the reaction time, the proportions of dithionite needed for iron reduction and disproportionation at specific temperatures and contact times are needed at the field scale due to the cost of chemicals. Over time, a greater fraction of dithionite is used for disproportionation, as previously shown (Figure 2a). The additional amount of dithionite needed for disproportionation 
was calculated (Table 5) at $10^{\circ} \mathrm{C}$ and $25^{\circ} \mathrm{C}$, based on reaction rates in experiments (Table 1 , Appendix A, Figure $4 \mathrm{a}$ and $4 \mathrm{~b}$ ). A value greater than 1.0 for the multiplier for disproportionation is the additional fraction of dithionite mass needed for disproportionation. These values range from 1.10 when $50 \%$ of the iron is reduced to over 4.00 to reduce $99+\%$ of the iron. The competition between iron reduction and disproportionation for dithionite mass can be clearly seen on a log time plot (Figure 2a), which clearly shows that the first $80 \%$ of the iron can be efficiently reduced with little dithionite lost to disproportionation (multiplier is 1.3 , regardless of temperature). It is increasingly less efficient to reduce $>80 \%$ of the iron, due to the large dithionite use for disproportionation.

Table 5. Fraction of dithionite use for iron reduction and disproportionation at $10^{\circ} \mathrm{C}$ and $25^{\circ} \mathrm{C}$

\begin{tabular}{|c|c|c|c|c|c|}
\hline $\begin{array}{c}\text { contact time } \\
\text { (h) }\end{array}$ & $\begin{array}{c}10^{\circ} \mathrm{C}- \\
\text { fraction iron } \\
\text { reduced }\end{array}$ & $\begin{array}{c}\text { multiplier for } \\
\text { disprop.* }\end{array}$ & $\begin{array}{l}\text { contact time } \\
\text { (h) }\end{array}$ & $\begin{array}{l}25^{\circ} \mathrm{C} \\
\text { fraction iron } \\
\text { reduced }\end{array}$ & $\begin{array}{c}\text { multiplier for } \\
\text { disprop.* }\end{array}$ \\
\hline 20 & 0.43 & 1.10 & 7 & 0.516 & 1.09 \\
\hline 30 & 0.55 & 1.19 & 10 & 0.656 & 1.12 \\
\hline 50 & 0.67 & 1.20 & 15 & 0.749 & 1.19 \\
\hline 75 & 0.80 & 1.24 & 20 & 0.879 & 1.21 \\
\hline 100 & 0.86 & 1.33 & 25 & 0.908 & 1.26 \\
\hline 150 & 0.937 & 1.60 & 30 & 0.937 & 1.37 \\
\hline 200 & 0.966 & 2.30 & 35 & 0.948 & 1.56 \\
\hline 250 & 0.989 & 2.90 & 40 & 0.966 & 1.94 \\
\hline 300 & 0.992 & 4.30 & 50 & 0.995 & 2.42 \\
\hline
\end{tabular}

* multiplier $=$ dithionite used to reduce iron plus disproportionation, where 1.00 is defined at each contact time for iron reduction only. Assumes dithionite is in excess of the reducible iron.

\subsection{Sediment Reduction and Oxidation in Columns}

Column experiments in which Ft. Lewis sediment is reduced with the dithionite/pH buffer solution then oxidized with oxygen-saturated water were conducted to determine reducible iron mass and reduction/oxidation rates. Reduction information determined in columns is more applicable to the field scale than to results of batch experiments. Reaction rates in column and field systems are typically slower than rates observed in batch systems, due to some particle breakup in batch systems (i.e., artifacts), and some slow physical access to sites in columns that does not occur in batch. Although column experiments incorporate some aspects of the field scale such as the advective flow of mobile solutes through the reactive immobile surfaces, these small systems are not representative of all aspects of the field scale, as discussed in this section.

Calculation of the reducible iron from column reduction experiments involves mass balance calculations of both iron reduction and disproportionation reactions. The differing time scales of the reactions can be observed from dithionite breakthrough (Figure 5a and 5b). By injecting dithionite. at a flow rate such that the residence time $(4 \mathrm{~h}$, Figure $5 \mathrm{a})$ of dithionite is similar to the reduction rate half-life $(5 \mathrm{~h})$ results in approximately half of the dithionite consumed in the reduction of iron (Figure 5a). If the iron mass is large relative to the dithionite concentration, the dithionite concentration in the effluent would remain constant. However, with the limited number of reducible iron oxides in natural sediments used, the dithionite concentration increases over time as less iron is reduced (Figure 5a). At a slower flow rate (i.e., longer residence time, Figure 5b), more dithionite is consumed. However, disproportionation (half-life $27 \mathrm{~h}$ ) consumes enough mass in this 5-day experiment to result in decreasing long-term dithionite concentration. 

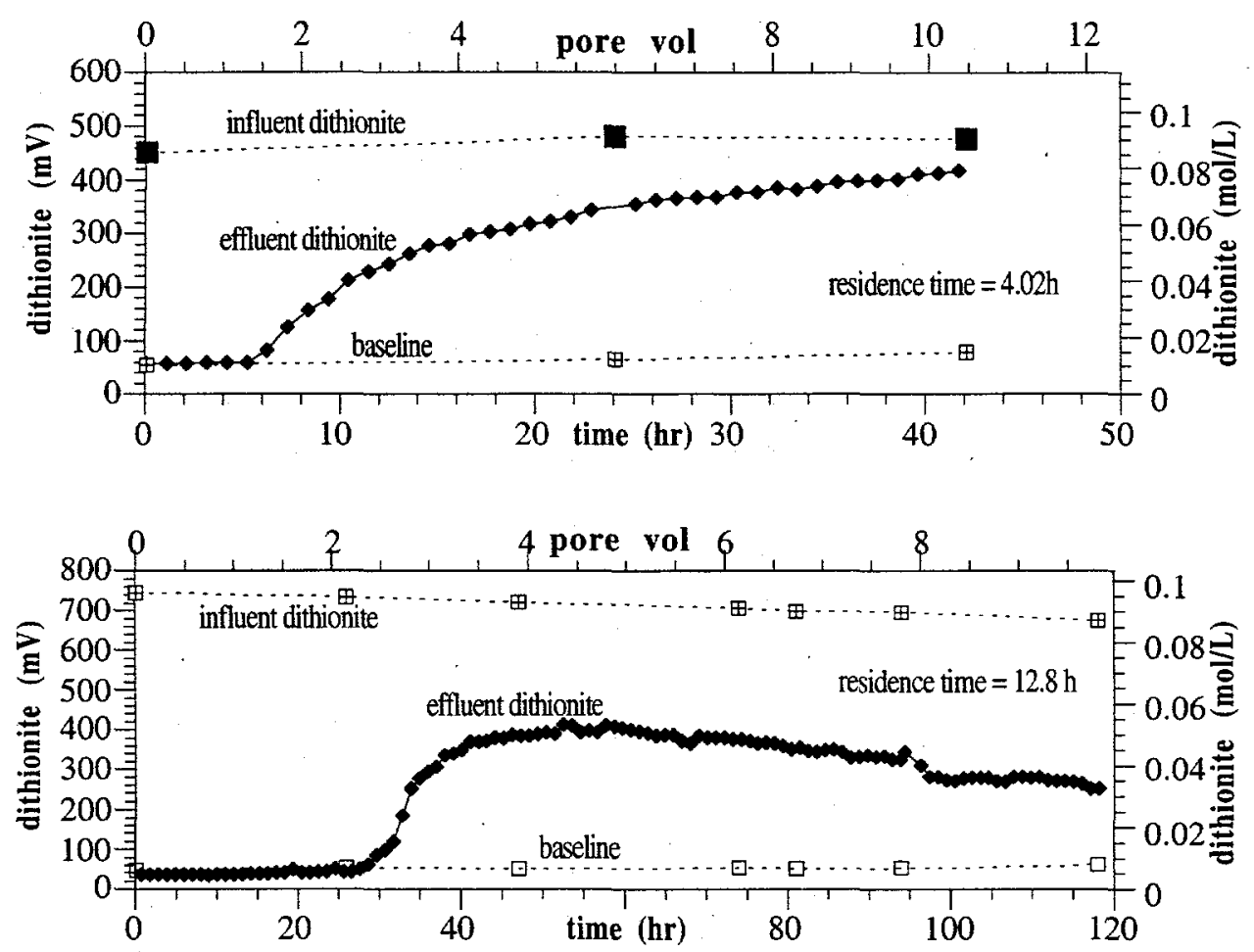

Figure 5. Dithionite influent and effluent in a reactive sediment column with a sediment-dithionite contact time of: a) $4.0 \mathrm{~h}$, and b) $12.8 \mathrm{~h}$.

Reduction experiments (27) showed that the sediments from the Ft. Lewis reduction field site averaged $62.8 \pm 39.7 \mu \mathrm{mol} / \mathrm{g}(0.351 \pm 0.222 \%)$ of reducible iron (Table 2$)$. This $63 \%$ standard deviation is large, and indicates locations within the aquifer with very little iron and other areas with $\sim 2 \mathrm{x}$ the average amount of reducible iron. Well RM-9 averaged $49.1 \pm 3.25 \mu \mathrm{mol} / \mathrm{g}(0.274 \%)$ of reducible iron ( 3 experiments). Column experiments were also conducted with sediment samples from six U.S. Geological Survey wells. All 14 reduction experiments averaged $45.6 \pm 33.3 \mu \mathrm{mol} / \mathrm{g}$ $(0.255 \pm 0.186 \%)$ of reducible iron (Appendix B), meaning that the location where the reduction experiment is taking place averages $30 \%$ greater iron than the field experimental site.

The rate of iron reduction in columns can be calculated from dithionite breakthrough curves and was compared with batch iron reduction. The rate of iron reduction is calculated using the steadystate concentration of dithionite in the effluent before the system is site limited, meaning the dithionite concentration at the time between steep and shallow dithionite breakthrough. At a residence time of $4.0 \mathrm{~h}$, this occurred at $10 \mathrm{~h}$ (Figure $5 \mathrm{a}$ ), and with a $12.8 \mathrm{~h}$ residence time, this occurred at $36 \mathrm{~h}$ (Figure $5 \mathrm{~b}$ ). The column reduction experiments averaged $6.82 \pm 2.46 \mathrm{~h}$ for the reduction half-life, as opposed to $3.1 \mathrm{~h}$ for six batch experiments $\left(25^{\circ} \mathrm{C}\right)$. Reduction in columns is likely slightly slower due to physical access limitations to sites, which does not occur in batch systems.

Reduced sediment columns are then oxidized with oxygen-saturated water to provide an additional measure of the amount of reduced iron as well as a measure of the oxidation rate of the reduced iron. The reducible iron mass from these oxidation experiments is considered the most accurate at reflecting the mass of reduced iron because only iron oxidation reactions (rxn 10 and 11) are occurring. Oxidation column experiments were also used to test the prediction of reduced barrier longevity and quantify sediment oxidation rates. A total of 11 oxidation experiments were conducted on reduced Ft. Lewis sediment that ranged in time from $70 \mathrm{~h}$ to $500 \mathrm{~h}$. In some cases, the 
experiments were conducted long enough to completely oxidize the sediment, while other experiments were stopped before the sediment was completely oxidized. In all cases, the oxygen breakthrough curves were used to calculate the mass of reduced iron in the column that consumed the oxygen. These values were compared with the mass of reduced iron calculated from dithionite breakthrough curves indicated that $50 \%$ to $100 \%$ of the iron was oxidized in the experiments.

The size and shape of the oxygen breakthrough data from columns is used to calculate the mass of reduced iron and provide oxidation rate information (all experiments in Appendix C). In one experiment (Figure 6a), although oxygen saturated water is being injected into the column, the effluent is oxygen free for the first 260 pore volumes due to oxygen consumption by the ferrous iron. In this case, the oxygen breakthrough curve shape is can be modeled with a single type of site being oxidized (i.e:, the shape of the breakthrough curve has a single shape). In contrast, a different experiment run at faster velocity reveals a change in slope (Figure 6b). The rapid rise in
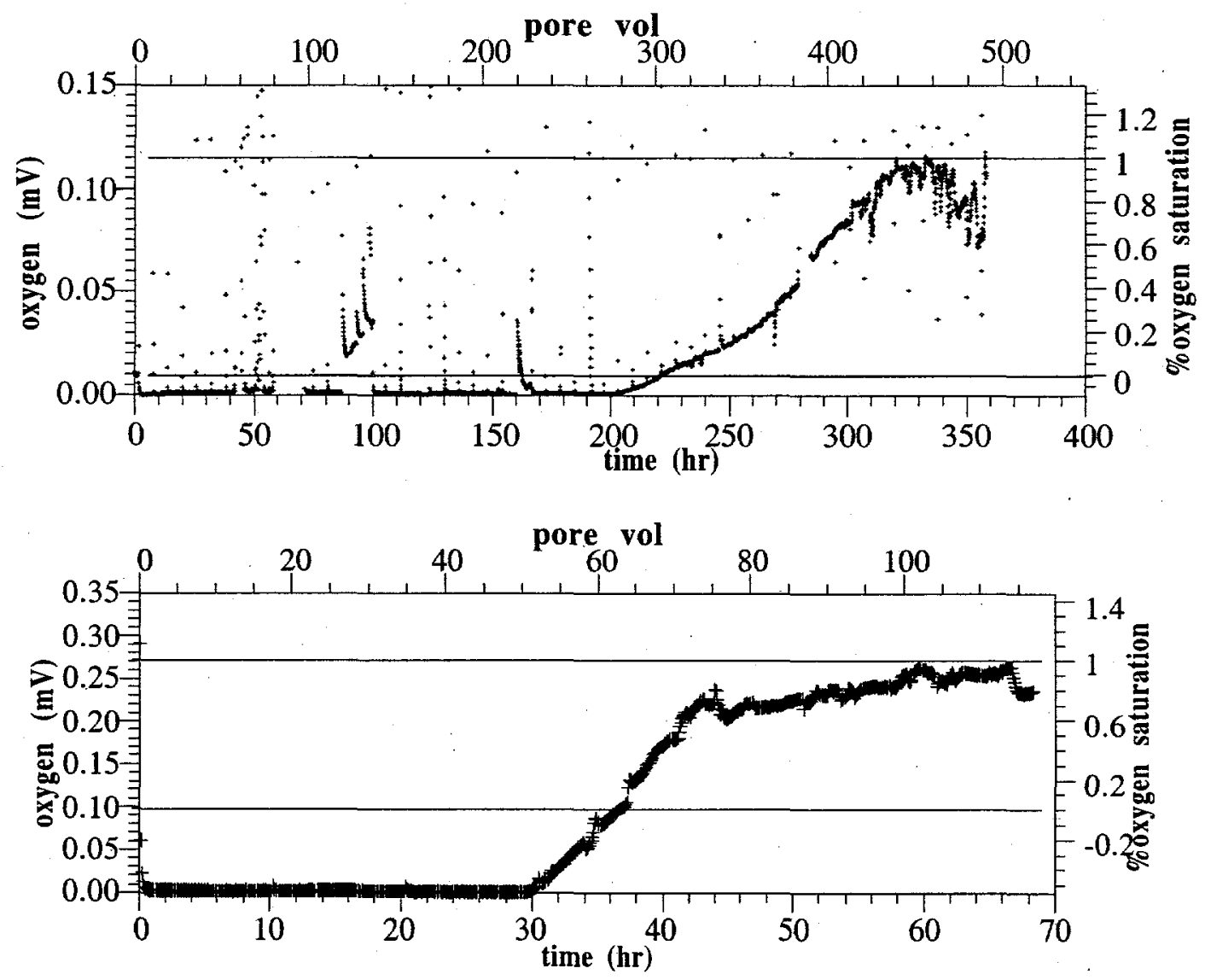

Figure 6. Oxidation of a reduced sediment column with dissolved oxygen in water with residence time of: a) $0.72 \mathrm{~h}$ in a highly reduced sediment column, and b) $0.58 \mathrm{~h}$ in a partially reduced sediment column. 
oxygen levels through $3 / 4$ of saturation, then a fairly slow increase to saturated levels indicate a fraction of sites that are slow to oxidize in the relatively short time scale of this experiment (i.e., $70 \mathrm{~h}$ ). The oxidation of reduced iron in the natural sediment appears to be more complex than a single oxidation reaction, and is likely controlled by both chemical and physical processes, as shown by results of a different redox study in the Hanford 100D sediments. Physical rate limitations were shown by breakthrough curve tailing of dissolved oxygen in nonreduced sediment, indicating diffusional limitations accessing a fraction of the pore volume. Oxygen breakthrough data at shorter residence times in that study showed multiple slope changes, indicating quickly and slowly oxidizing sites. It is hypothesized that the fast oxidizing sites represent adsorbed ferrous iron, and the slowly oxidizing sites represent siderite, as discussed in the next section for the Ft. Lewis sediments.

The applicability of batch and column studies to the field scale depends upon accounting for large-scale chemical and physical variability. Although column experiments incorporate some aspects of the field scale such as the advective flow of mobile solutes through the reactive immobile surfaces, these small systems are not representative of all aspects of the field scale. Groundwater systems contain: a) natural physical and chemical heterogeneities, b) unique flow fields, c) different temperature, and d) a wide range of porous media size that are not represented in column experiments. Because of the small $(1 \mathrm{~cm}$ diameter $\times 10 \mathrm{~cm}$ length; up to $10 \mathrm{~cm}$ diameter $\mathrm{x} 50 \mathrm{~cm}$ length) size of columns, natural sediment from cores is sieved and repacked, so does not incorporate natural heterogeneity patterns (but rather point samples). The chemical spatial variability of the sediment was addressed in this study by statistical variability in experiments with sediments from different boreholes. Because of the small size of column systems, natural sediment was sieved, and the $<2 \mathrm{~mm}$ or $<4 \mathrm{~mm}$ fraction was used in experiments. It was assumed that the surface area of larger particles was minimal and nonreactive, which may slightly underestimate the fraction of reducible iron in the sediment. Intermediate-scale experiments currently in progress use $<2.5 \mathrm{~cm}$ fraction, so will be much closer to field sediment. Because some cobbles in the gravel units are $>10 \mathrm{~cm}$, a fully representative experiment would have to include sediment from a large borehole $(>10 \mathrm{~cm}$ diameter), which is not cost effective. Some column experiments were conducted at groundwater temperatures $\left(11^{\circ} \mathrm{C}\right)$, but most were conducted at $25^{\circ} \mathrm{C}$. Differences in reduction over temperature were discussed previously in Section 4.2.

\subsection{Sediment Reduction and pH Change}

To determine the concentration of $\mathrm{pH}$ buffer needed to efficiently reduce sediment without resulting in significant iron mobility, the $\mathrm{pH}$ and effluent iron was measured during reduction in columns. The relationship between the $\mathrm{pH}$ buffer concentration used during dithionite treatment and the resulting reactivity of sediment was examined in a series of column experiments in which the potassium carbonate concentration was varied $(4 \mathrm{x}, 3 \mathrm{x}, 2 \mathrm{x}, 1 \mathrm{x}, 0.5 \mathrm{x})$ relative to the dithionite concentration. During reduction in columns, the $\mathrm{pH}$ and aqueous iron concentration were measured in the effluent water. The influent $\mathrm{pH}$ (dithionite solution) is 10.5 to 11.0 , and with a high buffer concentration (i.e., $4 \mathrm{x}$ or $3 \mathrm{x}$ times the $0.09 \mathrm{~mol} / \mathrm{L}$ sodium dithionite), the effluent $\mathrm{pH}$ is typically constant at 9.5 to $10.0^{\circ}$ (Figure 7a). At lower $\mathrm{pH}$ buffer concentrations, reduction and disproportionation reactions (reactions $1,2,4$ ) produce $\mathrm{H}^{+}$that is beyond the sediment and solution $\mathrm{pH}$ buffering capacity, so the $\mathrm{pH}$ drops at the reactive front. With Ft. Lewis sediments, with $0.18 \mathrm{~mol} / \mathrm{L}$ $\mathrm{K}_{2} \mathrm{CO}_{3}$ (2x dithionite) the $\mathrm{pH}$ dipped to 8.8, with $0.09 \mathrm{~mol} / \mathrm{L} \mathrm{K}_{2} \mathrm{CO}_{3}(1 \mathrm{x})$ the $\mathrm{pH}$ dipped to 7.7 , and at $0.045 \mathrm{~mol} / \mathrm{L} \mathrm{K}_{2} \mathrm{CO}_{3}(0.5 \mathrm{x})$ the $\mathrm{pH}$ dipped and stayed at 2.3. In a previous study with Hanford 100D sediments, $4 \mathrm{x}$ and $2 \mathrm{x}$ buffer concentrations showed no $\mathrm{pH}$ change, but the $1 \mathrm{x}$ buffer experiment showed a $\mathrm{pH}$ drop to 3.3. By itself, the $\mathrm{pH}$ data indicates little effect of changing buffer concentration except at very low $(0.5 \mathrm{x})$ buffer concentration. However, the effect on the mobility of iron and the amount of iron reduced was significant. 

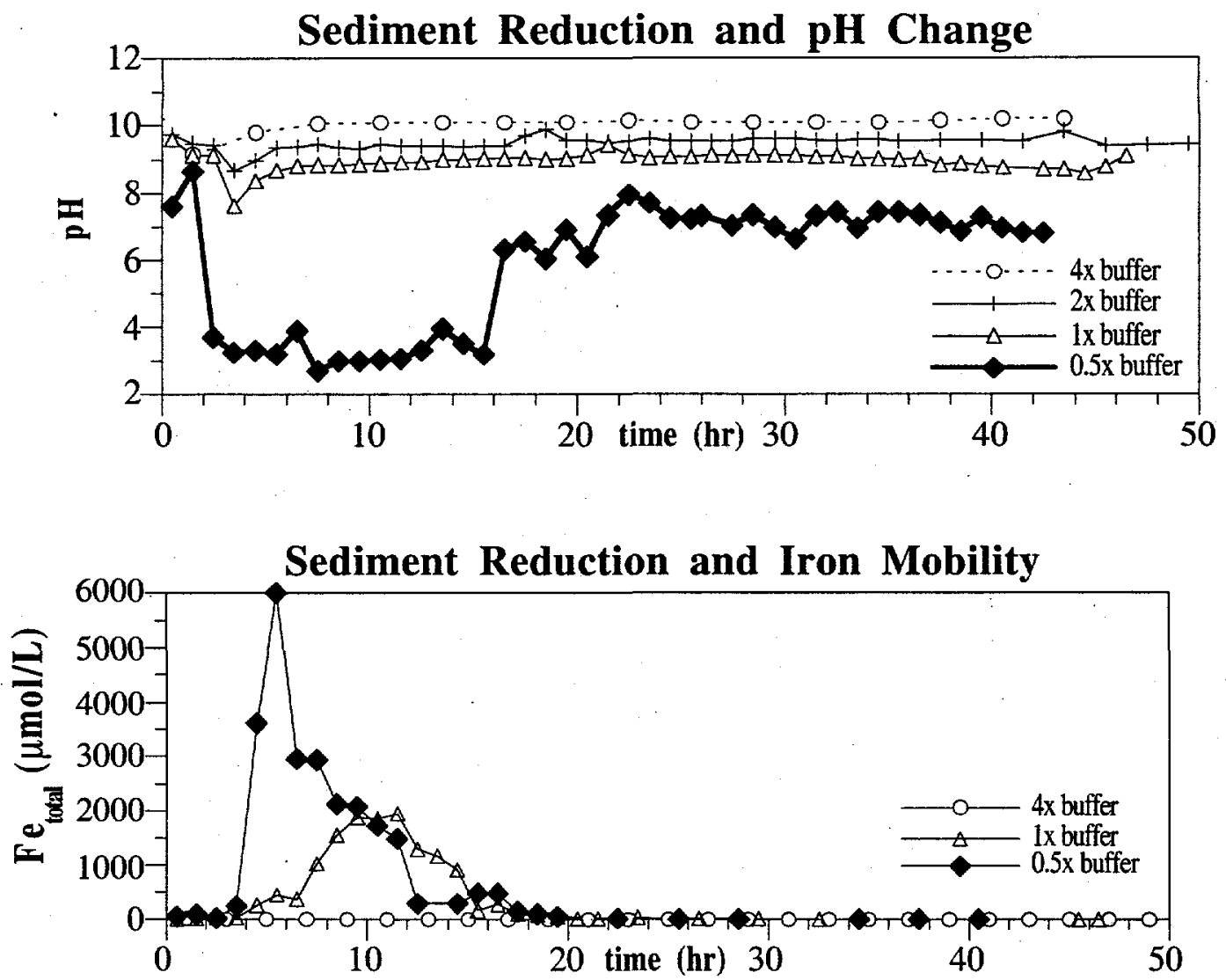

Figure 7. Sediment reduction column experiments at different potassium carbonate concentrations relative to sodium dithionite concentration with the resulting $\mathrm{pH}$ and the total aqueous iron concentration measured in effluent samples.

Iron mobility out of the column was a direct function of how low and how long the $\mathrm{pH}$ of the sediment remained acidic (Figure $7 \mathrm{~b}$ ). With $0.36 \mathrm{~mol} / \mathrm{L} \mathrm{K}_{2} \mathrm{CO}_{3}(4 \mathrm{x}$ dithionite), the total aqueous iron in the effluent $\left(\mathrm{Fe}^{\mathrm{Il}}\right)$ averaged $0.036 \mathrm{mg} / \mathrm{L}$ with the first sample at $1.25 \mathrm{mg} / \mathrm{L}$. The total mass of iron in the effluent was $0.021 \%$ of the iron in the column. This result was consistent with iron extractions of the sediment, showing very little movement of iron in these highly $\mathrm{pH}$ buffered systems where any $\mathrm{Fe}^{\mathrm{II}}$ produced is highly adsorbed to sediment surfaces. However, because $\mathrm{Fe}^{\mathrm{II}}$ is stable in solution at a $\mathrm{pH}$ below 8.0, experiments in which the $\mathrm{pH}$ dropped showed some iron mobility. With $0.09 \mathrm{~mol} / \mathrm{L}$ $\mathrm{K}_{2} \mathrm{CO}_{3}$ (1x dithionite; triangles in Figure $7 \mathrm{~b}$ ), where the $\mathrm{pH}$ dipped briefly to 7.7 (Figure 7a), the aqueous $\mathrm{Fe}^{\mathrm{Il}}$ was $0.94 \%$ of the reducible iron in the column. Finally, with $0.045 \mathrm{~mol} / \mathrm{L} \mathrm{K}_{2} \mathrm{CO}_{3}(0.5 \mathrm{x}$ dithionite; diamonds in Figure $7 \mathrm{~b}$ ), where the $\mathrm{pH}$ remained $<3.0$ for $12 \mathrm{~h}$, the advection and reduction process removed $3.3 \%$ of the reducible iron in the column. There was significant precipitate forming in the tubing of the low $\mathrm{pH}$ experiment, as iron was oversaturated and was oxidizing to insoluble $\mathrm{Fe}^{\mathrm{III}}$ oxides. The use of injecting aqueous $\mathrm{Fe}^{\mathrm{II}}$ species at the field scale at low $\mathrm{pH}$ has been observed ineffective due to iron mobility (Seaman et al. 1999).

The effectiveness of the reduction at different $\mathrm{pH}$ buffers was measured by oxidizing columns (to measure reduced iron) and conducting TCE degradation experiments. In all the reduction experiments, sediment columns were treated with the same concentration of sodium dithionite $(0.09 \mathrm{~mol} / \mathrm{L})$ 
at the same flow rate for $45 \mathrm{~h}$ (i.e., differed only in the buffer concentration). Although the $\mathrm{pH}$ drop was small in most cases, and the mass of iron removed from columns was small, there was a significant difference in the mass of reduced iron in columns. Using the maximum buffer $(4 \mathrm{x}), 85 \%$ of the reducible iron was reduced (i.e., more is reduced with longer contact time), but even with slightly less buffer (3x), only $50 \%$ of the iron was reduced. The resulting TCE degradation half-life indicated even worse performance, with a 200 -h half-life for the $0.09 \mathrm{~mol} / \mathrm{L}$ buffer (1x) and a 1400 -h half-life for the $0.045 \mathrm{~mol} / \mathrm{L}(0.5 \mathrm{x})$ buffer (Appendix D, KF62a and 62b). Comparing results to those of the partial reduction studies, these low degradation rates indicate the $1 \mathrm{x}$ buffer reduction was $<27 \%$ reduced, and the $0.5 \mathrm{x}$ buffer reduction was $\sim 11 \%$ reduced (Table 6 ). The general conclusion is that a high buffer concentration is needed to efficiently reduce iron species for TCE dechlorination.

Table 6. Summary of reduction experiments with different $\mathrm{pH}$ buffer concentration

\begin{tabular}{lccc}
\multicolumn{1}{c}{$\begin{array}{c}\text { buffer concentration } \\
(\mathrm{mol} / \mathrm{L})\end{array}$} & iron reduced $(\mu \mathrm{mol} / \mathrm{g})$ & iron reduced (fraction) & \multicolumn{2}{c}{ TCE degradation half-life } \\
\hline $0.36(4 \mathrm{x}$ dithionite conc.) & 137.0 & 85 & $<16^{* *}$ \\
$0.27(3 \mathrm{x})$ & $79.2,76.3$ & 49,47 & - \\
$0.09(1 \mathrm{x})$ & 58.2 & 37 & 200 \\
$0.045(0.5 \mathrm{x})$ & 41.5 & 26 & 1400 \\
\hline
\end{tabular}

*based on $159 \mu \mathrm{mol} / \mathrm{g}$ as the maximum reducible iron measured for this sediment (Table 2).

**16-h half-life was measured with $53 \%$ reduced sediment, and a 1.2 -h half-life was measured with $100 \%$ reduced sediment (Table 12).

\subsection{Geochemical Changes During Redox}

In addition to monitoring dithionite concentration during reduction and dissolved oxygen concentration during oxidation, other solution and surface constituents were monitored to address specific issues related to the impact of the redox manipulation of sediments: 1) changes in solid phase iron mineralogy, and 2) solution phase metals mobility. Iron extractions were conducted on unreduced, reduced, and reduced/oxidized sediments to specifically determine the changes in iron phases that occur during reduction and subsequent oxidation of the sediment. This information was used to determine if the dithionite treatment would leach significant iron mass from one area to another and if sediment can be effectively re-reduced. To assess the potential migration of heavy metals that could occur as the natural (oxic) sediment is reduced, the mobility of metals was monitored during sediment reduction and oxidation in columns.

Iron extractions conducted on the unaltered Ft. Lewis aquifer sediment (Table 7) had an average of $0.40 \pm 0.29 \%$ iron oxides and carbonates, with a range of $0.05 \%$ to $1.05 \%$ for 22 sediment samples from boreholes. The $\mathrm{Fe}^{\mathrm{III}}$ phases accounted for $58 \%$ to $90 \%$ of the total, with the remainder $\mathrm{Fe}^{I I}$ phases. Measurable $\mathrm{Fe}^{I I I}$ phases included $25 \%$ amorphous and $\sim 60 \%$ crystalline, whereas measurable $\mathrm{Fe}^{\mathrm{II}}$ phases appeared to be siderite $\left(\mathrm{Fe}^{\mathrm{Il}} \mathrm{CO}_{3}\right)$. As a check of the accuracy of the total $\mathrm{Fe}^{\mathrm{III}}$ $+\mathrm{Fe}^{\mathrm{II}}$ extractant method (with ferrozine analysis), the extractant water was analyzed for $\mathrm{Fe}$ and $\mathrm{Mn}$ by ICP-MS (Heron et al. 1994). Results indicated the iron values measured by ferrozine were accurate and that only $3.7 \%$ of the reduced phases were $\mathrm{Mn}$ (i.e., iron phases were by far the dominant redox phases). The extraction for total $\mathrm{Fe}^{\mathrm{II}}$ oxides showed that $50 \%$ to $60 \%$ of the phases were not accounted for in the amorphous and crystalline $\mathrm{Fe}^{\mathrm{III}}$ oxide extractions (Table 8). Unaccounted for phases may include $\mathrm{Fe}^{\mathrm{III}}$ in clay. Samples were submitted for identification of clay phases by $x$-ray diffraction, but the mass of clay was too small for analysis. Phase separations concentrating the clay phases would have to be conducted, followed by Mossbauer spectroscopy to identify iron mass and oxidation states. 
Table 7. Iron analysis of sediment samples

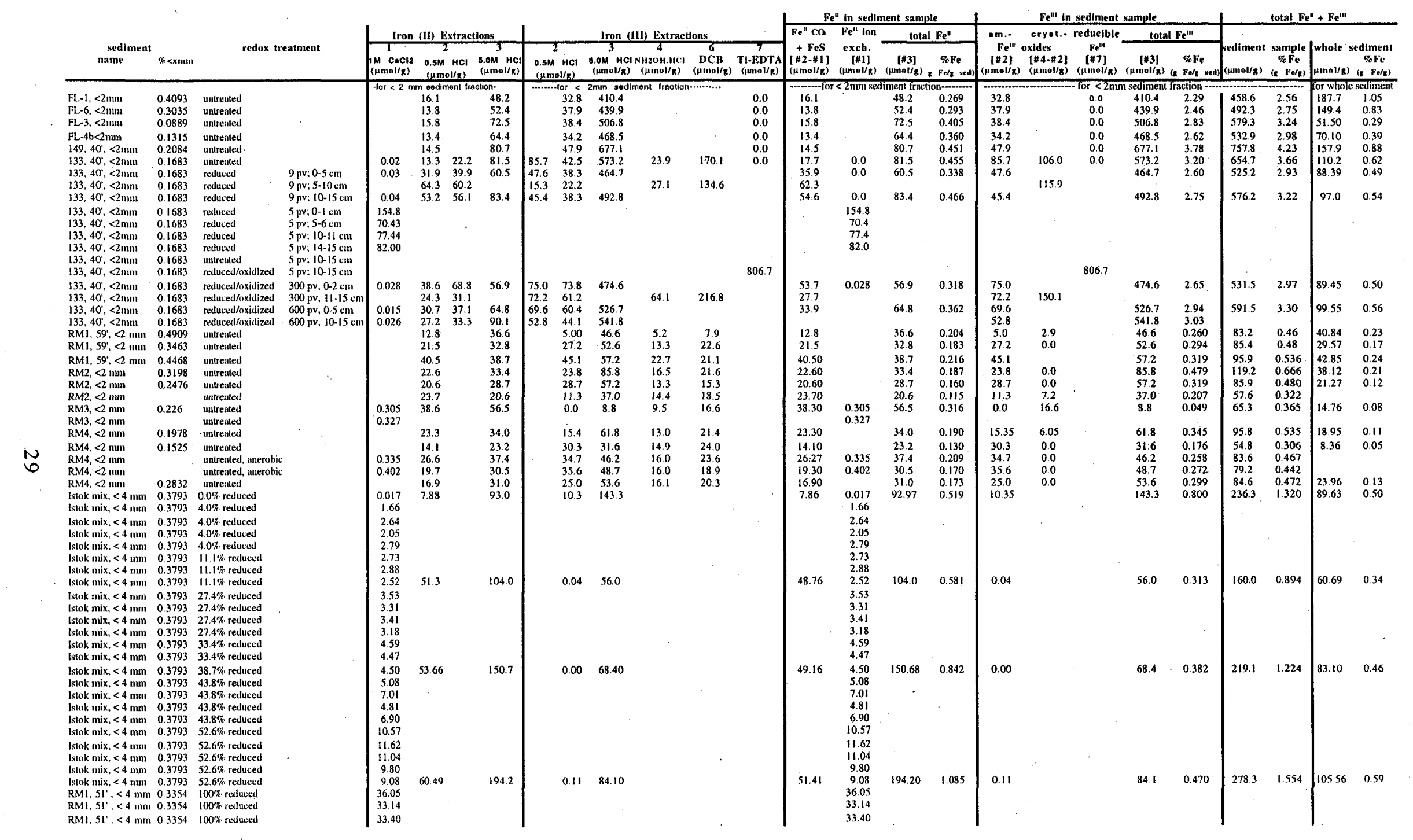


Table 8. Summary of iron oxide phases changes during reduction and oxidation

\begin{tabular}{|c|c|c|c|c|c|c|c|c|}
\hline sediment & $\begin{array}{l}\text { total } \\
\mathrm{Fe}^{\mathrm{II}}\end{array}$ & $\begin{array}{l}\text { total } \\
\mathrm{Fe}^{\mathrm{III}}\end{array}$ & Fe lost & ads. $\mathrm{Fe}^{\mathrm{II}}$ & $\mathrm{Fe}^{\mathrm{II}} \mathrm{CO}_{3}$ & $\begin{array}{l}\text { am- } \\
\mathrm{Fe}^{\mathrm{II}}\end{array}$ & $\begin{array}{l}\text { crystalline } \\
\mathrm{Fe}^{\mathrm{III}}\end{array}$ & $\begin{array}{l}\text { Other } \\
\mathrm{Fe}^{\mathrm{III}}\end{array}$ \\
\hline untreated & $12 \%$ & $\overline{88 \%}$ & $0 \%$ & $0 \%$ & $3 \%$ & $13 \%$ & $16 \%$ & $59 \%$ \\
\hline reduced 9pv & $21 \%$ & $75 \%$ & $3 \%$ & $15 \%$ & $6 \%$ & $7 \%$ & $17 \%$ & $50 \%$ \\
\hline $\begin{array}{l}\text { red./ox } \\
600 \mathrm{pv}\end{array}$ & $9 \%$ & $80 \%$ & $10 \%$ & $6 \%$ & $6 \%$ & $10 \%$ & $23 \%$ & $58 \%$ \\
\hline
\end{tabular}

Detailed iron extractions conducted on a fully reduced sediment showed a decrease in $\mathrm{Fe}^{\mathrm{III}}$ phases $(\sim 15 \%)$ and an increase in $\mathrm{Fe}^{\mathrm{II}}$ phases $(\sim 12 \%)$, although there was considerable variability in the results. One sediment (well 133, $40 \mathrm{ft}$ depth) showed that the dithionite reduction resulted in the amorphous $\mathrm{Fe}^{\mathrm{IIl}}$ oxides decreasing by half $(\sim 40 \mu \mathrm{mol} / \mathrm{g})$, but showed no measurable decrease in the crystalline $\mathrm{Fe}^{\mathrm{III}}$ oxides. The corresponding increase in $\mathrm{Fe}^{\mathrm{II}}$ oxides was greater, with siderite increasing by $30 \mu \mathrm{mol} / \mathrm{g}$ and ion exchangeable (i.e., adsorbed) $\mathrm{Fe}^{\mathrm{II}}$ increasing by $154 \mu \mathrm{mol} / \mathrm{g}$. This was not unexpected, as not all $\mathrm{Fe}^{\mathrm{III}}$ phases are accounted for in extractions. Corresponding reduction from column experiments in which sediments were oxidized indicated $153 \mu \mathrm{mol} / \mathrm{g}$ for this sediment, so it appears that adsorbed $\mathrm{Fe}^{\mathrm{II}}$ was the main $\mathrm{Fe}^{\mathrm{II}}$ phase created by dithionite reduction ( $80 \%$ to $100 \%$ ), with minor amounts of siderite (Table 8).

Iron extractions conducted on sediment that was reduced, then oxidized indicated a general increase in $\mathrm{Fe}^{\mathrm{III}}$ phases $(\sim 5 \%)$ and a decrease in $\mathrm{Fe}^{\mathrm{II}}$ phases $(11 \%$; Table 8$)$. The adsorbed $\mathrm{Fe}^{\mathrm{II}}$ appeared to decrease significantly, although siderite did not decrease or decreased to some extent for some sediments. The decrease in $\mathrm{Fe}^{1 l}$ phases $(11 \%)$ was greater than the corresponding increase in $\mathrm{Fe}^{\text {III }}$ phases $(5 \%)$, although there was considerable variability at these low iron concentrations. Extractions also indicated that there may have been a $3 \%$ loss in total iron during reduction and a $10 \%$ during 600 pore volumes of subsequent oxidation (relative to the iron in untreated sediment. These values for iron mass loss are considerably greater (and suspect) compared to the accurate analysis of iron in aqueous samples during reduction (Section 4.4) in which $0.021 \%$ iron was present in the effluent for most reductions ( $4 \mathrm{x}$ buffer concentration). The iron phase changes reported for $\mathrm{Ft}$. Lewis sediments are similar to that observed for Hanford sediments. Re-reduction experiments have been conducted with Hanford sediments confirmed similar mass of reducible iron when re-reduced, indicating little overall migration of iron and zones can be re-reduced with nearly the same efficiency.

Detailed iron extractions were also conducted on sediments that were partially reduced for comparison to reduced iron measurements by dissolved oxygen column experiments. Results showed that the various iron extractions generally showed a trend of increasing $\mathrm{Fe}^{\mathrm{II}}$ phases and decreasing $\mathrm{Fe}^{\mathrm{III}}$ phases, but these were not as accurate as the column experimental data. Although the total $\mathrm{Fe}^{\mathrm{II}}$ increased linearly with greater reduction, the total $\mathrm{Fe}^{\mathrm{III}}$ did not linearly decrease (Figure 8a), and the total $\mathrm{Fe}^{\mathrm{II}}+\mathrm{Fe}^{\mathrm{III}}$ did not remain constant. In addition, while the ion exchangeable $\mathrm{Fe}^{\mathrm{II}}$ extractions (24) linearly increased with increasing reduction, the values of the adsorbed $\mathrm{Fe}^{\mathrm{II}}$ were too small (Figure 8b). The conclusion that can be drawn from these extractions is similar to what other researchers have suggested: extractions on natural sediments with multiple phases present in small quantities can only be qualitatively assessed with this method. It still appears that the time-consuming process of slowly oxidizing sediment with dissolved oxygen in a column experiment yields the most accurate and consistent results of the mass of reduced iron in dithionite-treated sediments. 

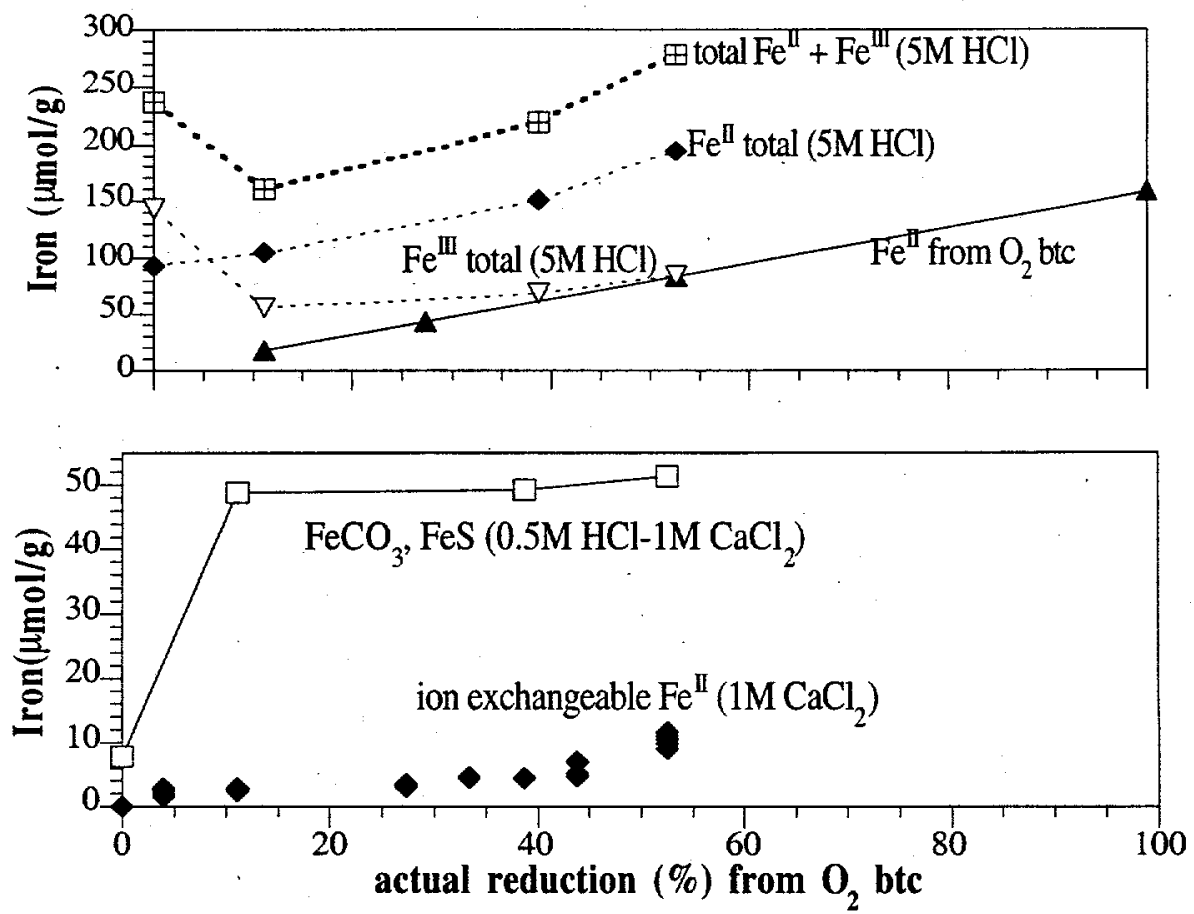

Figure 8. Changes in $\mathrm{Fe}^{\mathrm{ll}}$ and $\mathrm{Fe}^{\mathrm{n}}$ phases as sediment is partially reduced, as characterized by: a) $5 \mathrm{M} \mathrm{HCl}$ extractions that measure total $\mathrm{Fe}^{\mathrm{II}}$ and $\mathrm{Fe}^{\mathrm{II}}$ phases, and b) $1 \mathrm{M} \mathrm{CaCl}_{2}$ for extracting adsorbed $\mathrm{Fe}^{\mathrm{II}}$ and the difference of a $0.5 \mathrm{M} \mathrm{HCl}$ and $1 \mathrm{M} \mathrm{CaCl}_{2}$ to measure $\mathrm{FeCO}_{3}$ and $\mathrm{FeS}$.

The mobility of major and trace metals during sediment reduction and oxidation was measured in effluent samples during reduction (10 pore volumes) and oxidation ( 550 pore volumes) to assess the potential migration of heavy metals that could occur as the redox conditions of the natural (oxic) sediment have been reduced. Metals that increased due to the reducing conditions created (Table 9) included $\mathrm{Fe}, \mathrm{Mn}$, and As, as reduced species of these metals are more mobile under low Eh conditions. The concentrations of $\mathrm{Sn}, \mathrm{Sb}, \mathrm{Zn}$, and $\mathrm{Pb}$ also increased, but these metals may have leached from the sediment regardless of the $\mathrm{Eh}$. For example, there is no thermodynamic correlation of $\mathrm{Pb}$ mobility with redox. Metals that decreased due to the reducing conditions created included $\mathrm{Mg}, \mathrm{Al}$, and $\mathrm{U}$. The concentrations of $\mathrm{Na}, \mathrm{K}, \mathrm{Si}, \mathrm{Ba}$, and $\mathrm{Cr}$ increased, but these were from the injection solution. All of these changes are not considered significant because the highly reducing conditions during dithionite injection that mobilized these metals only occur over 2 to 3 days during a field injection experiment. Analysis of metals mobility during sediment oxidation shows which metals are mobile under reduced conditions, then are immobile under oxic conditions. Of significance are the slight mobility of $\mathrm{Fe}$ and $\mathrm{Mn}$ in the reducing conditions, which become immobilized as the column becomes oxic (Table 10). There were no metals that increased in concentration during the 550 pore volumes of oxidation. Metals that were in the dithionite solution $(\mathrm{Na}, \mathrm{K}, \mathrm{Mg}, \mathrm{Si}, \mathrm{Ba}, \mathrm{Cr})$ decreased during oxidation as species were advected out of the column. The potassium concentration was $25 \%$ of the injection concentration at 1.9 pore volumes, $5 \%$ by 4.8 pore volumes, and $1.8 \%$ by 7.2 pore volumes, which may roughly indicate the remaining carbonate and sulfate from the injection water. 
Table 9. Metal mobility during sediment reduction in columns

\begin{tabular}{|c|c|c|c|c|c|c|c|c|c|c|c|c|c|c|c|c|c|c|c|c|c|c|}
\hline $\begin{array}{c}\text { pore } \\
\text { volumes }\end{array}$ & $\begin{array}{r}\mathrm{Na} \\
\mu \mathrm{g} / \mathrm{ml}\end{array}$ & $\begin{array}{c}* \mathrm{Mg} \\
\mu \mathrm{g} / \mathrm{ml} \\
\end{array}$ & $\begin{array}{c}\mathrm{Al} \\
\mu \mathrm{g} / \mathrm{m} / \\
\end{array}$ & $\begin{array}{c}\text { Si } \\
\mu \mathrm{g} / \mathrm{m} \mathrm{I} \\
\end{array}$ & $\begin{array}{c}* \mathrm{~K} \\
\mu \mathrm{g} / \mathrm{m} \mathrm{I} \\
\end{array}$ & $\begin{array}{c}\mathrm{Ca} \\
\mu \mathrm{g} / \mathrm{ml} \\
\end{array}$ & $\begin{array}{c}\mathrm{Fe} \\
\mu \mathrm{g} / \mathrm{m} \mathrm{I}\end{array}$ & $\begin{array}{c}\mathrm{Cr} \\
\mathrm{ng} / \mathrm{ml}\end{array}$ & $\begin{array}{c}\mathrm{Mn} \\
\mathrm{ng} / \mathrm{ml} \\
\end{array}$ & $\begin{array}{c}\mathrm{Ni} \\
\mathrm{ng} / \mathrm{ml}\end{array}$ & $\begin{array}{c}\mathrm{Cu} \\
\mathrm{ng} / \mathrm{ml}\end{array}$ & $\begin{array}{c}\mathrm{Zn} \\
\mathrm{ng} / \mathrm{ml}\end{array}$ & $\begin{array}{c}\text { As } \\
\mathrm{ng} / \mathrm{m} !\end{array}$ & $\begin{array}{c}\mathrm{Se} \\
\mathrm{ng} / \mathrm{ml}\end{array}$ & $\begin{array}{c}\mathrm{Mo} \\
\mathrm{ng} / \mathrm{ml}\end{array}$ & $\begin{array}{c}\mathrm{Ag} \\
\mathrm{ng} / \mathrm{m} \mathrm{I}\end{array}$ & $\begin{array}{c}\mathrm{Cd} \\
\mathrm{ng} / \mathrm{ml}\end{array}$ & $\begin{array}{c}\mathrm{Sn} \\
\mathrm{ng} / \mathrm{ml}\end{array}$ & $\begin{array}{c}\mathrm{Sb} \\
\mathrm{ng} / \mathrm{ml}\end{array}$ & $\begin{array}{c}\mathrm{Ba} \\
\mathrm{ng} / \mathrm{ml}\end{array}$ & $\begin{array}{c}\mathrm{Pb} \\
\mathrm{ng} / \mathrm{m} \mathrm{I}\end{array}$ & $\begin{array}{c}U \\
\mathrm{ng} / \mathrm{m}\end{array}$ \\
\hline & 3440 & 0.3 & 0.6 & 16.2 & 30300 & 3.43 & $<1$ & 407 & $<10$ & $<5$ & 49.2 & $<10$ & $<20$ & 300 & $10 \pm 5$ & $<2$ & $<2$ & $<2$ & $<2$ & 89.4 & $<2$ & $<2$ \\
\hline 0.5 & 1840 & 97.6 & 0.09 & 13.2 & 12600 & 6.08 & 2.3 & 288 & 2840 & $62 \pm 7$ & $<5$ & 502 & 74.5 & $30 \pm 14$ & 73.3 & $<2$ & $8.0 \pm 3$ & $<2$ & & 9.4 & 154 & 6.2 \\
\hline $\begin{array}{c}2 \\
4.98\end{array}$ & $\begin{array}{l}2900 \\
3780\end{array}$ & $\begin{array}{l}87.4 \\
9.38\end{array}$ & $\begin{array}{l}0.093 \\
0.047\end{array}$ & $\begin{array}{l}12.1 \\
23.0\end{array}$ & $\begin{array}{l}19800 \\
25900\end{array}$ & $\begin{array}{c}8.4 \\
22.4\end{array}$ & $\begin{array}{c}4.5 \\
3.88\end{array}$ & & & & & & & & & & $\begin{array}{l}<2 \\
<2\end{array}$ & & & & $\begin{array}{r}9.8 \\
3 \pm 1\end{array}$ & $\begin{array}{l}6.7 \\
7 \pm 3\end{array}$ \\
\hline $\begin{array}{c}4.98 \\
8\end{array}$ & $\begin{array}{l}3960 \\
3760\end{array}$ & $\begin{array}{c}9.2 \\
3.99\end{array}$ & $\begin{array}{l}0.051 \\
0.023\end{array}$ & $\begin{array}{l}23.0 \\
19.6\end{array}$ & $\begin{array}{l}25500 \\
25300\end{array}$ & $\begin{array}{l}23.8 \\
19.9\end{array}$ & $\begin{array}{l}4.38 \\
3.18\end{array}$ & $\begin{array}{l}191 \\
186\end{array}$ & $\begin{array}{l}16.4 \\
33.1\end{array}$ & $\begin{array}{c}12.9 \\
5.3\end{array}$ & $\begin{array}{l}<5 \\
<5\end{array}$ & $\begin{array}{l}17.9 \\
23.1\end{array}$ & $\begin{array}{l}1010 \\
718\end{array}$ & $\begin{array}{l}<50 \\
<50\end{array}$ & & $\begin{array}{l}<2 \\
<2\end{array}$ & $\begin{array}{l}<2 \\
<2\end{array}$ & & & $\begin{array}{l}144 \\
188\end{array}$ & $\begin{array}{l}<2 \\
<2\end{array}$ & \\
\hline 9.5 & 3050 & 3.2 & $<0.02$ & 12.2 & 29300 & 5.80 & 2.50 & 419 & 6.6 & $<5$ & $<5$ & $12 \pm 5$ & 419 & $44 \pm 13$ & 87.4 & $<2$ & $<2$ & 16.0 & $10 \pm 1$ & 196 & $<2$ & $<2$ \\
\hline
\end{tabular}

Table 10. Metal mobility during sediment oxidation in columns

\begin{tabular}{|c|c|c|c|c|c|c|c|c|c|c|c|c|c|c|c|c|c|c|c|c|c|c|}
\hline $\begin{array}{l}\text { pore } \\
\text { volumes }\end{array}$ & $\begin{array}{l}{ }^{*} \mathrm{Na} \\
\mu \mathrm{g} / \mathrm{mI}\end{array}$ & $\begin{array}{c}* \mathrm{Mg} \\
\mu \mathrm{g} / \mathrm{mI}\end{array}$ & $\begin{array}{c}\mathrm{Al} \\
\mu \mathrm{g} / \mathrm{mI}\end{array}$ & $\begin{array}{c}S 1 \\
\mu \mathrm{g} / \mathrm{m} /\end{array}$ & $\begin{array}{c}* \mathrm{~K} \\
\mu \mathrm{g} / \mathrm{ml}\end{array}$ & $\begin{array}{c}\mathrm{Ca} \\
\mu \mathrm{g} / \mathrm{ml}\end{array}$ & $\begin{array}{c}\mathrm{Fe} \\
\mu \mathrm{g} / \mathrm{ml}\end{array}$ & $\begin{array}{c}C r \\
n g / m l\end{array}$ & $\begin{array}{c}\mathrm{Mn} \\
\mathrm{ng} / \mathrm{ml}\end{array}$ & $\begin{array}{c}\mathrm{NI} \\
\mathrm{ng} / \mathrm{ml}\end{array}$ & $\begin{array}{c}\mathrm{Cu} \\
\mathrm{ng} / \mathrm{ml}\end{array}$ & $\begin{array}{c}Z n \\
n g / m l\end{array}$ & $\begin{array}{c}\text { As } \\
\mathrm{ng} / \mathrm{ml}\end{array}$ & $\begin{array}{c}\mathrm{Se} \\
\mathrm{ng} / \mathrm{ml}\end{array}$ & $\begin{array}{c}\mathrm{Mo} \\
\mathrm{ng} / \mathrm{ml}\end{array}$ & $\begin{array}{c}\mathrm{Ag} \\
\mathrm{ng} / \mathrm{ml}\end{array}$ & $\begin{array}{c}\mathrm{Cd} \\
\mathrm{ng} / \mathrm{ml}\end{array}$ & $\begin{array}{c}\mathrm{Sn} \\
\mathrm{ng} / \mathrm{ml}\end{array}$ & $\begin{array}{c}\mathrm{Sb} \\
\mathrm{ng} / \mathrm{ml}\end{array}$ & $\begin{array}{c}\mathrm{Ba} \\
\mathrm{ng} / \mathrm{ml}\end{array}$ & $\begin{array}{c}\mathrm{Pb} \\
\mathrm{ng} / \mathrm{ml}\end{array}$ & $\begin{array}{c}U \\
\mathrm{~g} / \mathrm{ml}\end{array}$ \\
\hline dithionite & & & & & & & & & & & & & & & & & & & & & & \\
\hline $\begin{array}{l}\text { inj. soln } \\
\text { xidation }\end{array}$ & 3440 & 0.3 & 0.6 & 16.2 & 30300 & 3.43 & $<1$ & 407 & $<10$ & $<5$ & 49.2 & $<10$ & $<20$ & 300 & $10 \pm 5$ & $<2$ & $<2$ & $<2$ & $<2$ & 89.4 & $<2$ & $<2$ \\
\hline nj. soln. & 1.30 & $<0.2$ & $<0.02$ & 0.538 & $<1$ & 4.09 & $<1$ & $<10$ & $<10$ & $<5$ & $<5$ & 3.82 & $<20$ & $<20$ & $<10$ & $<2$ & $<2$ & $<2$ & $<2$ & $<2$ & $<2$ & $<2$ \\
\hline $\begin{array}{l}0.62 \\
1.87\end{array}$ & $\begin{array}{c}3360 \\
722\end{array}$ & $\begin{array}{l}2.28 \\
0.57\end{array}$ & $\begin{array}{c}0.047 \\
0.0413\end{array}$ & $\begin{array}{l}11.3 \\
6.30\end{array}$ & $\begin{array}{l}28700 \\
7560\end{array}$ & $\begin{array}{l}7.74 \\
1.71\end{array}$ & $\begin{array}{c}4.36 \\
<1\end{array}$ & $\begin{array}{l}436 \\
100\end{array}$ & $\begin{array}{l}221 \\
<10\end{array}$ & $\begin{array}{l}5.5 \\
<5\end{array}$ & $\begin{array}{l}<5 \\
<5\end{array}$ & $\begin{array}{c}16 \pm 2 \\
5 \pm 3\end{array}$ & $\begin{array}{l}260 \\
86.7\end{array}$ & $\begin{array}{c}30 \pm 17 \\
<20\end{array}$ & $\begin{array}{l}49 \pm 7 \\
26 \pm 4\end{array}$ & $\begin{array}{l}<2 \\
<2\end{array}$ & $\begin{array}{l}<2 \\
<2\end{array}$ & $\begin{array}{c}12 \pm 2 \\
3.8\end{array}$ & $\begin{array}{c}6.3 \\
3.99\end{array}$ & $\begin{array}{l}180 \\
37.1\end{array}$ & $\begin{array}{l}<2 \\
<2\end{array}$ & $\begin{array}{c}2 \pm 1 \\
<2\end{array}$ \\
\hline $\begin{array}{l}4.8 \\
7.2\end{array}$ & $\begin{array}{r}181 \\
78.3\end{array}$ & $\begin{array}{l}0.290 \\
0.189\end{array}$ & $\begin{array}{l}0.054 \\
0.043\end{array}$ & $\begin{array}{l}3.41 \\
3.07\end{array}$ & $\begin{array}{c}1400 \\
565\end{array}$ & $\begin{array}{l}10.4 \\
10.4\end{array}$ & $\begin{array}{l}0.171 \\
0.098\end{array}$ & $\begin{array}{l}12 \pm 2 \\
12.6\end{array}$ & $\begin{array}{r}3.5 \\
3 \pm 1\end{array}$ & $\begin{array}{l}2.5 \\
3 \pm 1\end{array}$ & $\begin{array}{l}<5 \\
<5\end{array}$ & $\begin{array}{l}14.4 \\
12.9\end{array}$ & $\begin{array}{l}32 \pm 7 \\
21 \pm 7\end{array}$ & $\begin{array}{l}<50 \\
<50\end{array}$ & $\begin{array}{r}7 \pm 1 \\
4.0\end{array}$ & $\begin{array}{l}<2 \\
<2\end{array}$ & $\begin{array}{l}<2 \\
<2\end{array}$ & $\begin{array}{c}4 \pm 1 \\
<2\end{array}$ & $\begin{array}{l}<2 \\
<2\end{array}$ & $\begin{array}{l}14 \pm 2 \\
10.7\end{array}$ & $\begin{array}{l}<2 \\
<2\end{array}$ & $\begin{array}{l}<2 \\
<2\end{array}$ \\
\hline $\begin{array}{c}9.1 \\
21.6 \\
50\end{array}$ & $\begin{array}{l}40.3 \\
7.24 \\
4.31\end{array}$ & $\begin{array}{l}0.172 \\
0.138 \\
0.134\end{array}$ & $\begin{array}{l}0.046 \\
0.066 \\
0.081\end{array}$ & $\begin{array}{l}3.38 \\
3.10 \\
2.69\end{array}$ & $\begin{array}{l}337 \\
92.8 \\
69.9\end{array}$ & $\begin{array}{l}11.7 \\
12.0 \\
11.3\end{array}$ & $\begin{array}{l}0.142 \\
0.147 \\
0.149\end{array}$ & $\begin{array}{l}9 \pm 1 \\
5.8 \\
5 \pm 1\end{array}$ & $\begin{array}{r}2 \pm 1 \\
2.9 \\
4 \pm 1\end{array}$ & $\begin{array}{l}3 \pm 1 \\
2 \pm 1 \\
3 \pm 2\end{array}$ & $\begin{array}{l}<5 \\
<5 \\
<5\end{array}$ & $\begin{array}{c}14.9 \\
11.9 \\
8.9\end{array}$ & $\begin{array}{c}20 \pm 3 \\
11.9 \\
11 \pm 4\end{array}$ & $\begin{array}{l}<50 \\
<50 \\
<50\end{array}$ & $\begin{array}{l}<2 \\
<2 \\
<2\end{array}$ & $\begin{array}{l}<2 \\
<2 \\
<2\end{array}$ & $\begin{array}{l}<2 \\
<2 \\
<2\end{array}$ & $\begin{array}{l}<2 \\
<2 \\
<2\end{array}$ & $\begin{array}{l}<2 \\
<2 \\
<2\end{array}$ & $\begin{array}{l}12.3 \\
13.8 \\
15.1\end{array}$ & $\begin{array}{l}<2 \\
<2 \\
<2\end{array}$ & $\begin{array}{l}<2 \\
<2 \\
<2\end{array}$ \\
\hline $\begin{array}{l}170 \\
550\end{array}$ & $\begin{array}{l}1.76 \\
0.396\end{array}$ & $\begin{array}{l}0.197 \\
0.133\end{array}$ & $\begin{array}{l}0.038 \\
0.203\end{array}$ & $\begin{array}{l}0.9 \\
1.5\end{array}$ & $\begin{array}{l}36.8 \\
9.99\end{array}$ & $\begin{array}{l}7.19 \\
12.2\end{array}$ & $\begin{array}{l}0.058 \\
0.13\end{array}$ & $\begin{array}{l}2 \pm 1 \\
2.3\end{array}$ & $\begin{array}{l}13.4 \\
19.7\end{array}$ & $\begin{array}{l}2 \pm 1 \\
3.8\end{array}$ & $\begin{array}{l}<5 \\
<5\end{array}$ & $\begin{array}{l}7.1 \\
4.1\end{array}$ & $\begin{array}{l}<5 \\
<5\end{array}$ & $\begin{array}{l}<50 \\
<50\end{array}$ & $\begin{array}{l}<2 \\
<2\end{array}$ & $\begin{array}{l}<2 \\
<2\end{array}$ & $\begin{array}{l}<2 \\
<2\end{array}$ & $\begin{array}{l}<2 \\
<2\end{array}$ & $\begin{array}{l}<2 \\
<2\end{array}$ & $\begin{array}{l}13.1 \\
15.4\end{array}$ & $\begin{array}{l}<2 \\
<2\end{array}$ & $\begin{array}{l}<2 \\
<2\end{array}$ \\
\hline
\end{tabular}

"injected with dithionite 
Reactive transport modeling of the general problem of Fe and Mn transport from reduced zones (Smith and Jaffe 1998) confirms the laboratory results of limited $\mathrm{Mn}^{\mathrm{II}}$ movement from the reduced zone. In these simulations, the $\mathrm{Fe}^{\mathrm{II}}$ was generated biotically, and although $\mathrm{Fe}^{\mathrm{II}}$ was highly adsorbed, the mass generated exceeded the number of adsorption sites and $\mathrm{Fe}^{\mathrm{II}}$ migrated downgradient (a process that would not occur with the dithionite injection). Arsenic speciation over a range of redox conditions was also simulated. The $\mathrm{As}^{\mathrm{v}}$ species that dominated oxic waters was arsenate $\left[\mathrm{H}_{3} \mathrm{AsO}_{4}\right]$ and the $\mathrm{As}^{\mathrm{III}}$ species that dominate anoxic waters was arsenite $\left[\mathrm{H}_{3} \mathrm{AsO}_{3}\right]$. Simulations showed that the $\mathrm{As}{ }^{\mathrm{v} / \mathrm{II}}$ species change was sharp during the transport across the redox interface. Although these simulations were not conducted under the specific conditions of a dithionite injection, they do show that species that are mobile in a reduced environment are not mobile outside the localized reduced zone. 



\subsection{Results - TCE Dechlorination}

Batch experiments in this study were conducted in fully reduced sediment to determine the major reaction pathway for TCE dechlorination, reaction products, and dechlorination rate of TCE and various degradation products (Section 5.1). Batch studies were additionally conducted in partially reduced sediment to understand the mechanism at the field scale, where dithionite treatment through wells would result in varied reduction spatially (Section 5.2) and at different temperature (Section 5.3). Finally, reactive transport experiments in 1-D columns were conducted to assess TCE dechlorination during advective transport at field-scale temperatures in fully and partially reduced sediment (Section 5.4).

\subsection{TCE Dechlorination Pathway and Rate}

The pathway by which TCE was degraded by dithionite-reduced sediments was determined in batch experiments. Previous research using Hanford sediments and research by others (see Section 2.3) have shown that TCE is degraded by two major pathways: 1) reductive elimination (TCE $\rightarrow$ chloroacetylene $\rightarrow$ acetylene $\rightarrow$ ethylene $\rightarrow$ ethane), and 2 ) hydrogenolysis (TCE $\rightarrow$ cis-DCE $\rightarrow$ vinyl chloride), with all the mass accounted for by reductive elimination and with possibly a minor $(0.3 \%)$ amount of mass accounted for by hydrogenolysis.

The major pathway for TCE degradation by dithionite-reduced Ft. Lewis sediments was clearly shown to be reductive elimination, which accounted for $99.5 \%$ to $100 \%$ of degraded TCE mass (Figure 9 with detailed plots in Appendix D). A typical batch experiment consisted of a series of vials containing Ft. Lewis groundwater (with $2.7 \mathrm{ppm}$ TCE, Table 6) mixed with Ft: Lewis sediments that were fully reduced with no headspace. Initially all the TCE was in the water, and over time, TCE adsorbed and was degraded. At different time intervals, TCE and degradation products in the water were measured by GC or GC-MS analysis. One experiment (Figure 9) shows TCE decreasing in solution with a half-life of $3.5 \mathrm{~h}$, which corresponds almost exactly to the increase in acetylene mass. There was a slight increase, then decrease, in chloroacetylene at $1 \mathrm{~h}$ to $4 \mathrm{~h}$, indicating that any chloroacetylene produced was quickly degraded to acetylene.

Evidence for the lack of importance of the hydrogenolysis pathway for TCE degradation is shown by the lack of change in the DCE and vinyl chloride data. DCE is present in the Ft. Lewis groundwater at $40 \%$ of the molar concentration of TCE (see Appendix D), and over the course of a $70 \mathrm{~h}$ experiment (KF13), the DCE concentration did not change. Vinyl chloride $(2.4 \mathrm{ppb})$ is initially present in the Ft. Lewis groundwater at approximately $1 \%$ of the TCE mole fraction. During the TCE degradation experiment, vinyl chloride in contact with reduced sediment is rapidly removed from solution within minutes (see Appendix D), leaving $0.18 \mathrm{ppb}$ vinyl chloride in solution initially in this experiment. There is a slight increase in vinyl chloride concentration to $0.46 \mathrm{ppb}$ at $10 \mathrm{~h}$ to $20 \mathrm{~h}$, which may represent evidence of a reaction pathway, although these concentrations are below the detection limits $(0.5 \mathrm{ppb})$ of vinyl chloride. If these data are real, they indicate hydrogenolysis could account for $0.3 \%$ of the degraded TCE mass. The vinyl chloride concentrations decreased to 0.14 ppb by $30 \mathrm{~h}$, which (if real) represent vinyl chloride degradation by the reduced sediment. Column experiments provided similar evidence of the lack of importance of hydrogenolysis (Appendix E, discussed in Section 5.4), in which the vinyl chloride concentration increased to $0.8 \%$ of the TCE mass, in contrast to acetylene, which was $>100 \%$ of the TCE mass (i.e., reductive elimination is the major reaction pathway). 


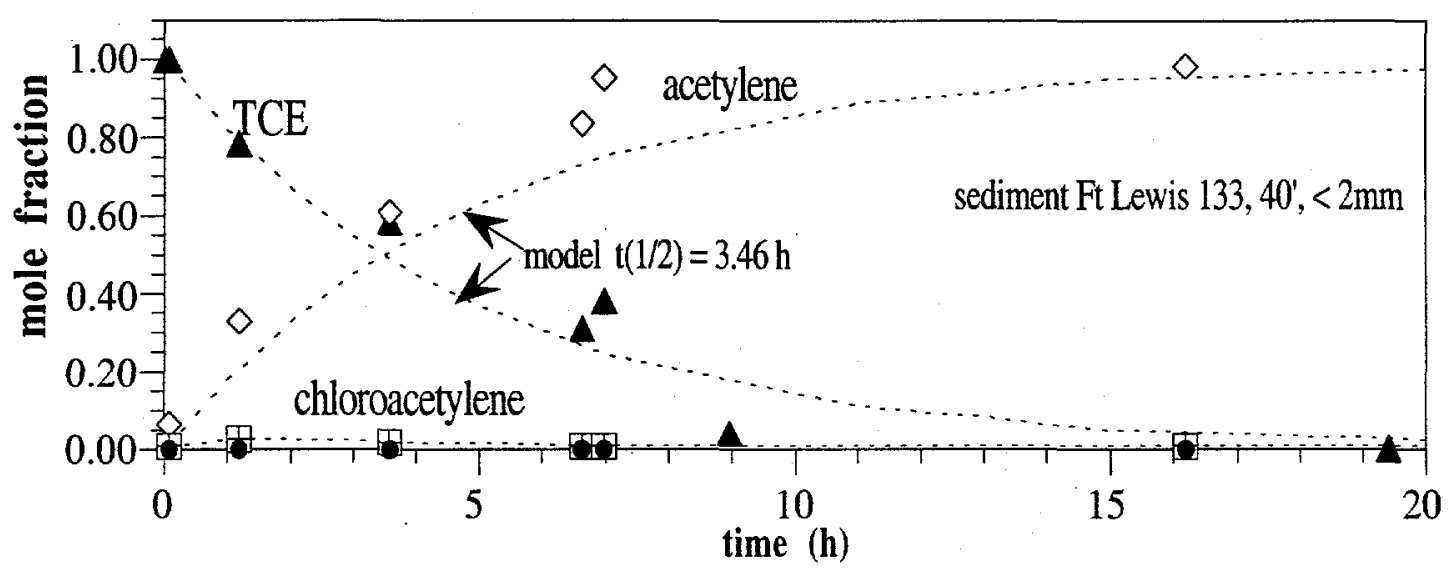

Figure 9. Degradation of $2.7 \mathrm{ppm}$ TCE present in Ft. Lewis groundwater by reduced sediment to chloroacetylene and acetylene indicating reductive elimination is the major reaction pathway.

Although the intrinsic rate of TCE reduction on an iron oxide surface with adsorbed $\mathrm{Fe}^{\mathrm{II}}$ at the molecular scale is the same for different sediments, the observed TCE degradation rate for different sediments varies with the mass of reduced iron. Given that the theoretical mass flux rate for TCE via reductive elimination (Equation 21) is a first-order function of TCE, a third-order function of $\mathrm{H}^{+}$, and a third-order function of $\mathrm{Fe}^{\mathrm{I1}}$, the observed rate for different sediments should vary considerably. For the experiments in this study at fixed $\mathrm{pH}$, the $\mathrm{H}^{+}$term becomes constant. TCE degradation rate data with varying iron content (this and other studies) was used to determine the intrinsic TCE reduction rate and functional dependence on $\mathrm{Fe}^{\Pi}$. The observed TCE degradation rate (reported as first-order half-life, Table 11) varied over an order of magnitude from $0.013 / \mathrm{h}$ (low iron content Hanford sediment) to $0.2 / \mathrm{h}$ (high iron content Ft. Lewis sediment). Assuming a first-order dependence of $\mathrm{Fe}^{\mathrm{II}}$ on the intrinsic TCE degradation rate, the rate variability was reduced to $3 \times(0.0018$ to 0.0054$)$, so is likely the correct dependence:

$$
\mathrm{k}_{\mathrm{f}, \text { intrinsic }}=0.0034 \pm 0.00141 /\left[\mathrm{h} \mu \mathrm{mol} \mathrm{Fe}{ }^{\mathrm{II}}\right]
$$

Assuming a second-order dependence of $\mathrm{Fe}^{\mathrm{II}}$, intrinsic rate values that varied 2.5 orders of magnitude (Table 10), and assuming a third-order dependence of $\mathrm{Fe}^{\mathrm{II}}$, intrinsic rate values that varied 4 orders of magnitude, so were highly likely not the correct dependence of $\mathrm{Fe}^{\mathrm{II}}$ on the intrinsic TCE degradation rate.

Table 11. Dependence of the TCE degradation rate on reduced iron mass

\begin{tabular}{lccccc}
$\begin{array}{c}\text { experiment } \\
\text { name, type }\end{array}$ & $\begin{array}{c}\text { TCE half-life } \\
(\mathrm{hr})\end{array}$ & $\begin{array}{c}\mathrm{Fe}^{\mathrm{Il}} \\
(\mu \mathrm{mol})\end{array}$ & $\begin{array}{c}\text { first-order } \\
\mathrm{k}_{\mathrm{f}} \text { (intrinsic) }\end{array}$ & $\begin{array}{c}\text { second-order } \\
\mathrm{k}_{\mathrm{f}} \text { (intrinsic) }\end{array}$ & $\begin{array}{c}\text { third-order } \\
\mathrm{k}_{\mathrm{f}} \text { (intrinsic) }\end{array}$ \\
\hline Hanford, KE, column & 53.0 & 3.16 & 0.0041 & $1.31 \mathrm{E}-3$ & $4.14 \mathrm{E}-4$ \\
Ft. Lewis, KF13, batch & 3.46 & 37.0 & 0.0054 & $1.46 \mathrm{E}-4$ & $3.95 \mathrm{E}-6$ \\
Moffett, M12, column & 9.4 & 40.9 & 0.0018 & $4.41 \mathrm{E}-5$ & $1.08 \mathrm{E}-6$ \\
Ft. Lewis, KF24, batch & 5.78 & 46.0 & 0.0026 & $5.67 \mathrm{E}-5$ & $1.23 \mathrm{E}-6$ \\
Ft. Lewis, KF17, column & 19.0 & 80.6 & 0.0045 & $5.62 \mathrm{E}-6$ & $6.97 \mathrm{E}-8$ \\
Ft. Lewis,KF23, column & 4.2 & 86.4 & 0.0019 & $2.21 \mathrm{E}-5$ & $2.56 \mathrm{E}-7$ \\
Ft. Lewis, KF42, batch & 1.2 & 333. & 0.0036 & $5.21 \mathrm{E}-6$ & $1.57 \mathrm{E}-8$ \\
\hline
\end{tabular}


The presence of a permeable reduced iron barrier in the groundwater system at $\mathrm{Ft}$. Lewis is capable of degrading organic compounds in addition to TCE. Laboratory studies with reduced Hanford and other sediments have demonstrated that carbon tetrachloride and trinitrotoluene (TNT) are degraded. In this study, there were indications that compounds other than TCE that are present in the Ft. Lewis groundwater were degraded. Column experiment KF23 (Appendix E) clearly showed that TCA was degraded with a half-life of $2.1 \mathrm{~h}$. In this same experiment, GC-MS analysis was used to separate DCE isomers. Although cis-1,2 DCE had an apparent degradation rate of $14 \mathrm{~h}$, the 1,1 DCE (present in trace quantities) did not appear to be degraded. As described earlier in this section, chloroacetylene, acetylene, and ethylene were clearly degraded, and vinyl chloride appeared to be degraded. Although the evidence shows apparent loss of some of these compounds in the reduced sediment, separate degradation experiments of each compound are needed to identify a clear reaction pathway by measurement of one or more reaction products.

\subsection{Influence of Partial Iron Reduction on the TCE Degradation Rate}

Because TCE degradation requires both an electron donor (adsorbed $\mathrm{Fe}^{\mathrm{II}}$ ) and a surface (iron oxide or clay), the rate of dechlorination may not be a simple function of the mass of reduced iron. This fact is significant at the field scale because sediments cannot be uniformly reduced, so studies were conducted to determine the rate of TCE degradation as the reduced iron mass was varied. The mass of reduced iron was measured by oxidizing sediments in columns with dissolved $\mathrm{O}_{2}(\mathrm{Sec}-$ tion 4.3), and the TCE degradation rates (Table 12) were based upon the acetylene data because the TCE mass loss from solution is also affected by adsorption (details in Table 3). A plot of acetylene concentrations of all 15 experiments (Figure 10a, details of each experiment in Appendix D) shows the change in TCE degradation rate with partially reduced sediment.

The TCE degradation rate is highly dependent on the fraction of reduced iron in sediment and varied from $>1000 \mathrm{~h}$ or $11 \%$ reduced to $1.2 \mathrm{~h}$ for $100 \%$ reduced iron. The intrinsic TCE degradation rate varied two orders of magnitude (Table 12), and there appeared to be a significant increase in the TCE degradation rate between $30 \%$ and $45 \%$ reduced sediment (Figure 10a). The intrinsic degradation rate had a second-order dependence on the fraction of reduced iron (line in Figure 10b), which may be caused by the influence of the surface on the TCE degradation rate. These results are consistent with a long-term (4-month) column study with Hanford sediments in which the TCE degradation rate decreased significantly when the sediment was $<50 \%$ reduced.

Table 12. Dependence of the TCE degradation rate on the fraction of reduced iron

\begin{tabular}{lccc} 
sediment color & $\begin{array}{c}\text { reduction } \\
(\%)\end{array}$ & $\begin{array}{c}\text { TCE half-life } \\
\text { (hours) }\end{array}$ & $\begin{array}{c}\mathrm{k}_{\mathrm{f}}, \text { intrinsic, first-order } \\
\left(1 /\left[\mathrm{h} \mu \mathrm{mol} \mathrm{Fe} \mathrm{II}^{\mathrm{II}}\right]\right)\end{array}$ \\
\hline tan & 0.0 & - & - \\
* gray $^{*}$ & 4.0 & - & - \\
$* *$ & 11.1 & 1100 & 0.000034 \\
$* * *$ & 27.4 & 250,216 & 0.000069 \\
$* * * *$ & 33.4 & 120 & 0.00011 \\
$* * * * *$ & 38.7 & 65,50 & 0.00021 \\
$* * * * *$ & 43.8 & 19.2 & 0.00052 \\
$* * * * *$ & 52.6 & 16. & 0.00052 \\
black & 100. & 1.2 & 0.0036
\end{tabular}



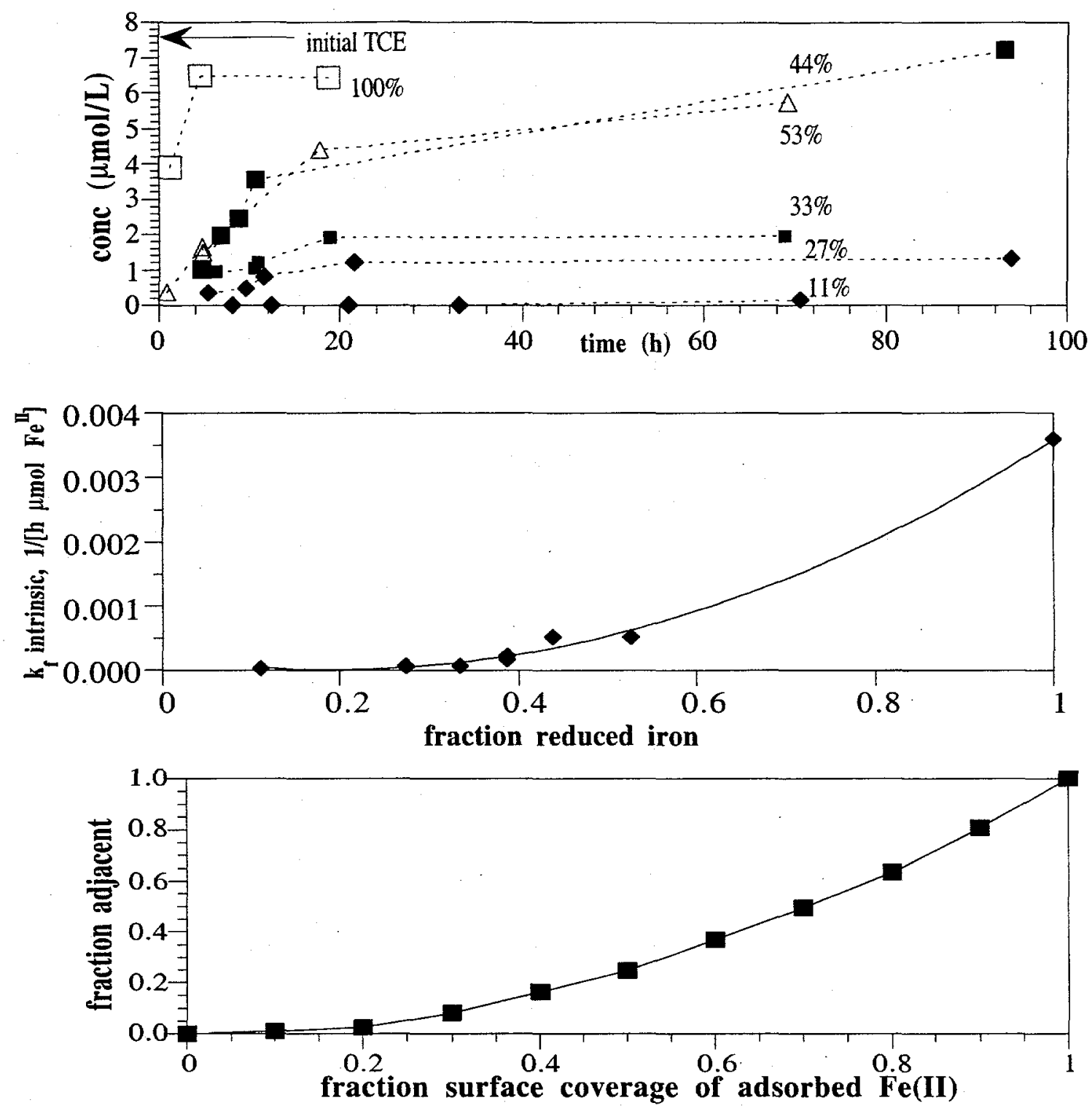

Figure 10. TCE dechlorination rate in partially reduced sediment, as shown by: a) acetylene production rate with differing fraction reduced iron, b) intrinsic TCE dechlorination rate dependence on the fraction of reduced iron, and c) theoretical dependence of adsorbed $\mathrm{Fe}^{\mathrm{II}}$ that are adjacent on a goethite surface as a function of the fraction surface coverage.

The surface coordination of adsorbed $\mathrm{Fe}^{\mathrm{II}}$ on the iron oxide surface is a possible cause of the dependence of the TCE degradation rate on the fraction of iron reduction (see Section 2.4). Because two electrons are needed for TCE dechlorination to chloroacetylene (rxn 12), it was assumed that two adsorbed $\mathrm{Fe}^{\mathrm{II}}$ that were adjacent on a goethite (orthorhombic structure) are needed for the reaction to occur. This surface coordination hypothesis was assessed by probability theory and numerical studies. Results indicated that adjacent sites were a second-order function of the fraction coverage, so at low coverage, there were fewer adjacent sites. For example, if $25 \%$ of the sites were occupied with $\mathrm{Fe}^{\mathrm{II}}$, only $8 \%$ were adjacent and might catalyze TCE dechlorination. In contrast, if $75 \%$ of the sites were occupied with $\mathrm{Fe}^{\mathrm{II}}, 55 \%$ were adjacent. These theoretical results were consistent with and may explain the second-order dependence of the TCE dechlorination rate on sediment reduction fraction, although additional proof is needed. 


\subsection{Temperature Effects on the TCE Dechlorination Rate}

The effect of temperature on the TCE dechlorination rate was investigated because the Ft. Lewis aquifer temperature was significantly colder $\left(12^{\circ} \mathrm{C}\right)$ than laboratory experiments $\left(25^{\circ} \mathrm{C}\right)$. It was hypothesized that because TCE dechlorination was surface catalyzed, the dechlorination rate may not be a simple function of temperature. Batch experiments $\left(2^{\circ} \mathrm{C}\right.$ to $\left.42^{\circ} \mathrm{C}\right)$ with fully reduced $\mathrm{Ft}$. Lewis sediment (Appendix D, Table 3) showed TCE mass decreasing faster than acetylene increased, due to adsorption. The dechlorination rate based on acetylene data (Figure 11a) indicated a regular decrease with lower temperature. In some cases, the acetylene mass produced was greater than the TCE mass consumed. This may be caused by the degradation of other compounds in the Ft. Lewis groundwater. The dependence of the TCE dechlorination rate was $4.00 \mathrm{x}$ slower at $10^{\circ} \mathrm{C}$ compared with $25^{\circ} \mathrm{C}$ (Figure $11 \mathrm{~b}$ ). . Therefore, although TCE dechlorination involves multiple surface reactions, it is apparently a fairly regular function of temperature over the range studied. TCE dechlorination can occur at aquifer temperature at a predictable rate.
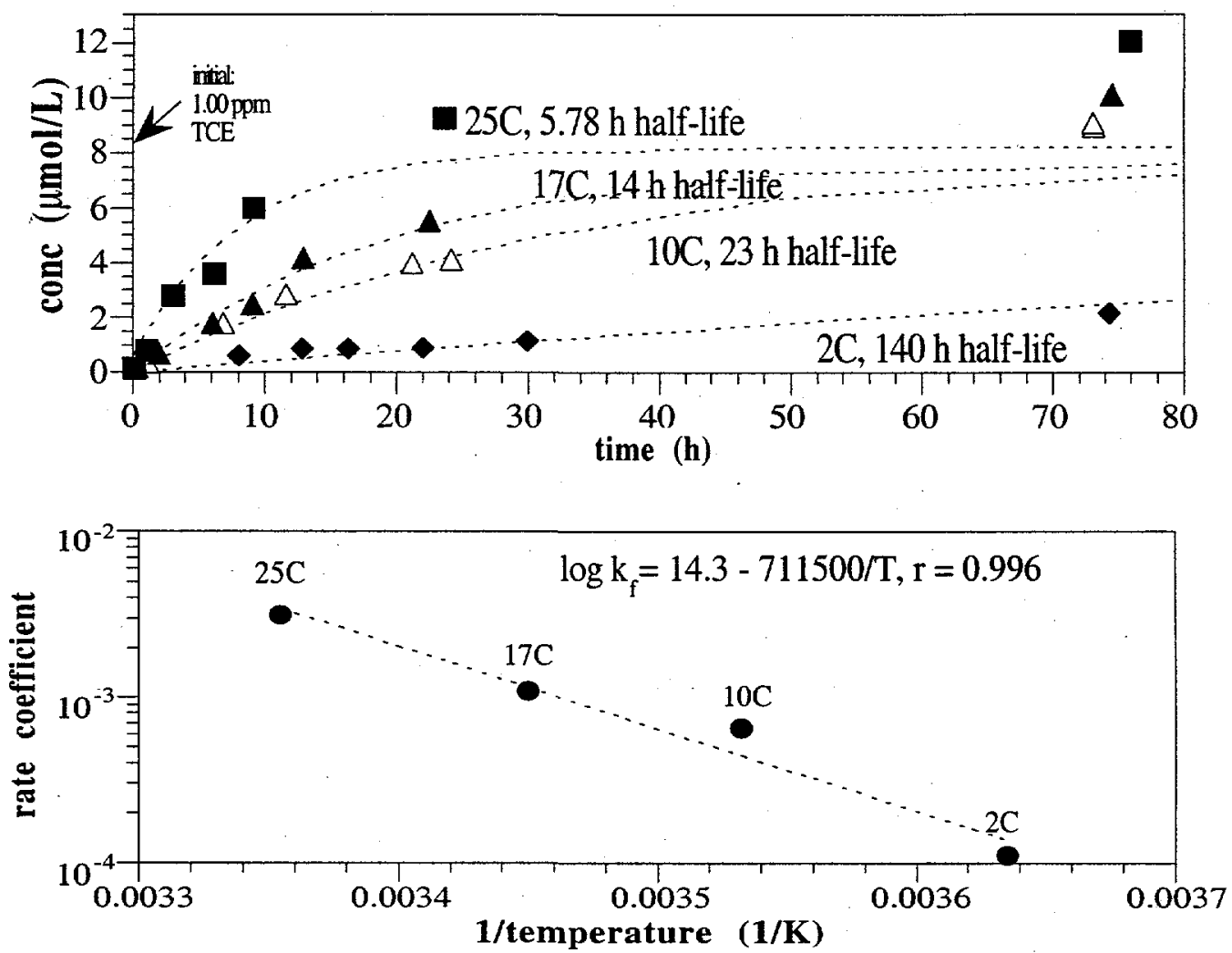

Figure 11. Dechlorination of TCE at different temperature as shown by: a) acetylene production rate over time in experiments at different temperature, and $b$ ) regular dependence of the intrinsic TCE dechlorination rate coefficient with temperature.

\subsection{TCE Dechlorination During Reactive Transport}

The degradation of TCE in Ft. Lewis groundwater was also studied in column experiments to determine if there were additional rate limitations caused in a reactive transport system compared to batch studies. These column experiments were conducted with fully and partially reduced sediment, 
and $10^{\circ} \mathrm{C}$ and $25^{\circ} \mathrm{C}$, to confirm temperature and partial reduction effects quantified in batch systems on TCE dechlorination in flowing systems. A previous long term studies ( $4000 \mathrm{~h}$; Thornton et al. 1998) with Hanford sediment showed: a) the TCE degradation rate slowly decreased as fully reduced sediment was slowly oxidized, b) TCE degradation stopped when the sediment was $\sim 50 \%$ oxidized. Those results are consistent with the partial reduction results of this study (Section 5.2), in which a significant dependence of the fraction-reduced iron on the TCE degradation rate was observed.

One long-term $(1500 \mathrm{~h})$ column experiment was conducted in which the TCE degradation rate was measured as the fully reduced sediment was oxidized. Given that the sediment contains sufficient reducible iron to require 500 pore volumes to fully oxidize the sediment, it is estimated that TCE will be degraded for $\sim 250$ pore volumes. To achieve residence times similar to aquifer conditions, slow flow rates were used. Given these 50 -h to 100 -h residence times for one pore volume in a column, it was not economic to conduct experiments at this rate for 500 pore volumes. Therefore, the flow rate was varied in the column (Figure 12), alternating between slow flow rates to measure the TCE dechlorination (70-h to $100-\mathrm{h}$ residence times), and fast flow rates to oxidize sediment (0.3-h residence time).
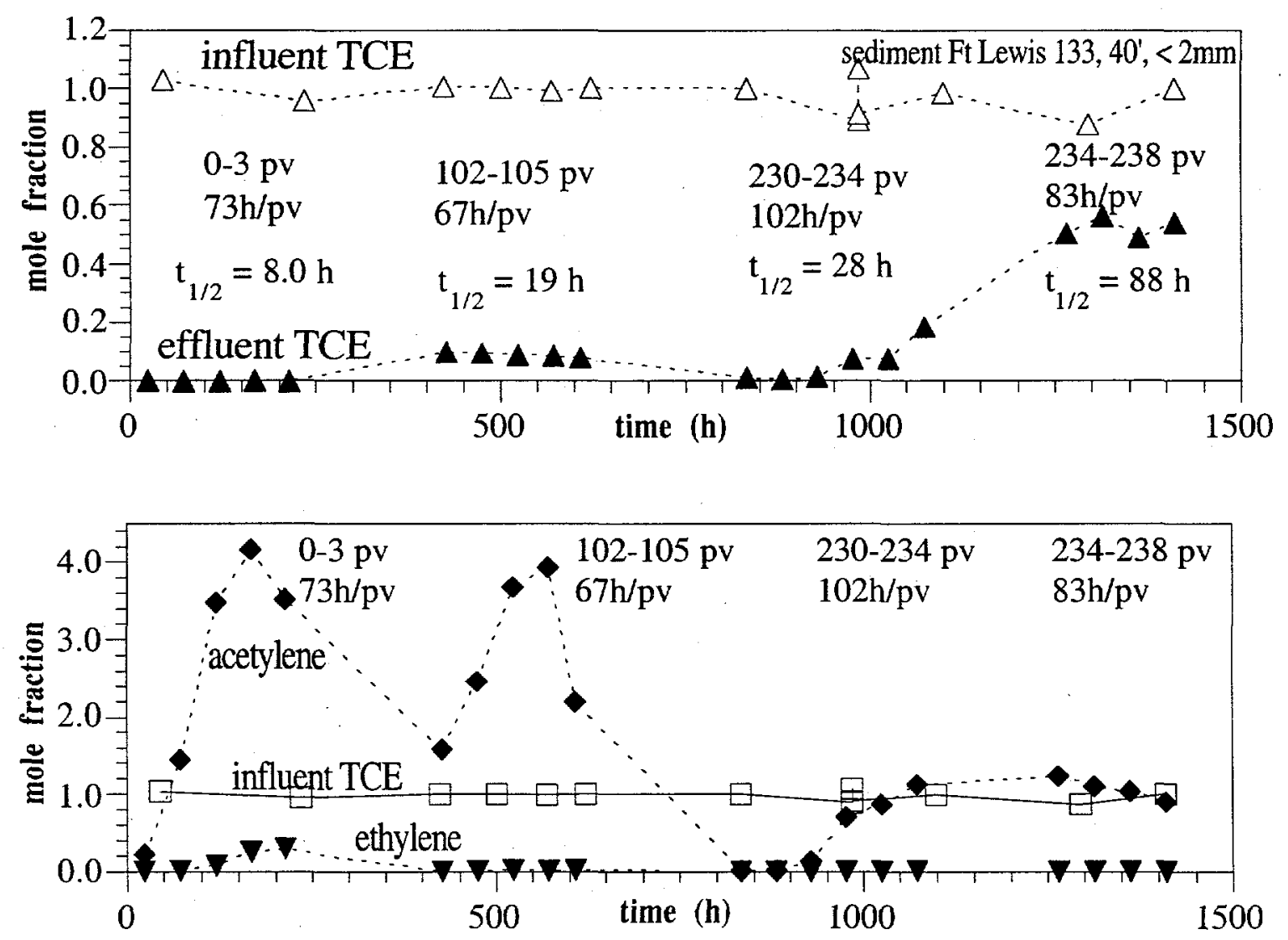

Figure 12. TCE dechlorination in a long-term column experiment as sediment is slowly oxidized, as shown by: a) TCE influent and effluent, and b) acetylene and ethylene. 
Results of this long-term experiment indicate that TCE dechlorination rates achieved in flowing porous media systems are equal or slower than in batch systems. TCE was dechlorinated for $1000 \mathrm{~h}$ (230 pore volumes, Figure $12 \mathrm{a}$ ) at rates that were initially the same as batch experiments, but slowly decreased (Table 10). The acetylene data in this experiment peaked at $4 \mathrm{x}$ the molar concentration of TCE, indicating degradation of other compounds and suggested that the transport of acetylene involved additional processes other than advection in water (Figure 12b). Integration of the area of produced acetylene with $\sim 1.8 \mathrm{x}$ the area of TCE consumed clearly indicated that other compounds were being dechlorinated. It was hypothesized that significant acetylene can be transported in bubbles, which may have contributed to the peak acetylene concentrations observed. The dechlorination rate decreased significantly by 235 pore volumes (Figure 12a) as sediment became partially oxidized. An additional column experiment conducted with Ft. Lewis sediment with significantly higher iron content (KF23, Appendix E) also had a slightly slower TCE dechlorination rate relative to batch experiments (Table 11).

Column experiment results showed considerable TCE mass loss with a corresponding increase in degradation products clearly illustrated the importance of reductive elimination was the major (and essentially only) reaction pathway. Reductive elimination was evident from the significant masses of acetylene and ethylene (and traces of chloroacetylene) in the long-term experiment. The lack of importance of the hydrogenolysis reaction pathway was shown by only a trace increase in vinyl chloride concentration (Appendix E, KF23), and the decrease in 1,2-DCE concentration in reduced sediment (instead of an increase).

To determine the effect of partial reduction on TCE dechlorination under aquifer conditions (flowing system, $10^{\circ} \mathrm{C}$ ), two column experiments were conducted that differed in the spatial distribution of reduced iron. In one experiment (KF39, Appendix E), $10 \mathrm{~g}$ of fully reduced sediment was mixed with $30 \mathrm{~g}$ of untreated sediment to achieve " $25 \%$ reduced" sediment. At the molecular scale, particles that contained adsorbed $\mathrm{Fe}^{\mathrm{II}}$ were adjacent, so this sediment should be able to dechlorinate TCE. In a second experiment (KF 38, Appendix E), sediment was $25 \%$ partially reduced, so would likely not contain sufficient adjacent adsorbed $\mathrm{Fe}^{\mathrm{ll}}$ (see Figure 10 and associated text). Subsequent batch studies showed that the stoichiometric proportions of dithionite to iron used in this experiment would have yielded $<10 \%$ reduced iron. Results of these two column experiments both removed some TCE from solution, although only the experiment with a fraction of fully reduced iron (KF39) produced any acetylene. These results confirmed results of batch experiments that partially reduced sediment is significantly less efficient at degrading TCE. The effect of temperature was small ( $4 \mathrm{x}$ slower at $10^{\circ} \mathrm{C}$ ) relative to the effect of the partial reduction. 



\subsection{Conclusions}

Bench-scale studies were conducted to ascertain how effectively Ft. Lewis sediments can be chemically reduced, and how efficiently the reduced sediment can degrade TCE. The effects of temperature, partial iron reduction, and flow on these redox reactions were also studied to ascertain how to achieve viable TCE dechlorination rates at the field scale.

The fraction of reducible iron in Ft. Lewis sediments was more than sufficient to create an effective reduced zone in the aquifer. The average reducible iron for aquifer sediments at the field site was $63 \pm 40 \mu \mathrm{mol} / \mathrm{g}$ or $0.35 \pm 0.22 \%$, which indicates that the reduced zone would last for 300 pore volumes of oxygen-saturated water (assuming $\mathrm{O}_{2}$ is the only electron acceptor) or longer in the sub-oxic water present at Ft. Lewis. The reduced iron was mainly ( $80 \%$ to $100 \%$ ) adsorbed $\mathrm{Fe}^{\mathrm{II}}$, with the remainder $\mathrm{Fe}^{\mathrm{II}} \mathrm{CO}_{3}$. Iron was reduced rapidly at short times (half-life $3.5 \mathrm{~h}$ in batch, $6.8 \mathrm{~h}$ in columns) and more slowly at later times because the reaction is a third-order function of dithionite and iron concentrations. First-order modeling of reduction would well predict the first half of reduction, but underpredict dithionite use for high fractions of reduction. The relative rates of iron reduction and disproportionation controlled the sediment-dithionite contact times needed to efficiently reduce $80 \%$ of the iron in sediment: $32 \mathrm{~h}$ at $25^{\circ} \mathrm{C} ; 100 \mathrm{~h}$ at $12^{\circ} \mathrm{C}$ (ambient aquifer temperature), and $140 \mathrm{~h}$ at $10^{\circ} \mathrm{C}$. Reduction of $>80 \%$ of the iron is highly inefficient because of dithionite use for disproportionation at long contact times. To reduce $80 \%$ of the iron, $30 \%$ extra dithionite is needed for disproportionation at any temperature. At the field scale, dense (concentrated) dithionite solutions were slumping and not allowing sufficient contact times for reduction. The combination of heated injections at higher velocity and lower dithionite concentration are currently being evaluated at the field scale to achieve aquifer zone reductions.

There was a significant effect of altering the $\mathrm{pH}$ buffer concentration used in dithionite treatment on reduction efficiency, iron mobility, and $\mathrm{pH}$ change. Although 4 moles of $\mathrm{H}^{+}$are generated per mole of dithionite consumed (and the $\mathrm{K}_{2} \mathrm{CO}_{3}$ buffer is typically $4 \mathrm{x}$ the dithionite concentration), the sediment may contribute some buffering capacity. With the same dithionite concentration and contact time, sediment reduced in $3 \mathrm{x}$ buffer had $40 \%$ less reduced iron, and sediment reduced in $0.5 \mathrm{x}$ buffer had $70 \%$ less reduced iron. Less $\mathrm{pH}$ buffer resulted in a low $\mathrm{pH}$ front in columns, which dipped from 9.5 to 3.3 ( $0.5 \mathrm{x}$ buffer) and mobilization of iron: $3.3 \%$ with the $0.5 \mathrm{x}$ buffer compared with $0.02 \%$ with the $4 \mathrm{x}$ buffer. These results indicate the $\mathrm{K}_{2} \mathrm{CO}_{3}$ concentration should be $4 \mathrm{x}$ the dithionite concentration to create an immobile reduced iron zone.

Dithionite-reduced Ft. Lewis sediments have been shown to degrade TCE in Ft. Lewis groundwater at a sufficiently fast rate during reactive transport that a successful permeable barrier could be made at the field scale. Degradation rates observed with different sediments ranged from $1.2 \mathrm{~h}$ to $19 \mathrm{~h}$ (expressed as a half-life for TCE). The TCE degradation rate can be calculated for all sediments from the product of the intrinsic degradation rate $(0.0034 / \mathrm{h} \mu \mathrm{mol})$ and the mass of reduced iron (range of 12 to $126 \mu \mathrm{mol} / \mathrm{g}$; average $=63 \mu \mathrm{mol} / \mathrm{g}$ ). Products of TCE dechlorination clearly show that $99.5 \%$ to $100 \%$ is occurring via reductive elimination, producing acetylene, ethylene, and chloroacetylene. The $2.4 \mathrm{ppb}$ vinyl chloride in Ft. Lewis groundwater quickly decreased in contact with reduced sediment, then increased slightly at $10 \mathrm{~h}(0.18 \mathrm{ppb}$ to $0.46 \mathrm{ppb}$; below detection limits) which may represent the hydrogenolysis reaction pathway. If real, hydrogenolysis could account for, at most, $0.3 \%$ of the TCE mass degraded. Experiments also showed that the reduced sediment degraded other compounds (TCA, chloroacetylene, acetylene, and ethylene), and possibly cis-1,2 DCE and vinyl chloride, although further studies are needed. 
The TCE degradation rate decreased three orders of magnitude in partially reduced sediment, which has significant implications because uniform full sediment reduction is not possible at the field scale. Although minimally reduced sediment had nearly no TCE reactivity, $>40 \%$ reduced sediment resulted in TCE reduction rates that were viable at the field-scale $(<65 \mathrm{~h})$. The second-order dependence of the TCE dechlorination rate on the fraction of reduced iron demonstrates the significant role of the iron oxide surface (as a catalyst or for surface coordination) in addition to $\mathrm{Fe}^{\mathrm{Il}}$ as the electron donor for TCE dechlorination. Calculation of the fraction of adjacent $\mathrm{Fe}^{\mathrm{II}}$ atoms (providing the two electrons needed for TCE dechlorination) on an iron oxide surface resulted in a second-order dependence which was consistent with the trend in the TCE degradation rate data change over fraction of reduced iron. Although the TCE dechlorination is surface catalyzed, the dependence on temperature was predictable, with a $4 x$ slower rate at $10^{\circ} \mathrm{C}$ compared with $25^{\circ} \mathrm{C}$.

Advection resulted in a small decrease in the TCE degradation rate relative to batch experimental results, likely due to diffusional (mixing) limitations in porous media systems. Reduced sediment barrier longevity was demonstrated in a column in which TCE was degraded for over 230 pore volumes. The design of a field-scale reduced iron barrier should be wide enough to allow the TCE to be degraded to below the MCL during the groundwater transport time through the barrier ( $>10$ halflives or $50 \mathrm{~h}$ to $100 \mathrm{~h}$ ), assuming no physical or chemical heterogeneities. Because few sites are homogeneous, barriers are typically designed wider than needed to account for the spatial variability in the iron content and the velocity variability resulting from hydraulic conductivity variability and temporal changes. 


\subsection{References}

Balko, B., and P. Tratnyek. 1998. Photoeffects on the Reduction of Carbon Tetrachloride by ZeroValent Iron, J. Phys. Chem. 102(8):1459-1465.

Blowes, D., C. Ptacek, and J. Jambor. 1997. In Situ Remediation of Cr(VI) Contaminated

Groundwater Using Permeable Reactive Walls: Laboratory Studies, Env. Sci. Technol. 31(12):33483357.

Buerge, I. J., and S. J. Hug. 1997. Kinetics and pH Dependence of Chromium(VI) Reduction by Iron(II), Environ. Sci. Technol. 31(5):1426-1432.

Chao, T. T., and L. Zhou. 1983. Extraction Techniques for Selective Dissolution of Amorphous Iron Oxides from Soils and Sediments, J. Soil Science Society of America, 47:225-232.

Delavarenne, S., and H. Viehe. 1969. Chemistry of Acetylenes, Marcel Dekker, New York, p 651750.

Eary, L., and D. Rai. 1988. Chromate Removal from Aqueous Wastes by Reduction with Ferrous Ion, Environ. Sci. and Technol. 22:972-977.

Fruchter, J., C. Cole, Williams, M., V. Vermeul,, J. Amonette, J. Szecsody, J. Istok and M. Humphrey, Creation of a Subsurface Permeable Treatment Barrier Using In Situ Redox Manipulation, 2000, Groundwater Monitoring Review, in press.

Genin, J., G. Bourrie, F. Trolard, M. Amdelmoula, A. Jaffrezic, P. Refait, V. Maitre, B. Humbert, and A. Herbillon. 1998. Thermodynamic Equilibria in Aqueous Suspensions of Synthetic and Natural $\mathrm{Fe}^{\mathrm{II}}-\mathrm{Fe}^{\mathrm{III}}$ Green Rusts: Occurrences of the Mineral in Hydromorphic Soils, Environ. Sci. Technol. 32:1058-1068.

Heron, G., and T. H. Christensen. 1995. Impact of Sediment-Bound Iron on Redox Buffering in a Landfill Leachate Polluted Aquifer. Environ. Sci. Technol. 29:187-192.

Heron, G., C. Crouzet, A. C. Bourg, and T. H. Christensen. 1994a. Speciation of $\mathrm{Fe}^{\mathrm{II}}$ and $\mathrm{Fe}^{111}$ in Contaminated Aquifer Sediments Using Chemical Extraction Techniques. Environ. Sci. Technol. 28:1698-1705.

Heron, G., T. H. Christensen, and J. Tjell. 1994b. Oxidation Capacity of Aquifer Sediments. Environ. Sci. Technol. 28:153-158.

Istok, J.D., Amonette, J.E., Cole, C.R., Fruchter, J.S., Humphrey, M.D., Szecsody, J.E., Teel, S.S., Vermeul, V.R., Williams, M.D., and Yabusaki, S.B. 1999. In Situ Redox Manipulation by Dithionite Injection: Intermediate-Scale Laboratory Experiments. Groundwater, 37:884-889.

Johnson, T., W. Fish, Y. Gorby, and P. Tratnyek. 1998. Degradation of Carbon Tetrachloride: Complexation Effects on the Oxide Surface, J. Cont. Hyd. 29:379-398.

Orth, W., and R. Gillham. 1996. Dechlorination of Trichloroethene in Aqueous Solution Using $\mathrm{Fe}^{\circ}$, Environ. Sci. Technol. 30(1):66-71. 
Roberts, A., L. Totten, W. Arnold, D. Burris, and T. Campbell. 1996. Reductive Elimination of Chlorinated Ethylenes by Zero-Valent Metals, Environ. Sci. Technol. 30(8):2654-2659.

Seaman, J. C., P. M. Bertsch, and L. Schwallie. 1999. In Situ Cr(VI) Reduction within CoarseTextured, Oxide Coated Soil and Aquifer Systems Using Fe ${ }^{\text {II }}$ Solutions, Environmental Science and Technology 33(6):938-944.

Scherer, M., B. Balko, and P. Tratnyek. 1999. The Role of Oxides in Reduction Reactions at the Metal-Water Interface, in Kinetics and Mechanisms of Reactions at the Mineral/Water Interface, eds D. Sparks and T. Grundl, ACS Symposium Series \#715, American Chemical Society, Atlanta, Georgia, p 301-322.

Sivavec, T., and D. Horney. 1995. Reductive Dechlorination of Chlorinated Ethenes by Iron Metal and Iron Sulfide Minerals, in Emerging Technologies in Hazardous Waste Management VII, p. $42-$ 45. American Chemical Society, Atlanta, Georgia.

Sivavec, T., P. Mackenzie, D. Horney, and S. Baghel. 1996. Redox-Active Media for Permeable Reactive Barriers, research report, General Electric Research and Development Center, Schenectady, New York, p. 753-759.

Smith, S., and P. Jaffe. 1998. Modeling the Transport and Reaction of Trace Metals in WaterSaturated Soils and Sediments, Water Res. Res. 34(11):3135-3147.

Szecsody, J., and R. C. Bales. 1989. Sorption Kinetics of Hydrophobic Organic Compounds on Surface Modified Silica: J. Contaminant Hydrol. 4:181-203.

Szecsody, J., A. Chilikapati, J. Zachara, and A. Garvin. 1998a. Influence of Iron Oxide Lens Shape on CoII/IIIEDTA Reactive Transport Through Spatially Heterogeneous Sediment, Water Res. Res. 25(10):2501-14.

Szecsody, J., A. Chilikapati, J. Zachara, P. Jardine, and A. Ferrency. 1998b. Importance of Flow and Particle-Scale Heterogeneity on CoII/IIIEDTA Reactive Transport, J. Hydrology 209(1-4):112-136.

Szecsody, J., K. Cantrell, K. Krupka, C. Resch, M. Williams, and J. Fruchter. 1998c. Uranium Mobility during In Situ Redox Manipulation of the 100 Areas of the Hanford Site. PNNL-12048, Pacific Northwest National Laboratory, Richland, Washington.

Szecsody, J. E., A. Chilakapati, J. M. Zachara, K. M. Salvage, and G. T. Yeh. 1995. Experimental and simulation results of reactive transport of $\mathrm{Co}(\mathrm{II} / \mathrm{III}) \mathrm{EDTA}$ at variable $\mathrm{pH}, \mathrm{EOS}$, American Geophysical Union, 76(46):221

Thornton, E., J. Szecsody, K. Cantrell, C. Thompson, J. Evans, J. Fruchter, and A. Mitroshkov. 1998. Reductive Dechlorination of TCE by dithionite, in Physical, Chemical, and Thermal Technologies for Remediation of Chlorinated and Recalcitrant Compounds, ed. G. Wickromanayake and R. Hinchee, p. $335-340$.

Wehrli, B. 1992. Redox Reactions of Metal Ions at Mineral Surfaces, in Aquatic Chemical Kinetics, ed. W. Stumm, Wiley Interscience, New York.

Williams, M., Szecsody, J., 1997. Chemical/Physical Controls on the Chemical Reduction and Oxidation Rates of Fe-containing Sediments, American Geophysical Union, EOS, 78(46):H322. 
Appendix A

Batch Reduction Experiments 
KF30: Iron Reduction at $2 \mathrm{C}, 0.11 \mathrm{~mol} / \mathrm{L}$ Dithionite

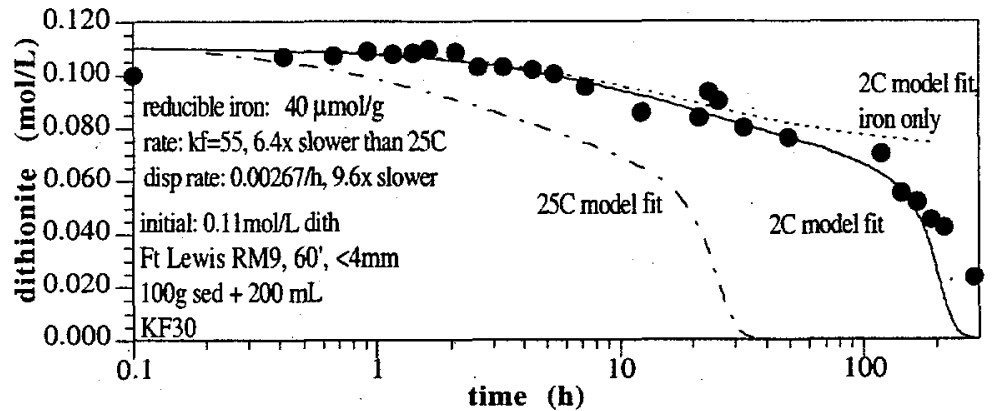

KF30 Simulation: Iron Reduction at 2C

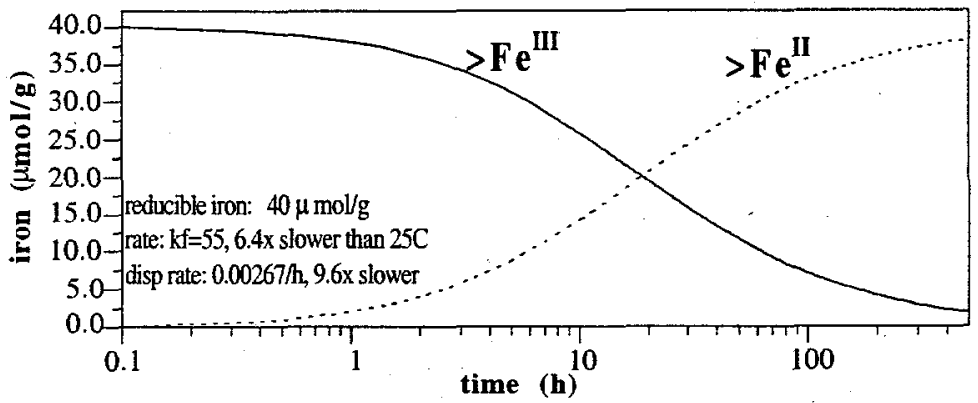

KF31: Iron Reduction at $42 \mathrm{C}, 0.08 \mathrm{~mol} / \mathrm{L}$ Dithionite

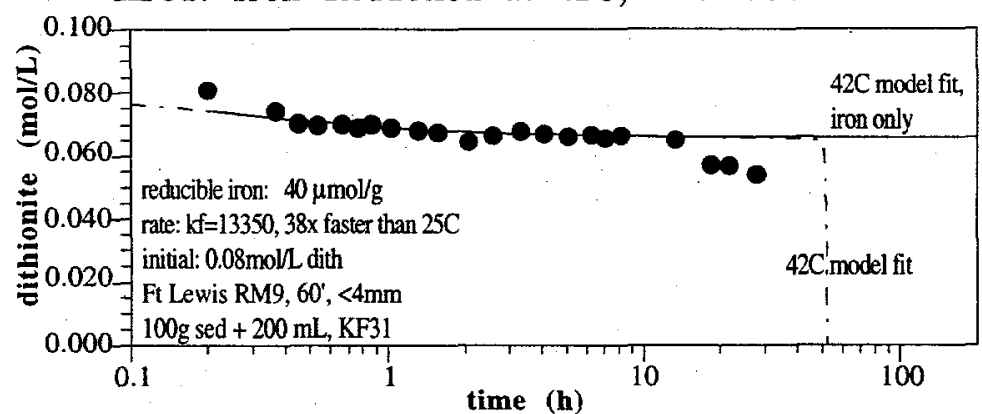

KF32: Iron Reduction vs Dithionite Concentration

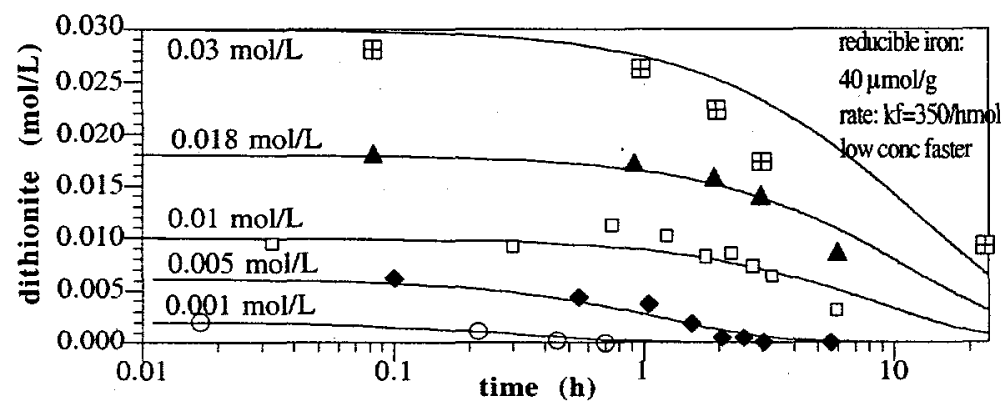

A. 1 


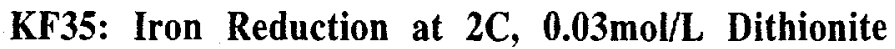

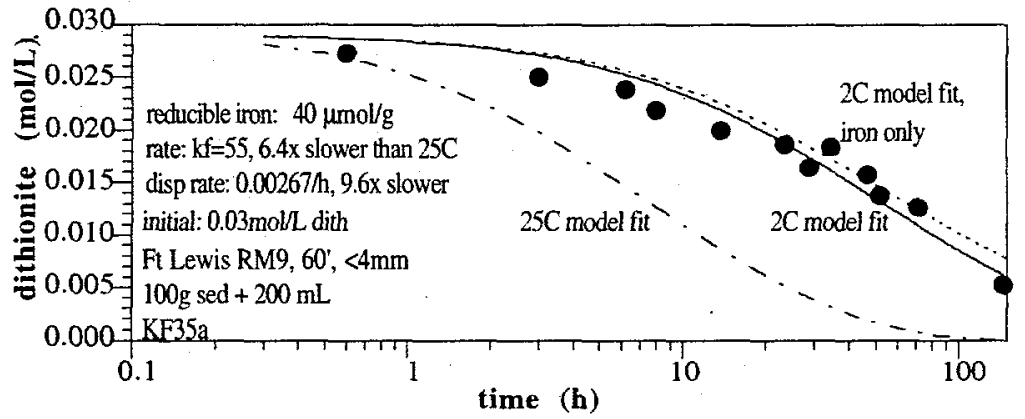

KF36: Iron Reduction at $42 \mathrm{C}, 0.008 \mathrm{~mol} / \mathrm{L}$ Dithionit

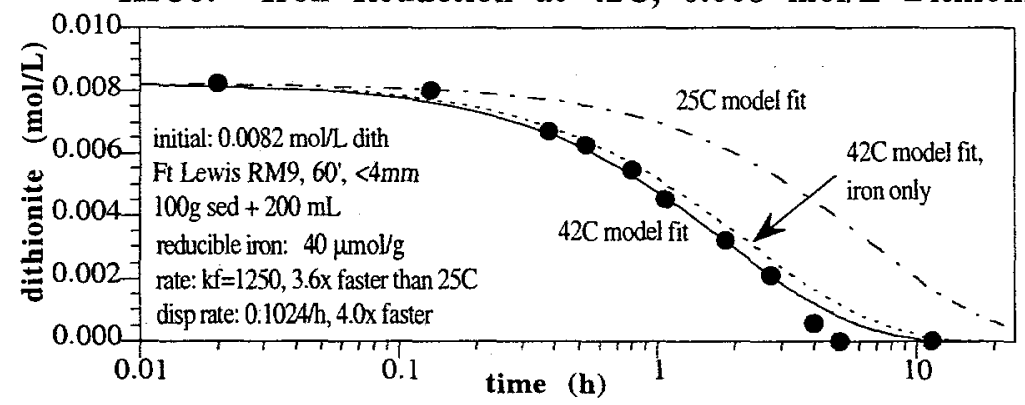

KF37: Iron Reduction at $10 \mathrm{C}, 0.008 \mathrm{~mol} / \mathrm{L}$ Dithionite

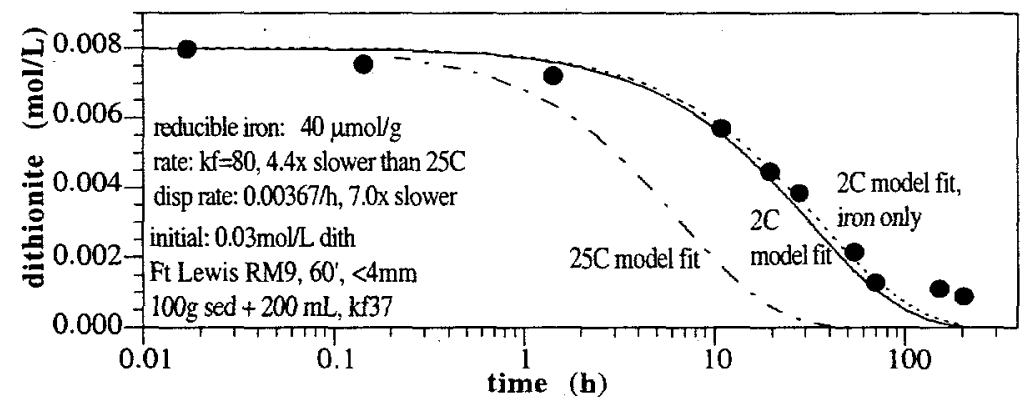




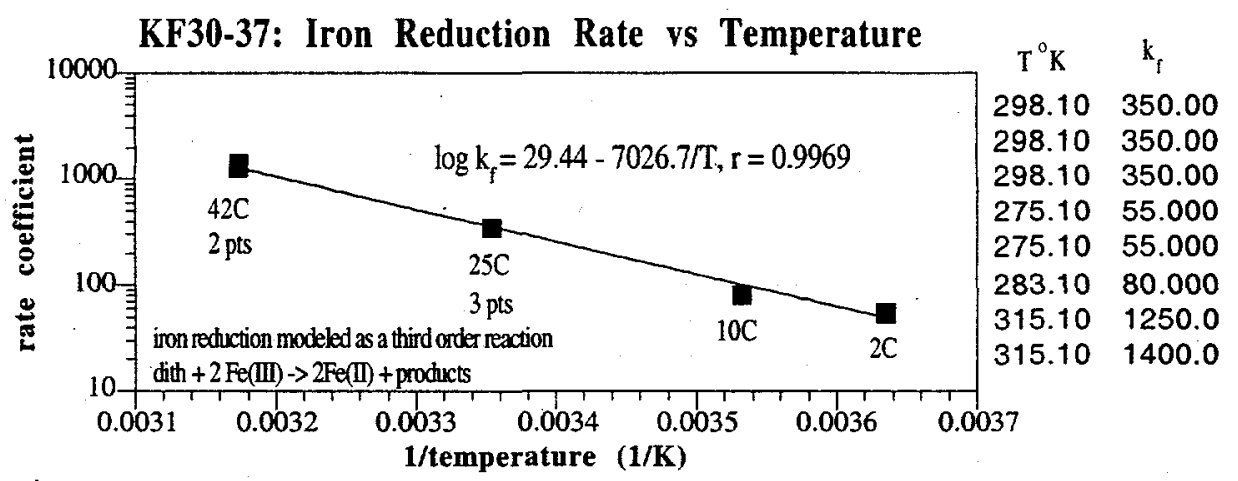

KF30-37: Disproportionation Rate vs Temperature

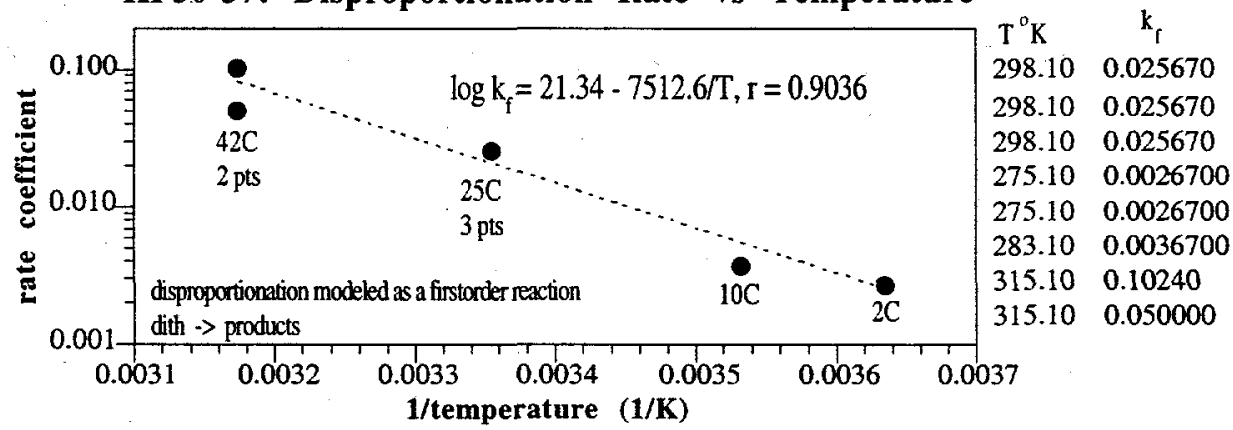

Simulation of Dithionite Removal from Iron Reduction, 2 to $42 \mathrm{C}$

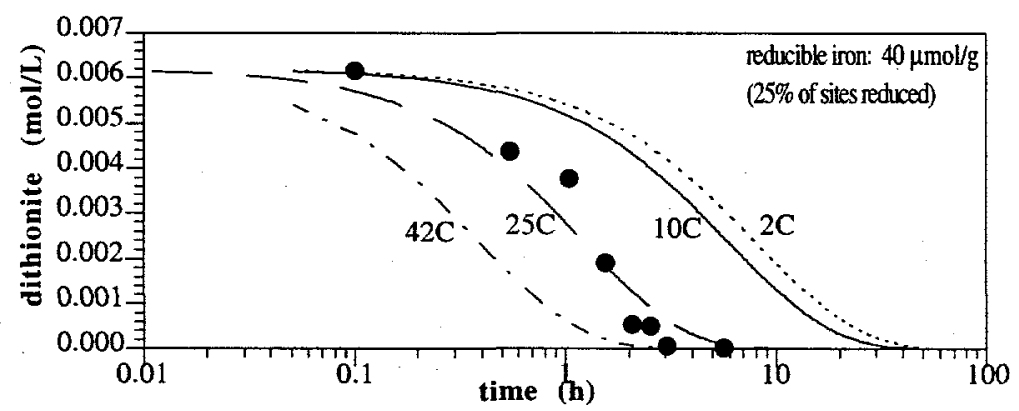

Iron Reduction at $2 \mathrm{C}$ to $42 \mathrm{C}$

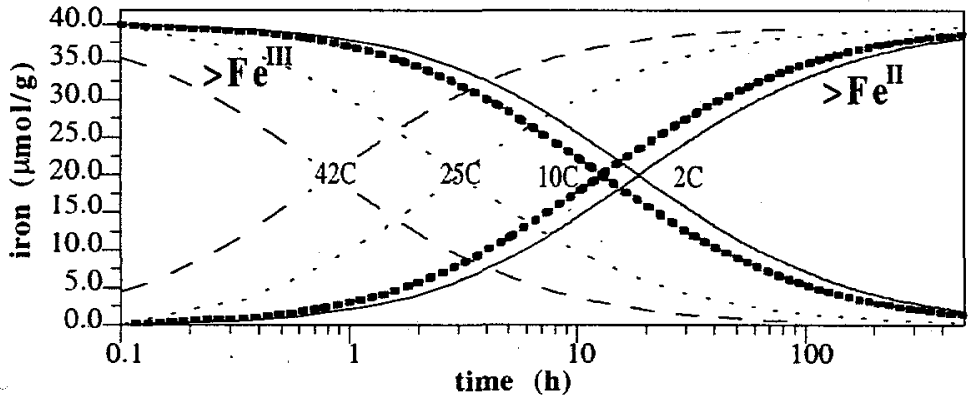


Appendix B

Column Reduction Experiments 
Ft Lewis KF1: Dithionite for $0.09 \mathrm{M}$ dith $+0.36 \mathrm{M} \mathrm{K} \mathrm{CO}_{3}$ inject

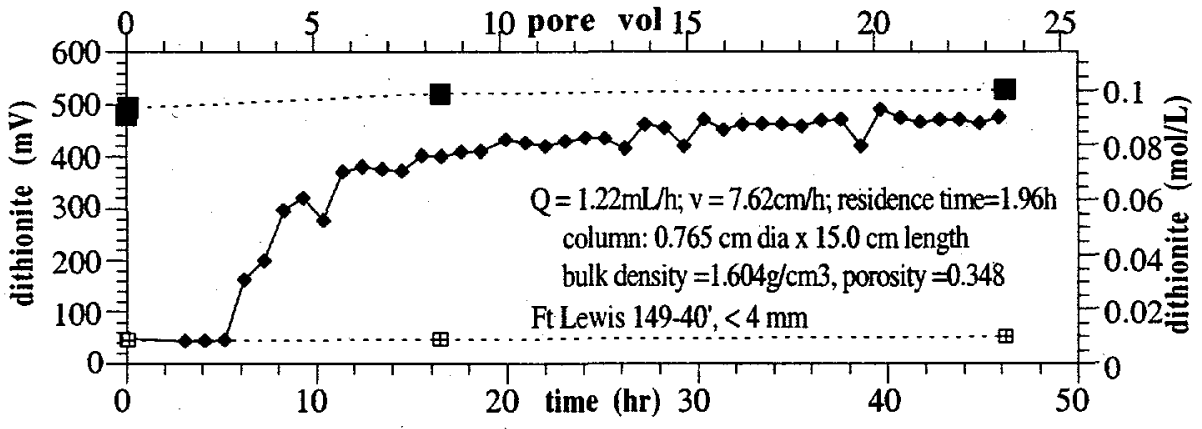

Ft Lewis KF2: Dithionite for $0.09 \mathrm{M}$ dith $+0.36 \mathrm{M} \mathrm{K}_{2} \mathrm{CO}_{3}$ inject

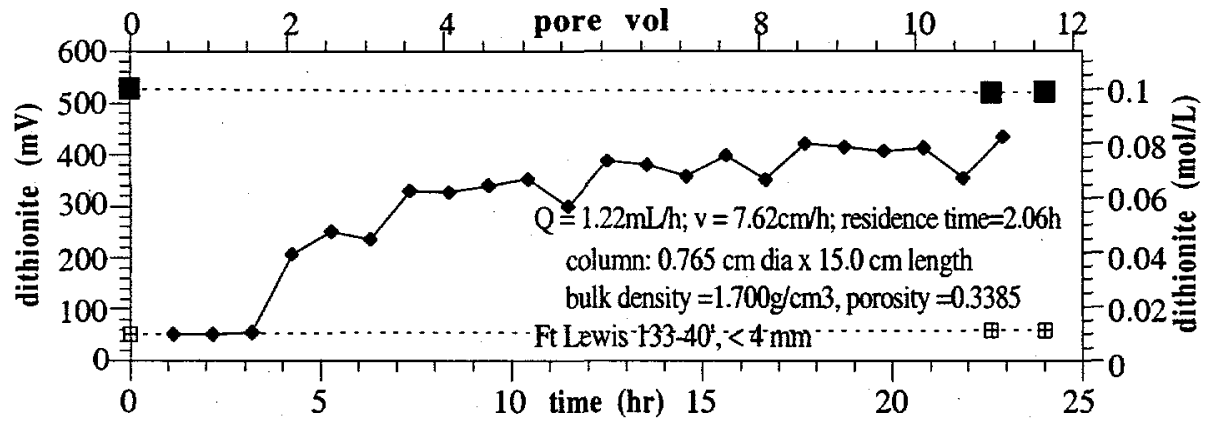

Ft Lewis KF5: Dithionite for $0.09 \mathrm{M}$ dith $+0.36 \mathrm{M} \mathrm{K}_{2} \mathrm{CO}_{3}$ inject

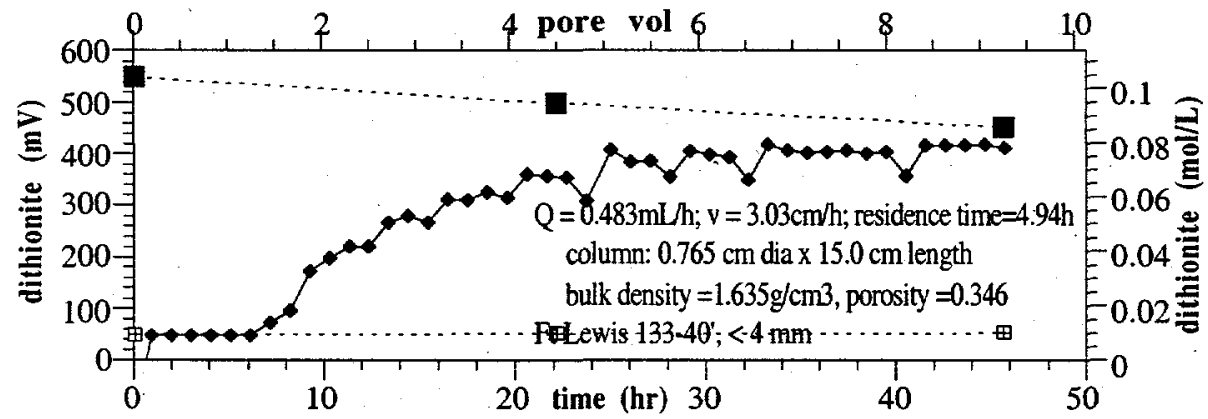

Ft Lewis KF6: Dithionite for $0.09 \mathrm{M}$ dith $+0.36 \mathrm{M} \mathrm{K}_{2} \mathrm{CO}_{3}$ inject

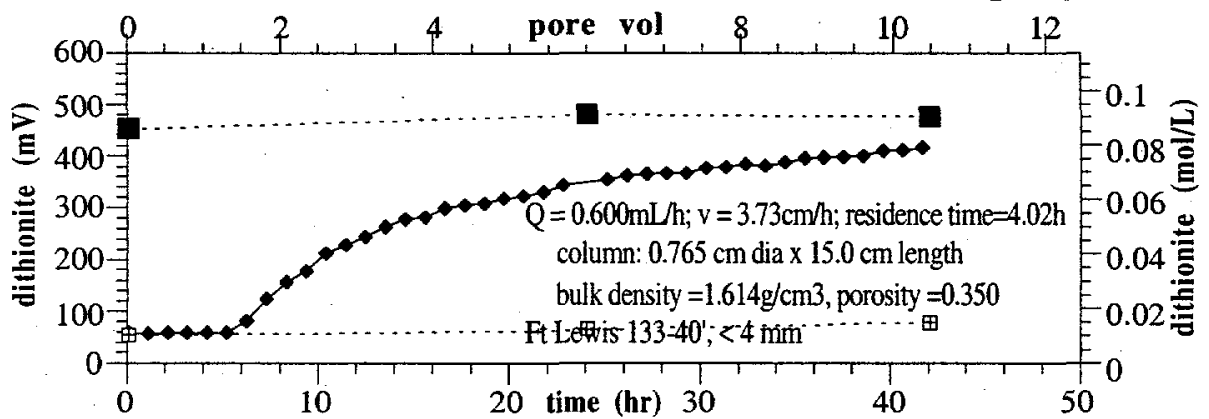

B. 1 
Ft Lewis KF8: Dithionite for $0.09 \mathrm{M}$ dith $+0.36 \mathrm{M} \mathrm{K} \mathrm{CO}_{3}$ inject

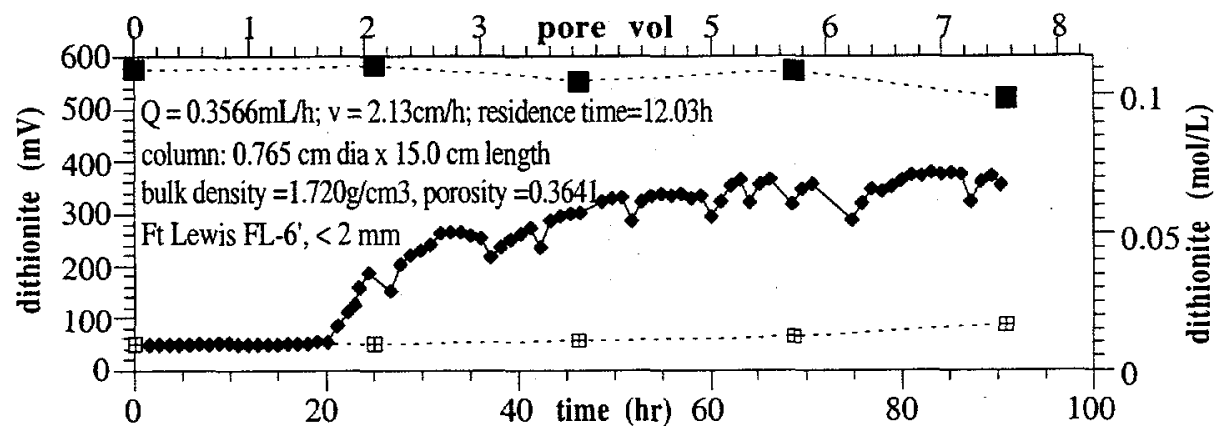

Ft Lewis KF9: Dithionite for $0.09 \mathrm{M}$ dith $+0.36 \mathrm{M} \mathrm{K} \mathrm{CO}_{3}$ inject

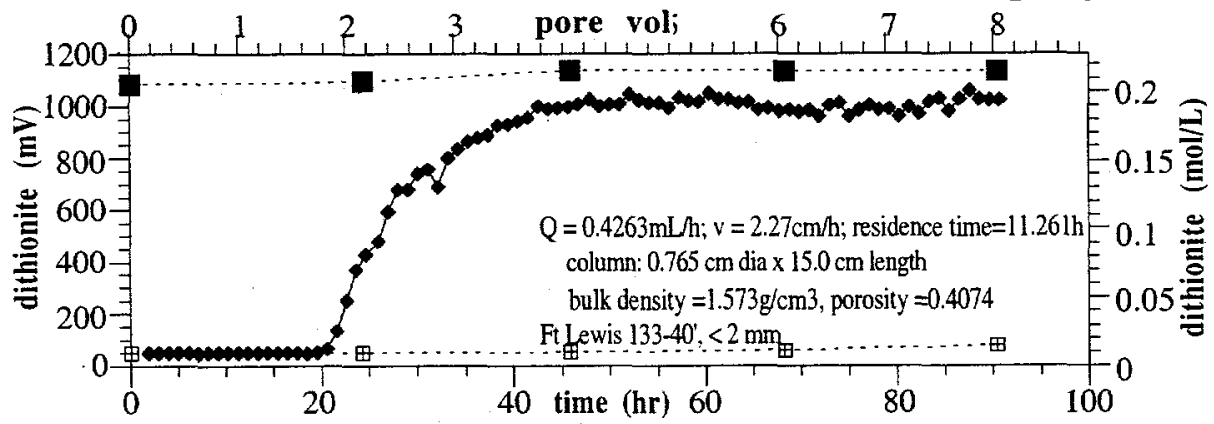

Ft Lewis KF14: Dithionite for $0.09 \mathrm{M}$ dith $+0.36 \mathrm{M} \mathrm{K} \mathrm{KO}_{3}$ inject

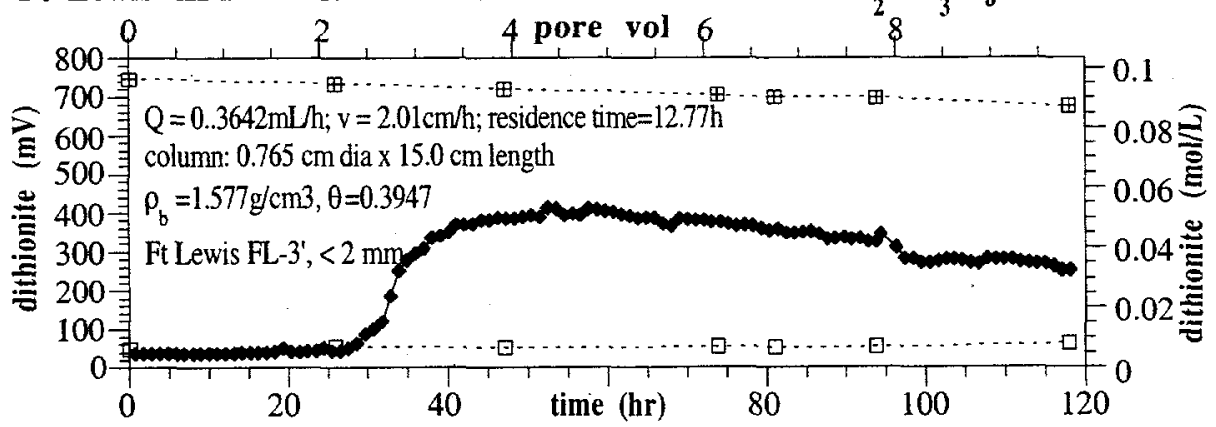

Ft Lewis KF18: Dithionite for $0.09 \mathrm{M}$ dith $+0.36 \mathrm{M} \mathrm{K} \mathrm{CO}_{3}$ inject

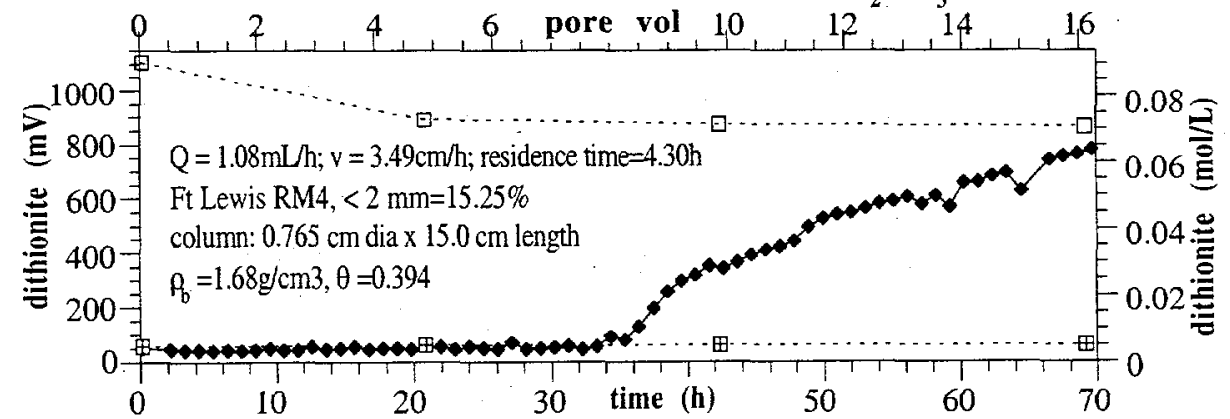

B. 2 
Ft Lewis KF19: Dithionite for $0.09 \mathrm{M}$ dith $+0.36 \mathrm{M} \mathrm{K} \mathrm{CO}_{3}$ inject

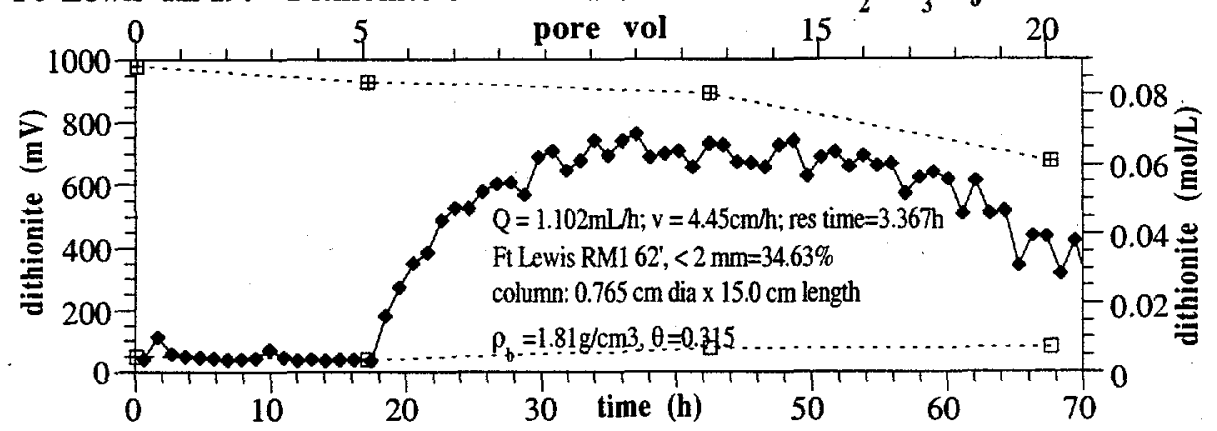

Ft Lewis KF20: Dithionite for $0.09 \mathrm{M}$ dith $+0.36 \mathrm{M} \mathrm{K} \mathrm{CO}_{3}$ inject

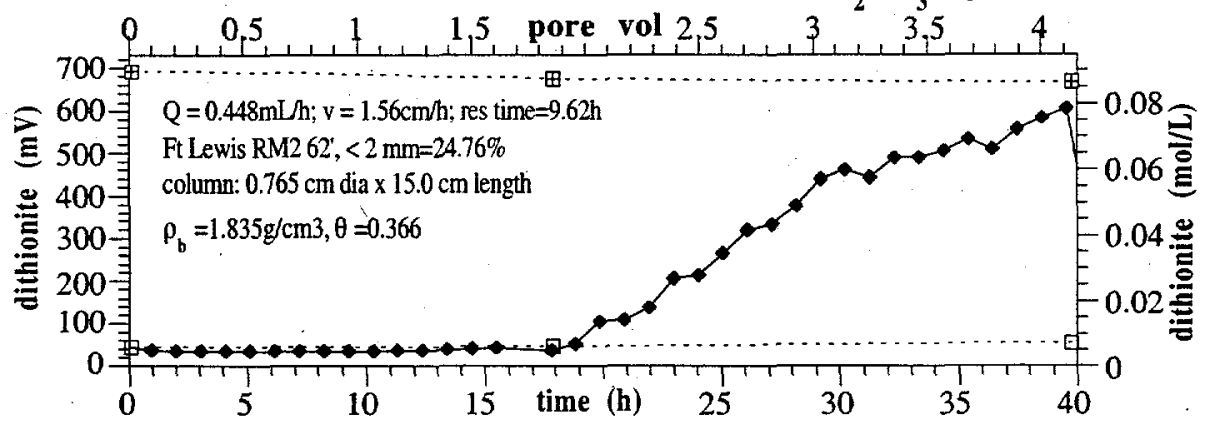

Ft Lewis KF21: Dithionite for $0.06 \mathrm{M}$ dith $+0.24 \mathrm{M} \mathrm{K} \mathrm{CO}_{3}$ inject

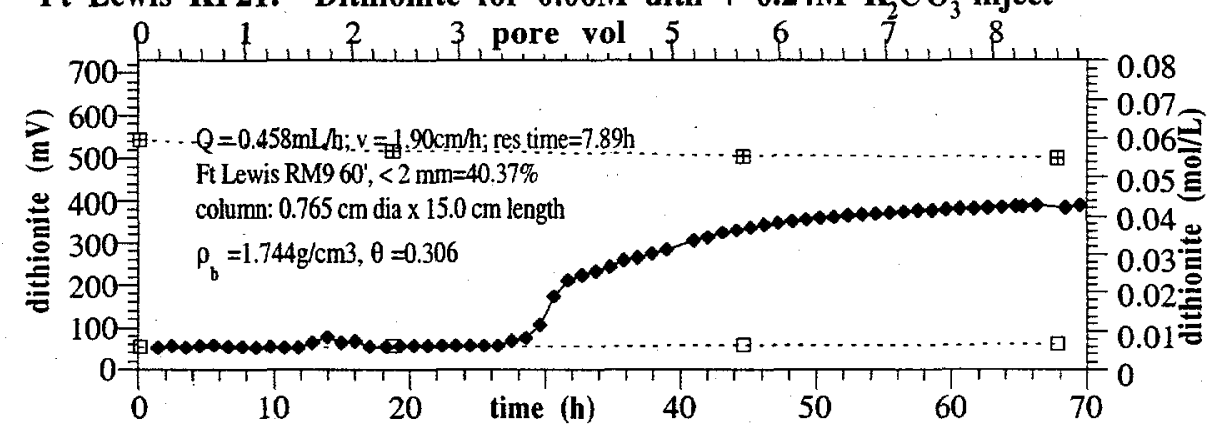

Ft Lewis KF22: Dithionite for $0.03 \mathrm{M}$ dith $+0.12 \mathrm{M} \mathrm{K} \mathrm{CO}_{3}$ inject

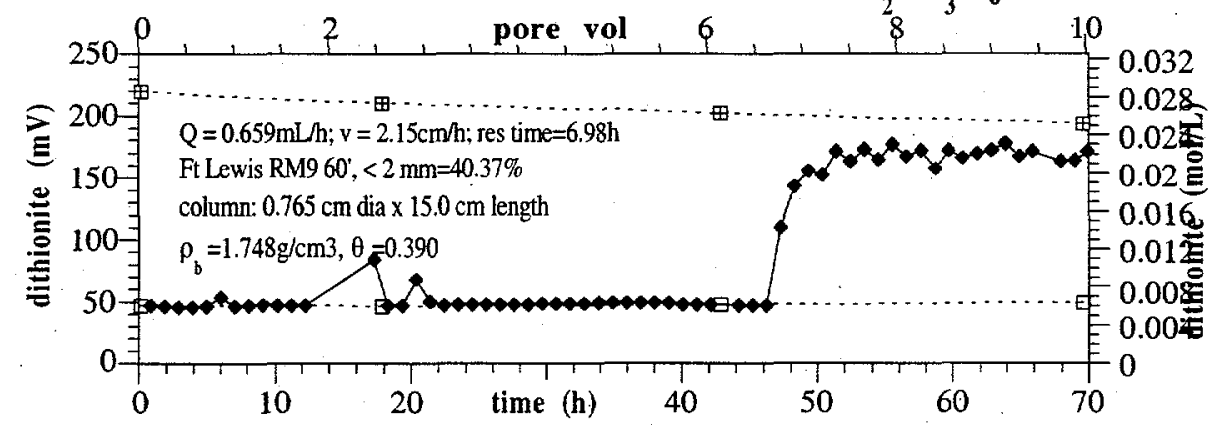

B. 3 
KF49: Dithionite for $0.09 \mathrm{M}$ dith $+0.36 \mathrm{M} \mathrm{K} \mathrm{CO}_{3}$ inject

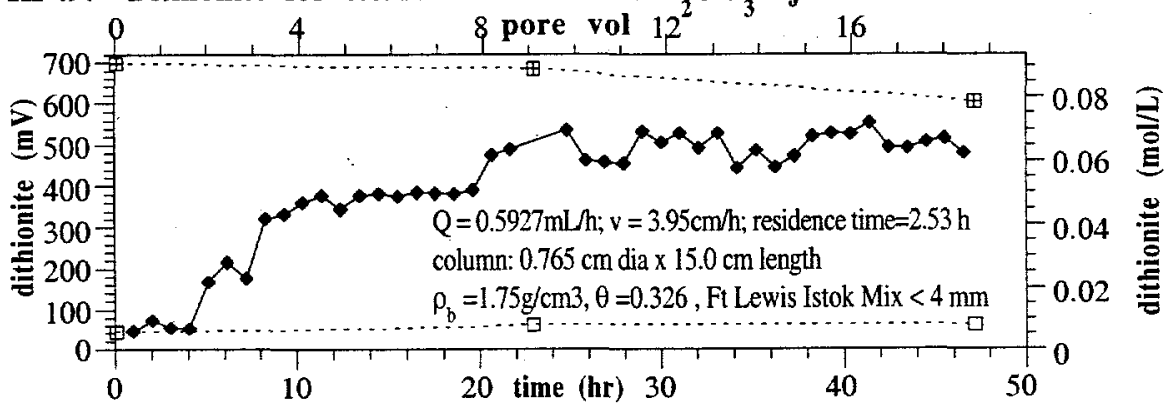

KF49: $\mathrm{pH}$ for $0.09 \mathrm{M}$ dith $+0 . .36 \mathrm{M} \mathrm{K}, \mathrm{CO}_{3}$ inject

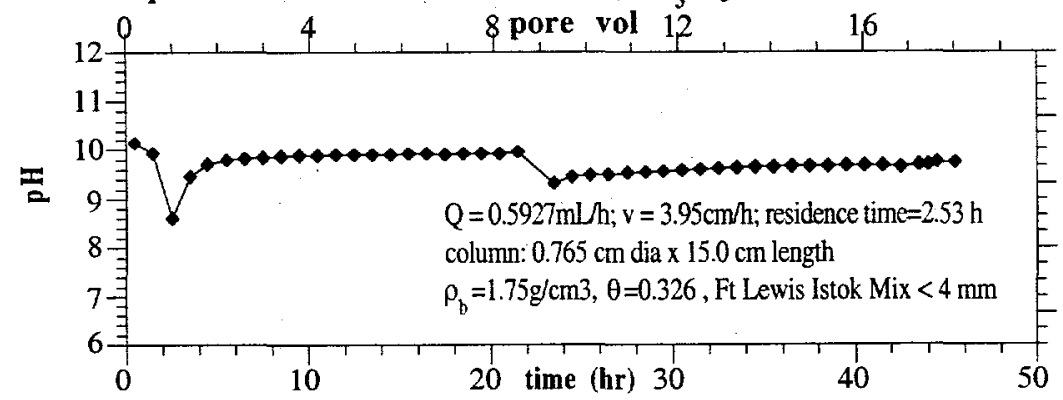

KF50: Dithionite for $0.09 \mathrm{M}$ dith $+0.27 \mathrm{M} \mathrm{K}_{2} \mathrm{CO}_{3}$ inject

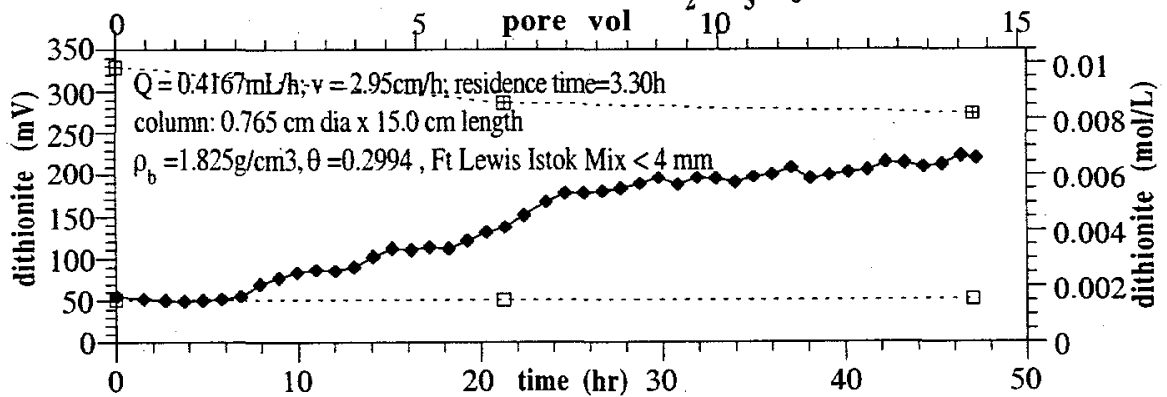

KF50: $\mathrm{pH}$ for $0.09 \mathrm{M}$ dith $+0.27 \mathrm{M} \mathrm{K} \mathrm{CO}_{3}$ inject

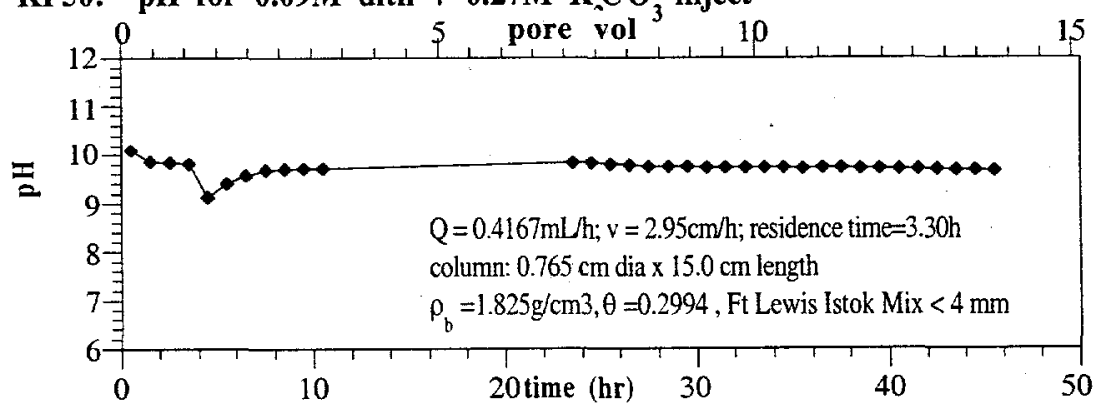


KF53: Dithionite for $0.09 \mathrm{M}$ dith $+0.27 \mathrm{M} \mathrm{K} \mathrm{CO}_{3}$ inject

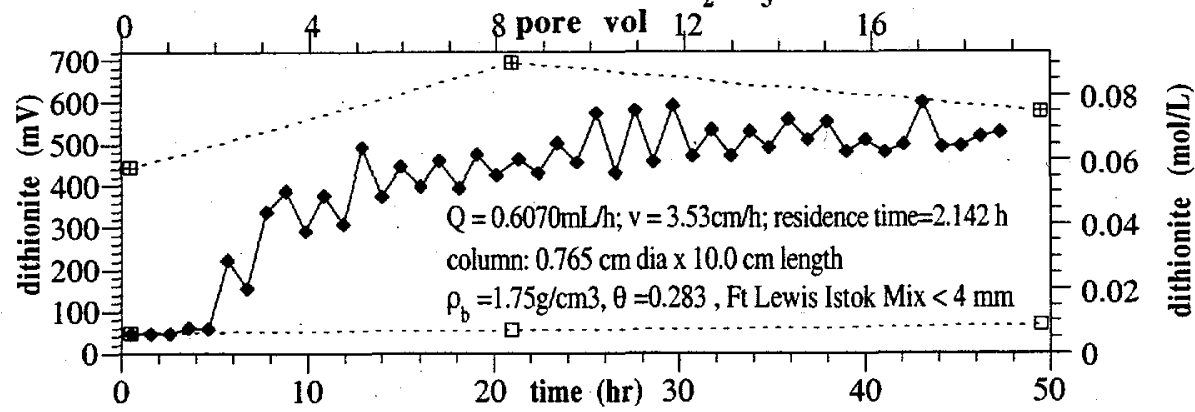

KF53: $\mathrm{pH}$ for $0.09 \mathrm{M}$ dith $+0.27 \mathrm{M} \mathrm{K} \mathrm{CO}_{3}$ inject

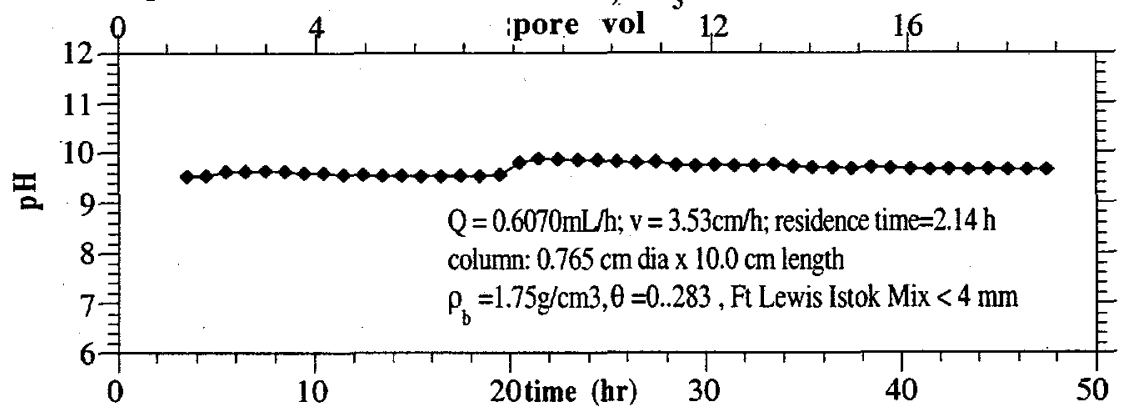

KF54: Dithionite for $0.09 \mathrm{M}$ dith $+0.18 \mathrm{M} \mathrm{K} \mathrm{CO}_{3}$ inject

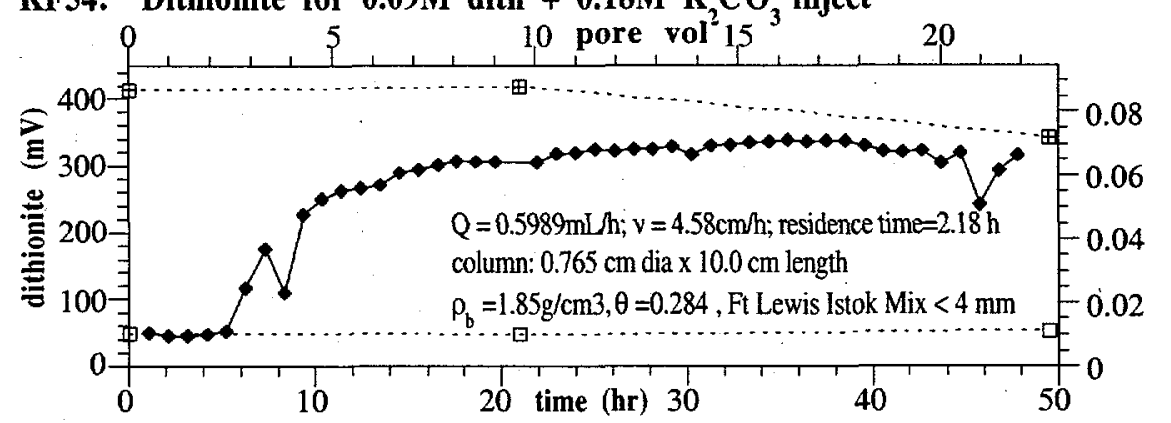

KF54: $\mathrm{pH}$ for $0.09 \mathrm{M}$ dith $+0.18 \mathrm{M} \mathrm{K}_{2} \mathrm{CO}_{3}$ inject

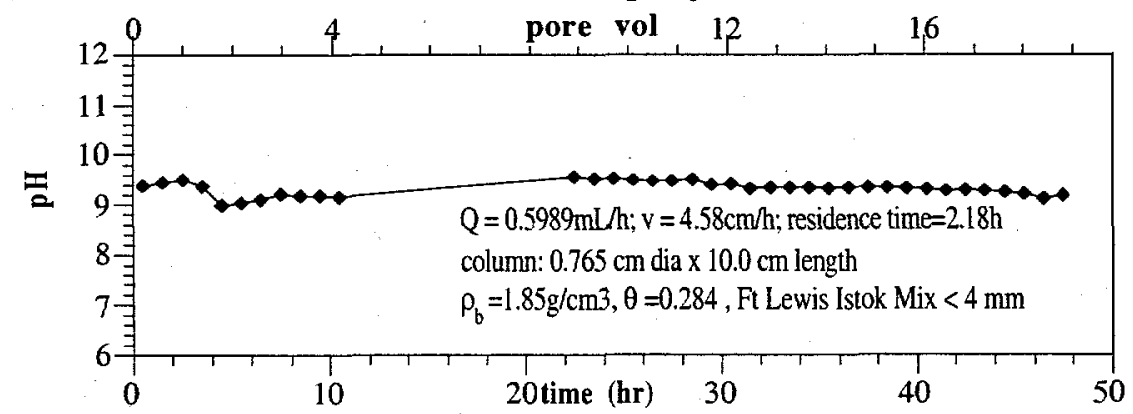


KF57: Dithionite for $0.09 \mathrm{M}$ dith $+0.18 \mathrm{M} \mathrm{K} \mathrm{CO}_{3}$ inject

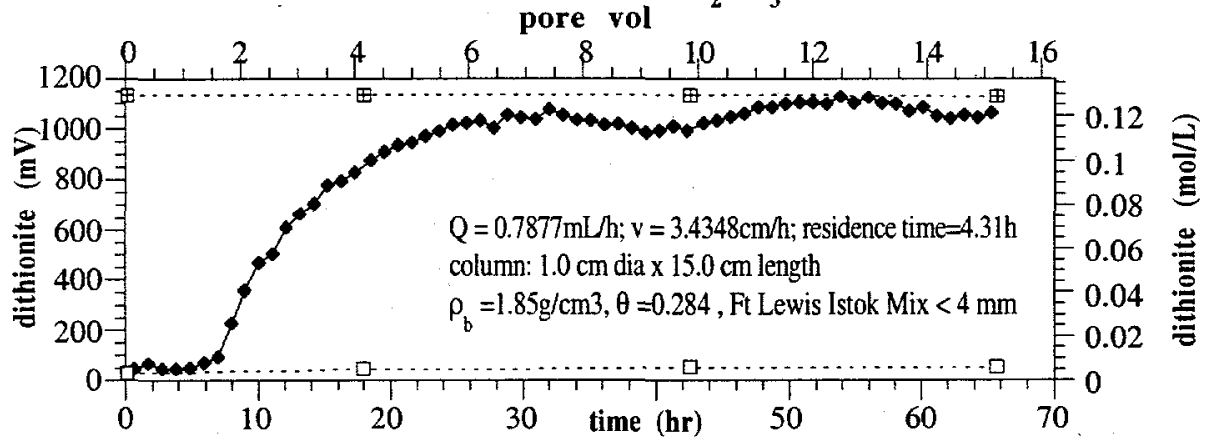

KF57: $\mathrm{pH}$ for $0.09 \mathrm{M}$ dith $+0.18 \mathrm{M} \mathrm{K} \mathrm{CO}_{3}$ inject

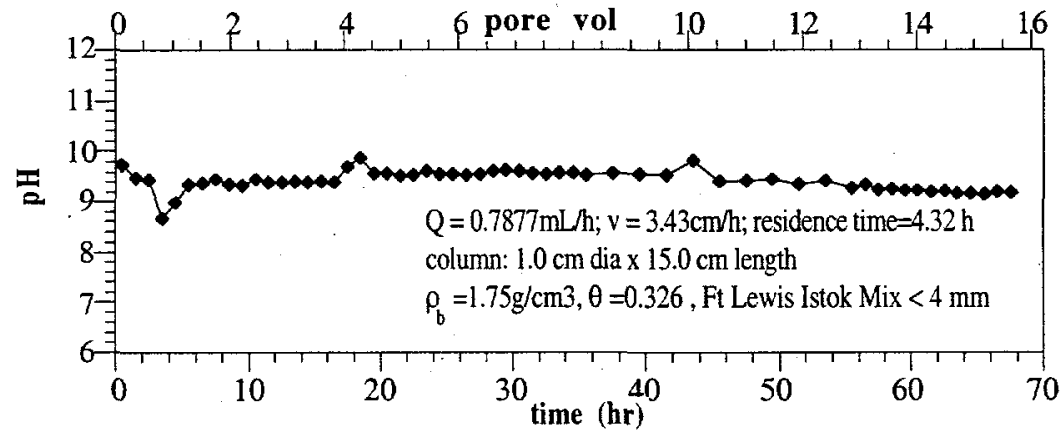

KF61: Dithionite for $0.09 \mathrm{M}$ dith $+0.045 \mathrm{M} \mathrm{K} \mathrm{CO}_{3}$ inject

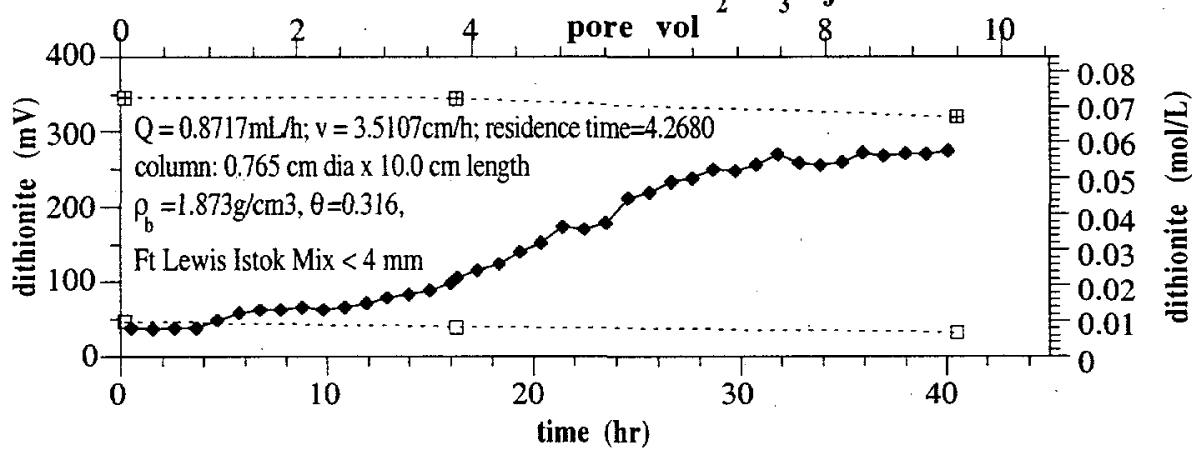

KF61: $\mathrm{pH}$ for $0.09 \mathrm{M}$ dith $+0.045 \mathrm{M} \mathrm{K} \mathrm{CO}_{3}$ inject

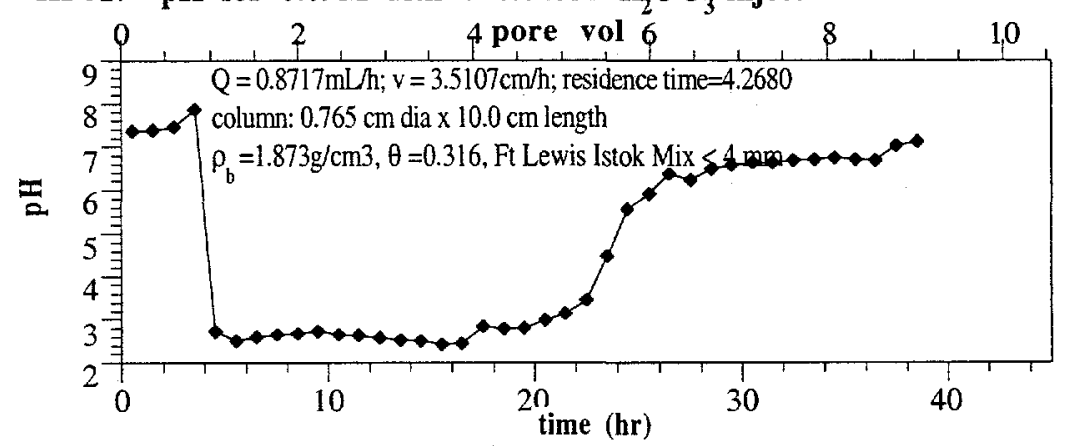

B. 6 
KF58: Dithionite for $0.09 \mathrm{M}$ dith $+0.09 \mathrm{M} \mathrm{K} \mathrm{CO}_{3}$ inject

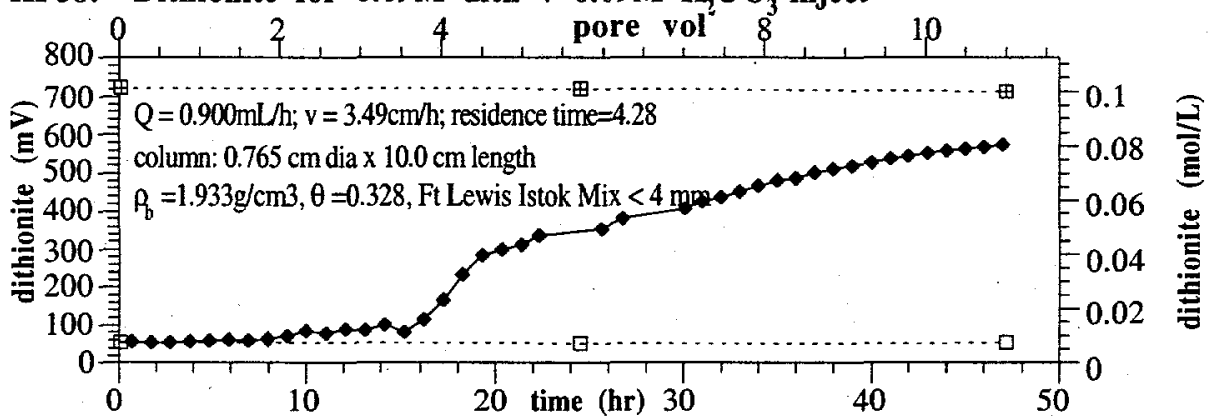

KF58: $\mathrm{pH}$ for $0.09 \mathrm{M}$ dith $+0.09 \mathrm{M} \mathrm{K} \mathrm{CO}_{3}$ inject-two separate experiments

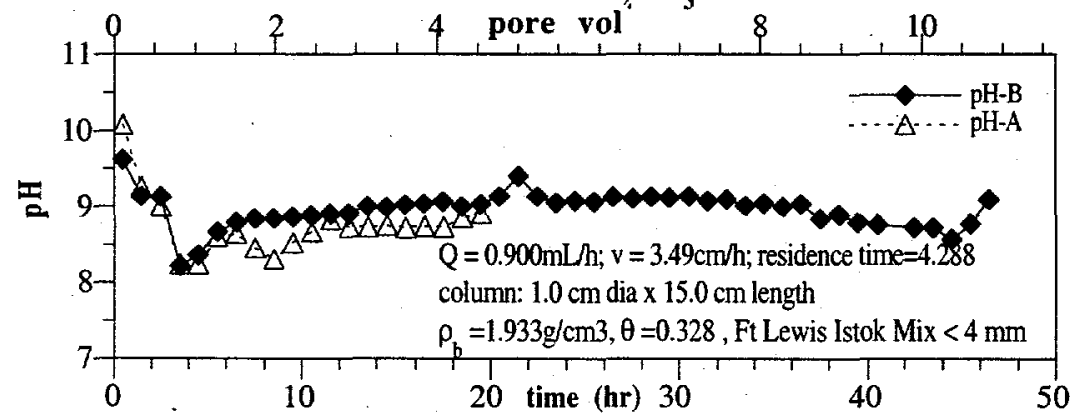

KF58: Total Fe for $0.09 \mathrm{Mdith}+0.09 \mathrm{MK}_{2} \mathrm{CO}_{3}$ inject

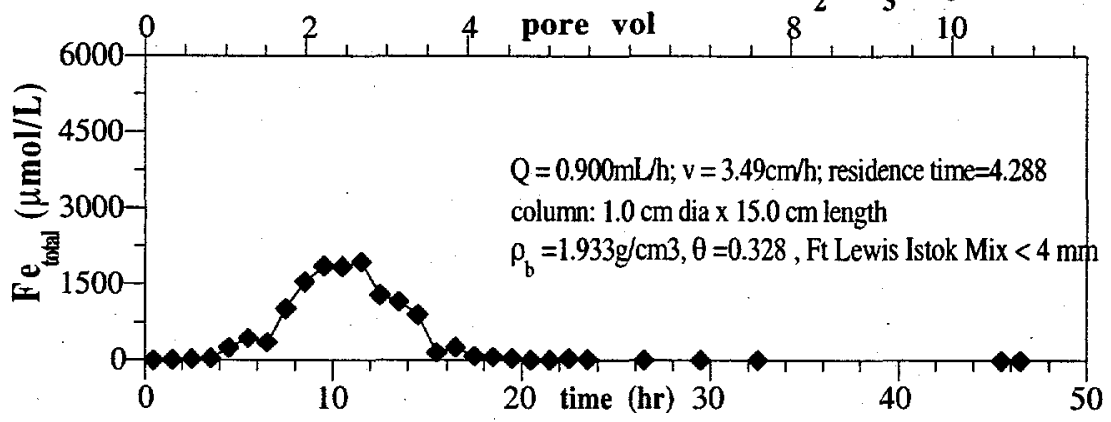

B.7 
KF59: Dithionite for $0.09 \mathrm{M}$ dith $+0.045 \mathrm{M} \mathrm{K}_{2} \mathrm{CO}_{3}$ inject

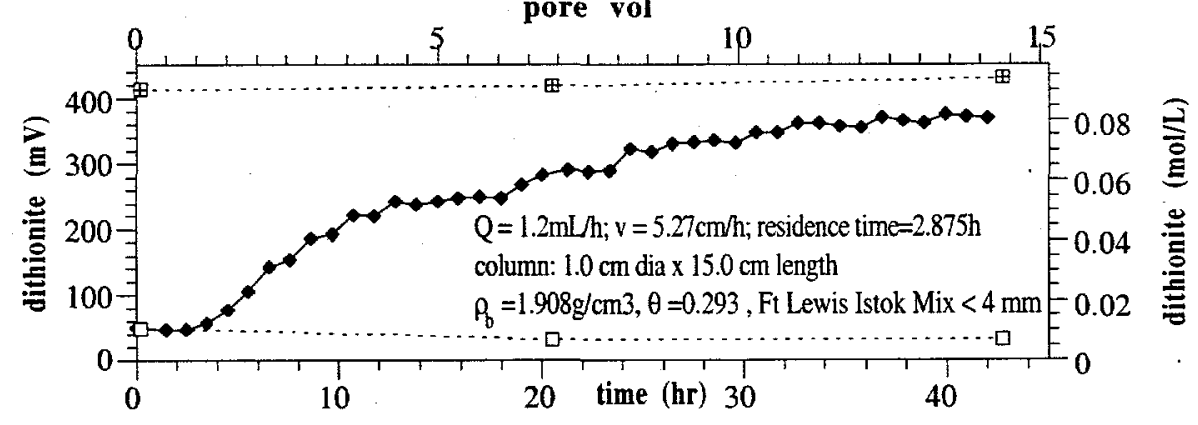

KF59: $\mathrm{pH}$ for $0.09 \mathrm{M}$ dith $+0.045 \mathrm{M} \mathrm{K}_{2} \mathrm{CO}_{3}$ inject

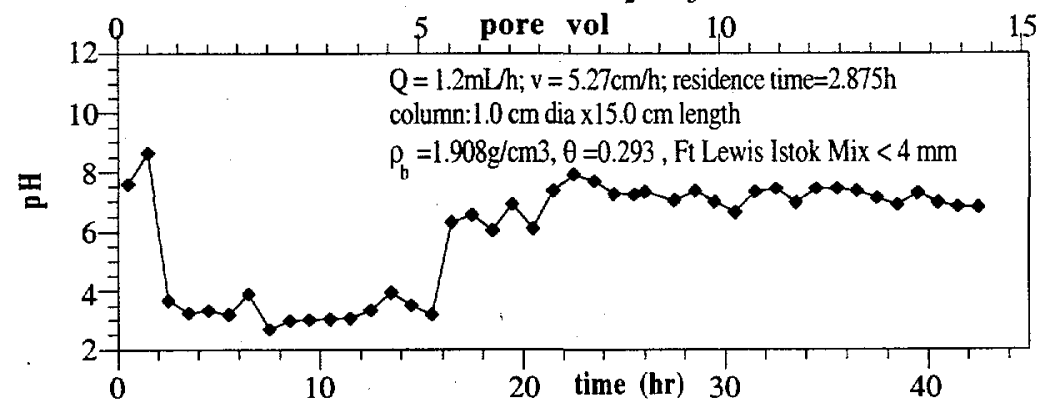

KF59: Total Fe 0.09M dith $+0.045 \mathrm{M} \mathrm{K}_{2} \mathrm{CO}_{3}$ inject

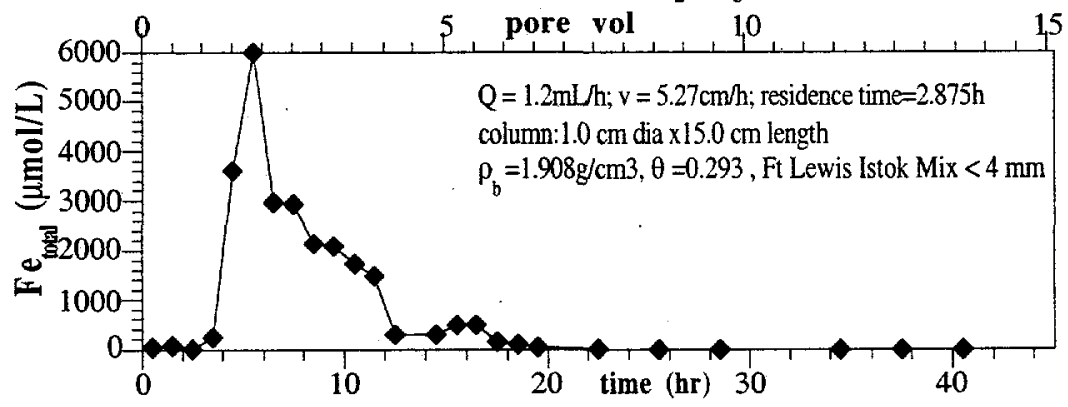

B. 8 


\section{Appendix C}

Column Oxidation Experiments 


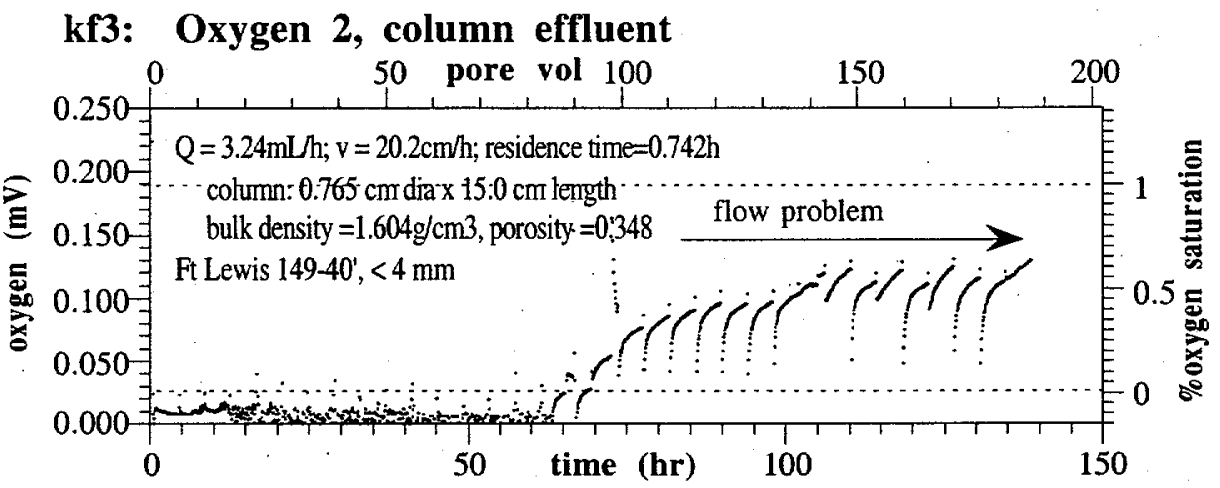

KF4: Disolved Oxygen of Column Effluent (probe \#2)

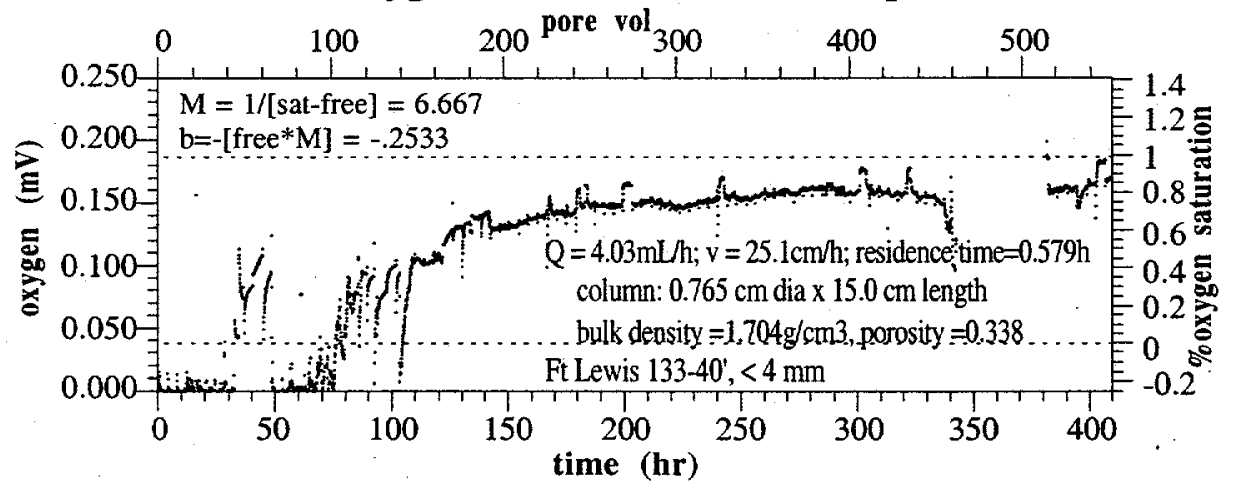

\section{Kf7: Oxygen 2, colump effluent}

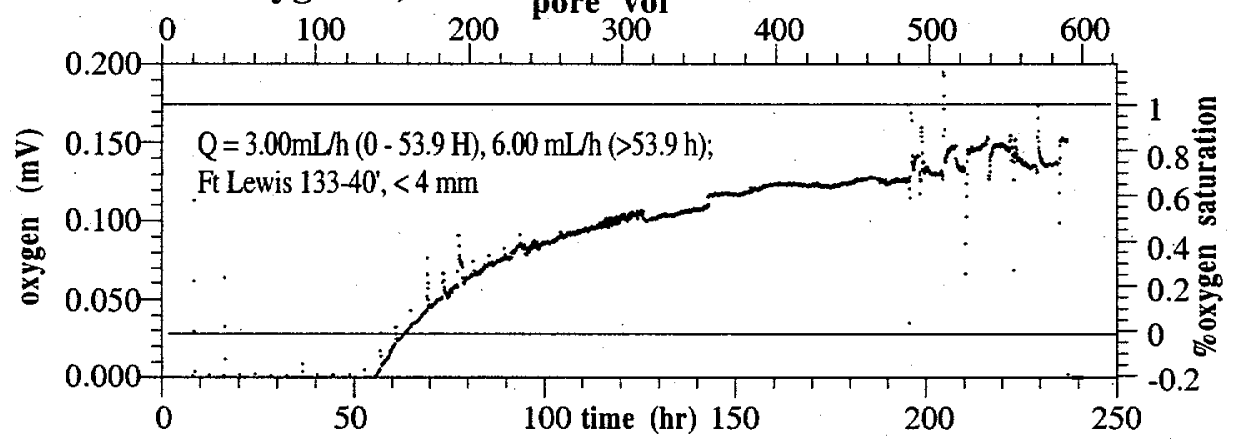

KF10: Column Effluent - Dissolved Oxygen, Probe 1

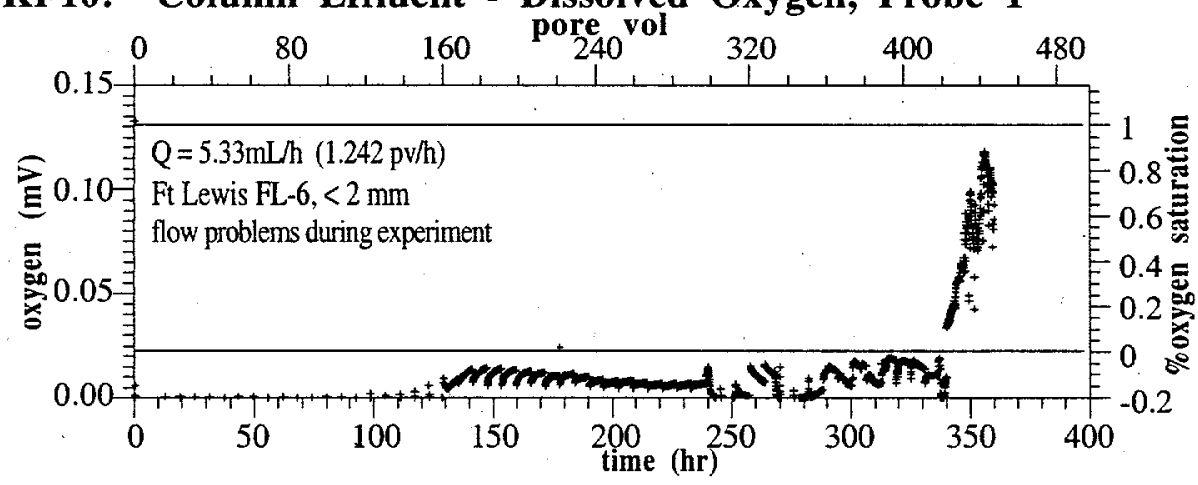

C. 1 
KF11: Column Effluent - Dissolved Oxygen, Probe 2

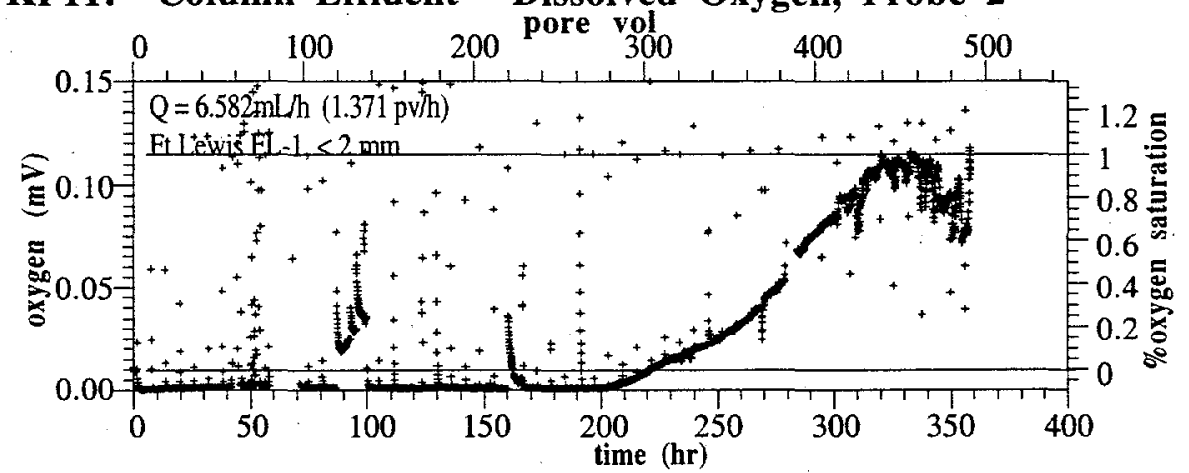

KF16: Dissolved Oxygen in Effluent, Probe 2

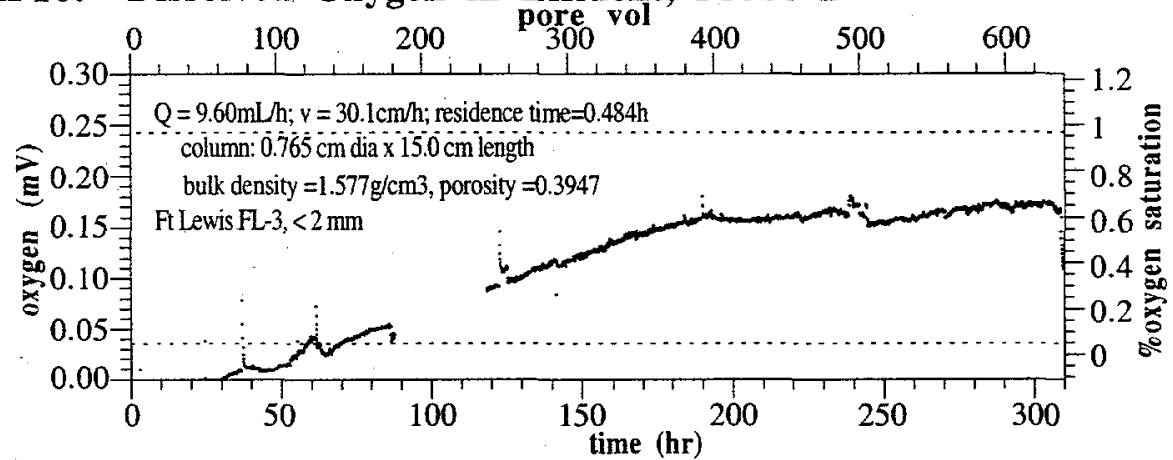

KF16: Dissolved Oxygen Stds, Probe 2

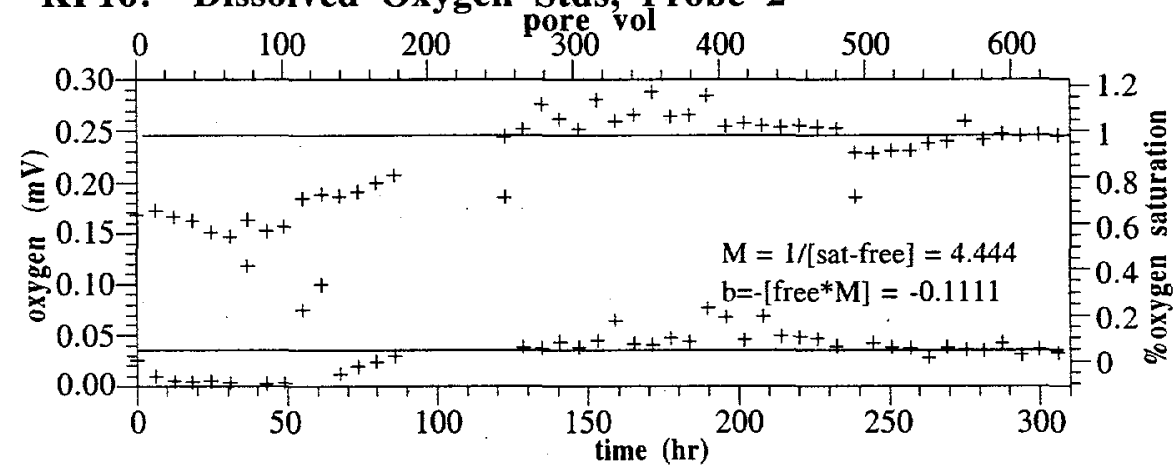


KF43: Dissolved Oxygen from Column, Probe 1

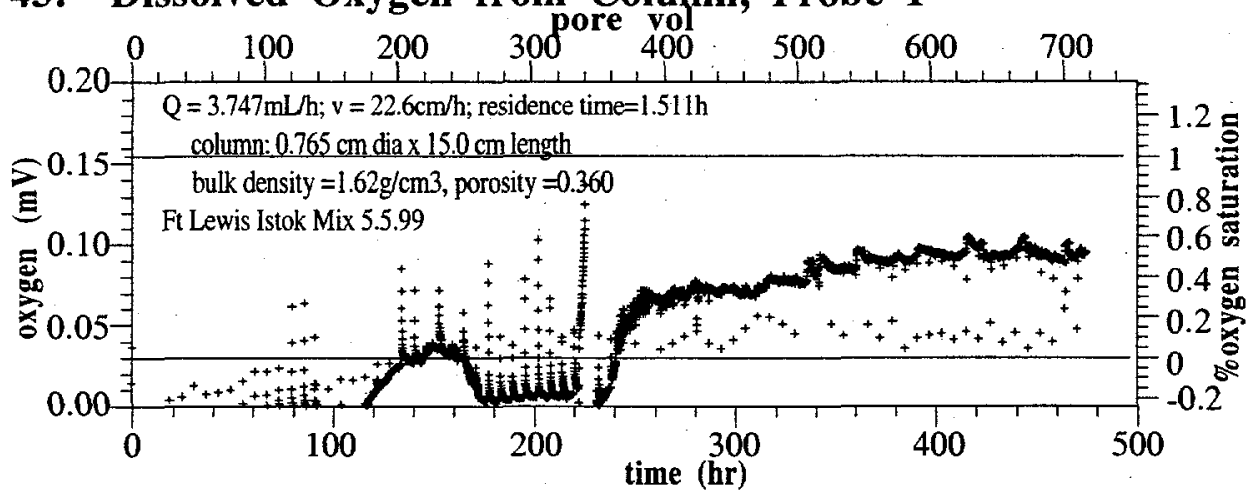

KF45: Dissolved Oxygen Column, Probe 2

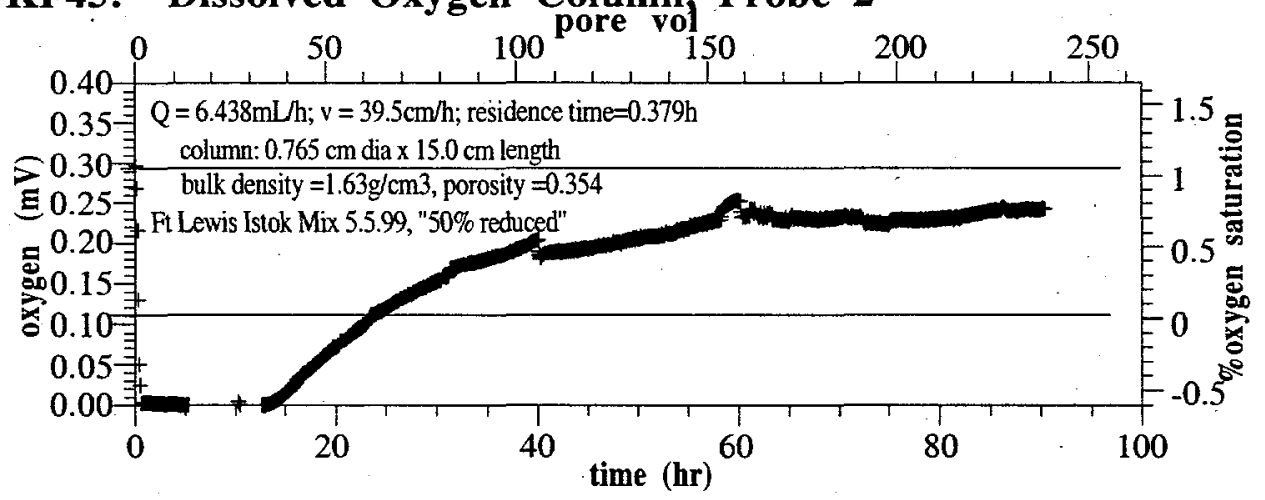

KF47: Dissolved Oxygen in Column, Probe 1

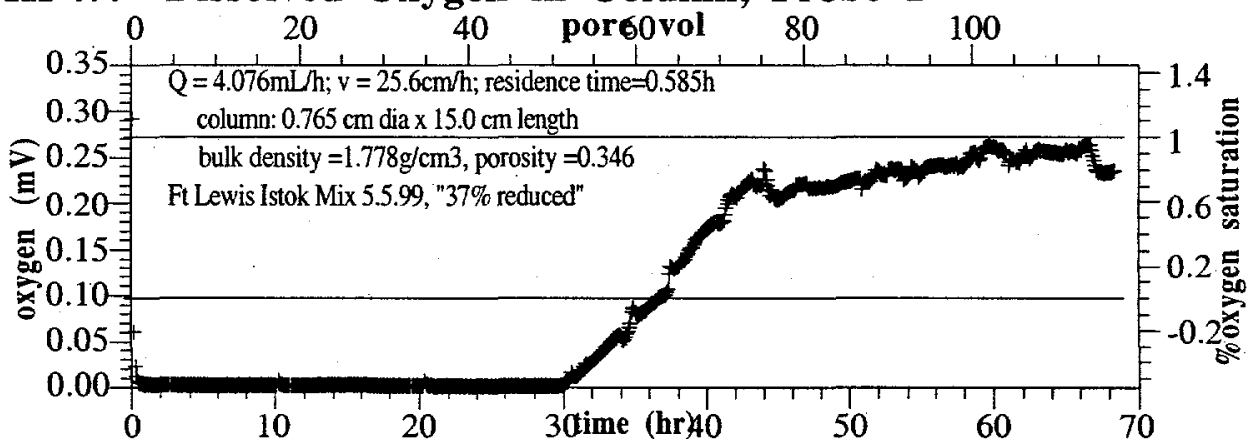

KF48: Dissolved Oxygen Effluent, Probe 1

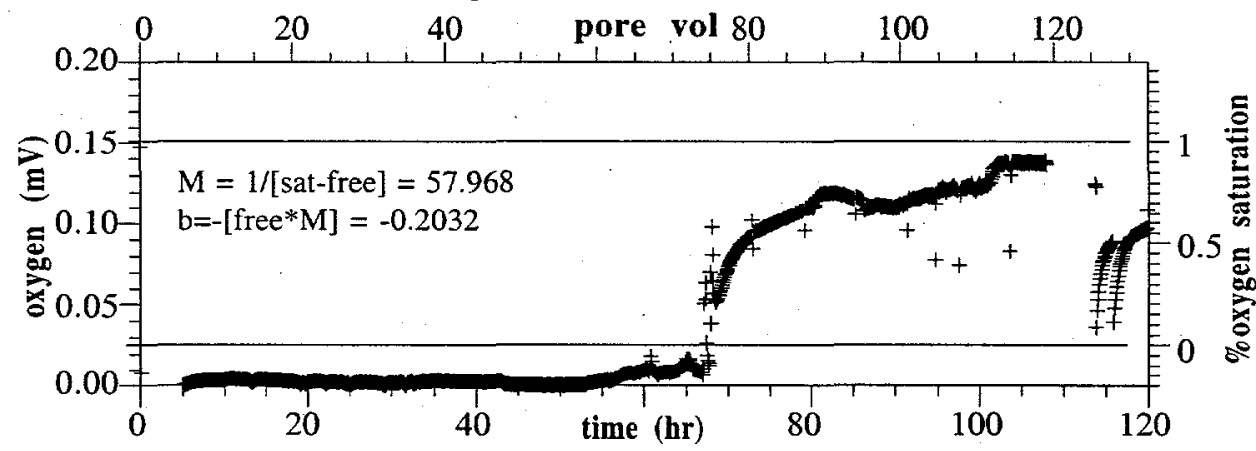


KF51: Dissolved Oxygen Column Effluent, Probe 2

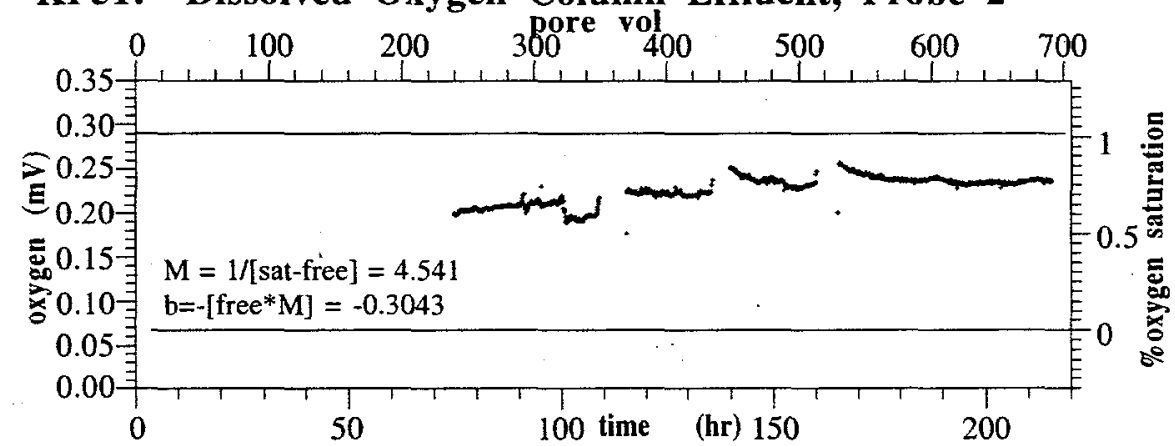

KF52: Dissolved Oxygen Column Effluent, Probe 2

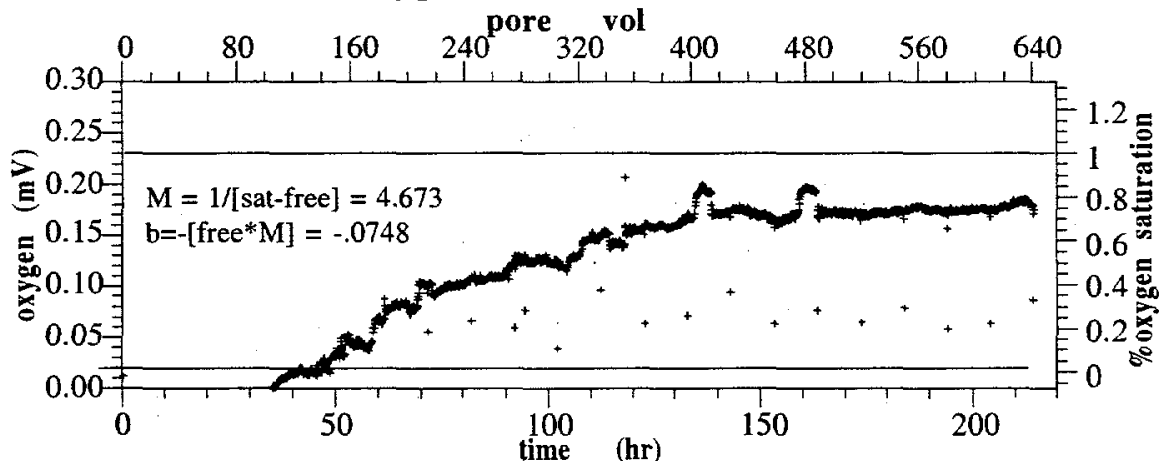

KF55: Dissolved Oxygen Column Effluent, Probe 1

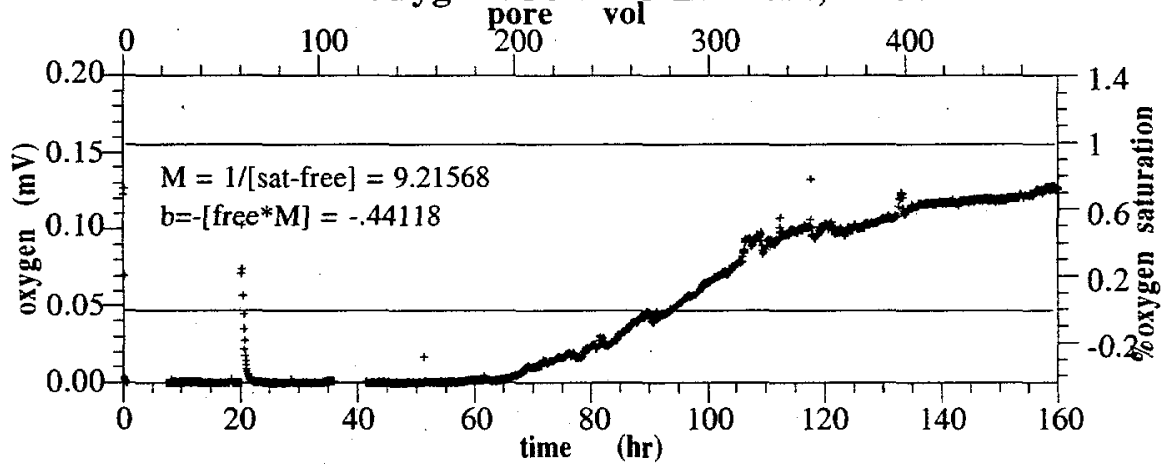


KF56: Dissolved Oxygen Column Effluent, Probe 2

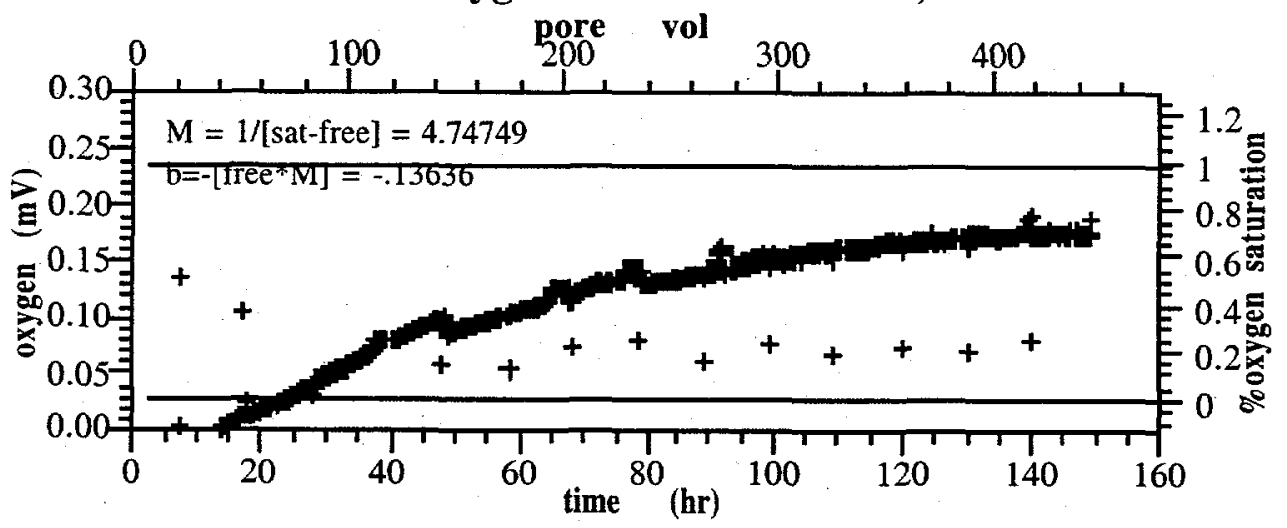

KF60: Dissolved Oxygen Effluent, Probe 1

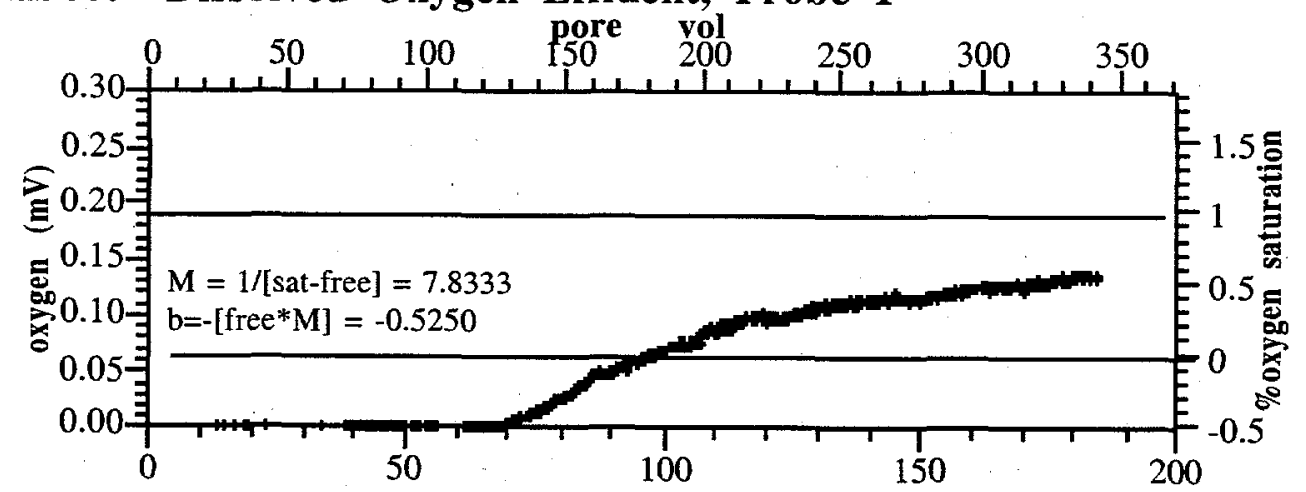


Appendix D

\section{Batch TCE Experiments}


KF13: TCE degradation by Dithionite-Reduced Sediment

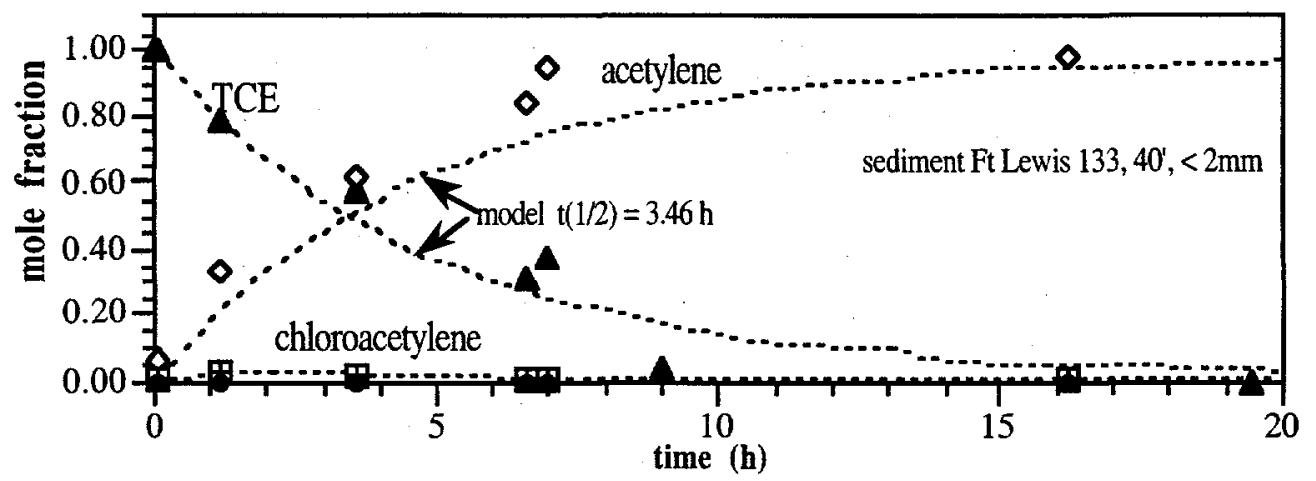

TCE degradation by dithionite-reduced sediment

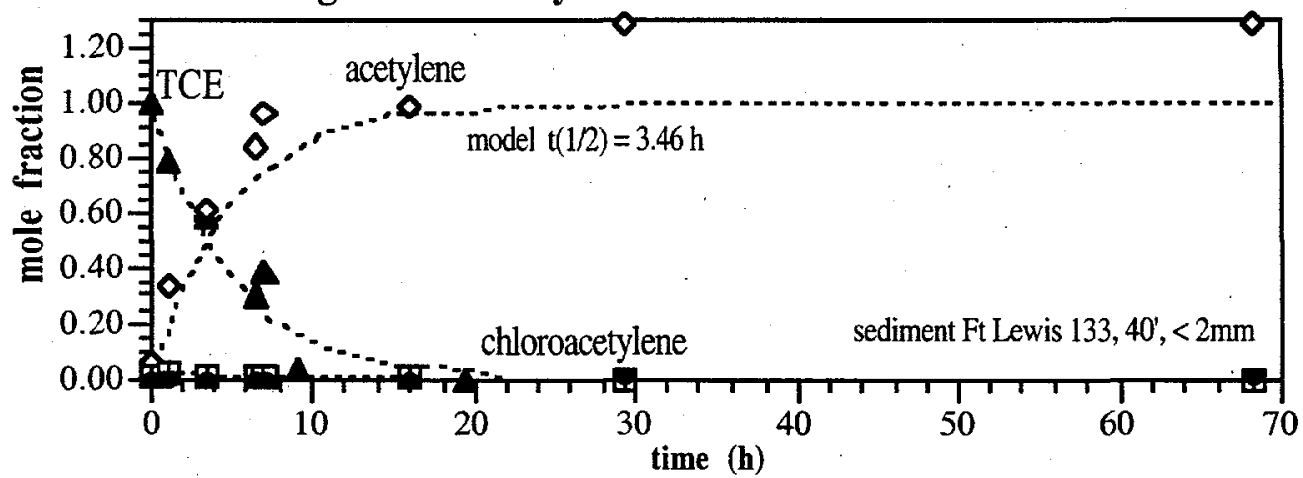

KF13: DCE Nonreactive in Reduced Sediment

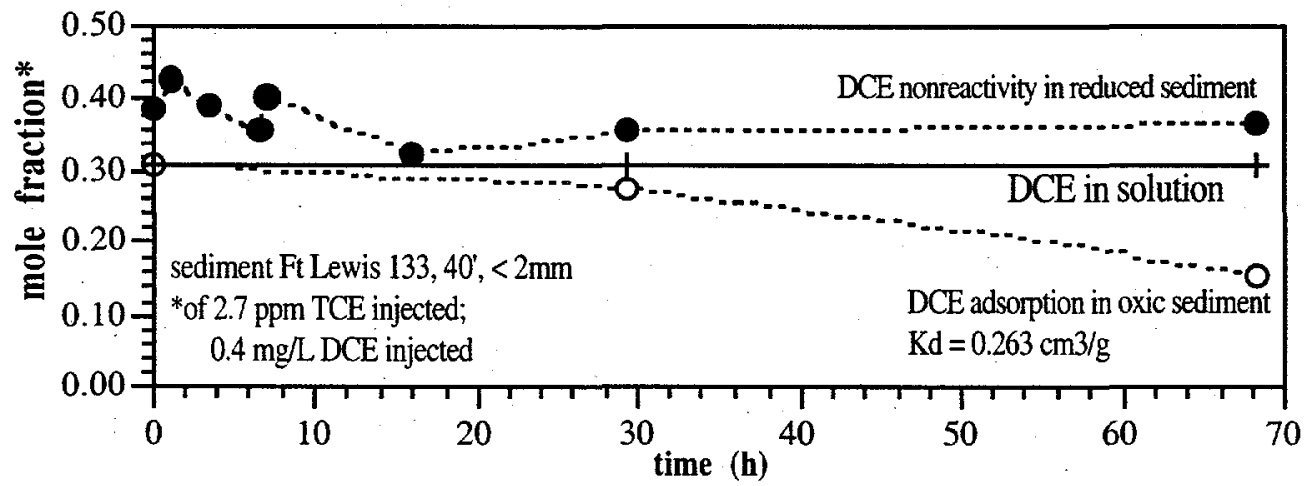

KF13: Vinyl Chloride not Generated, Trace Levels in Groundwater Removed in Reduced Sediment

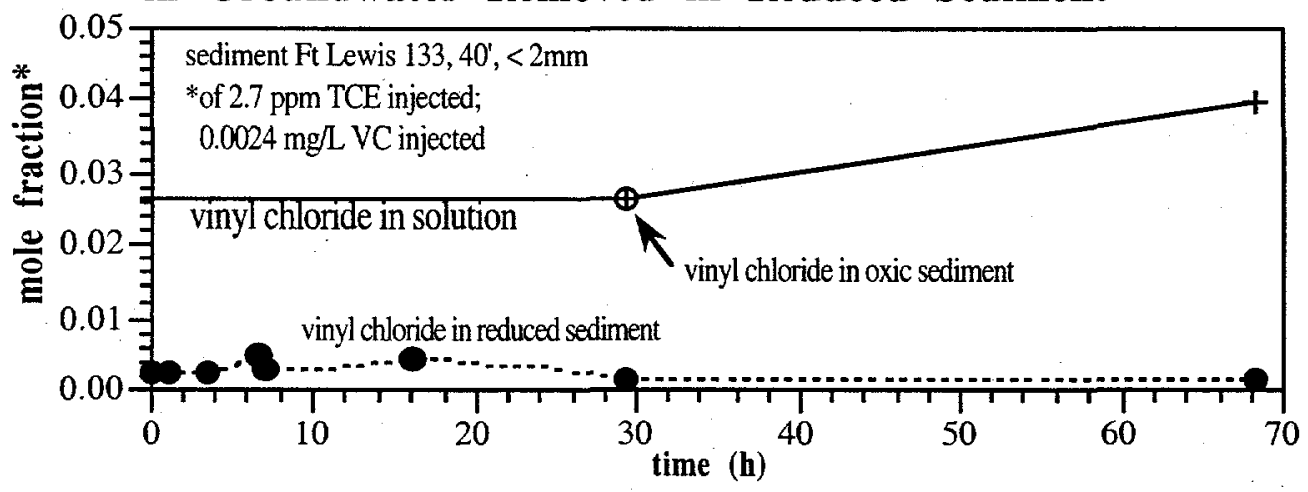

D. 1 
KF24: Batch TCE degradation at $25^{\circ} \mathrm{C}$

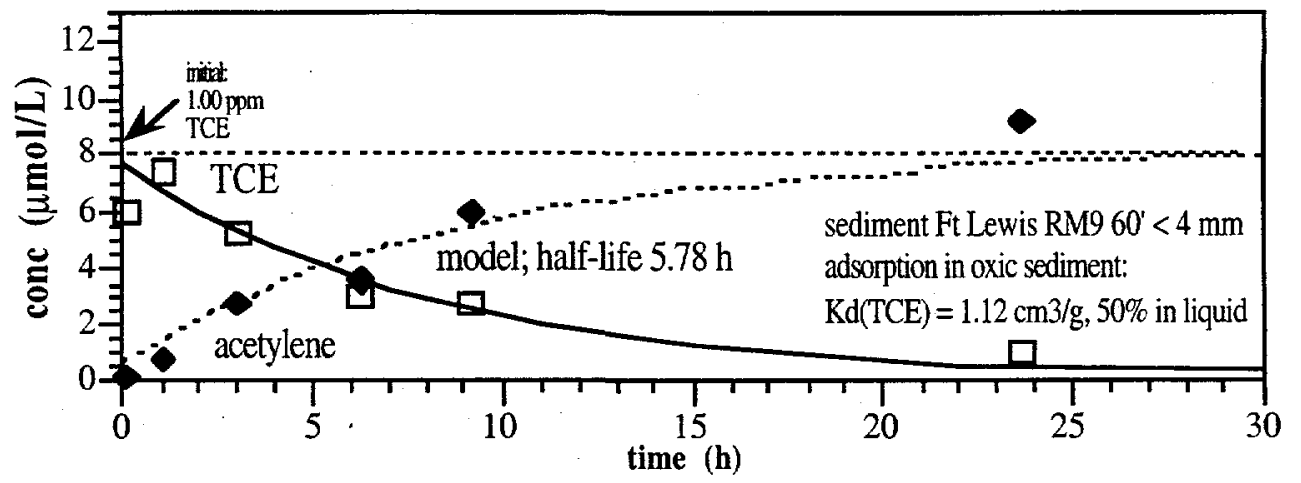

KF25: Batch TCE degradation at $17^{\circ} \mathrm{C}$

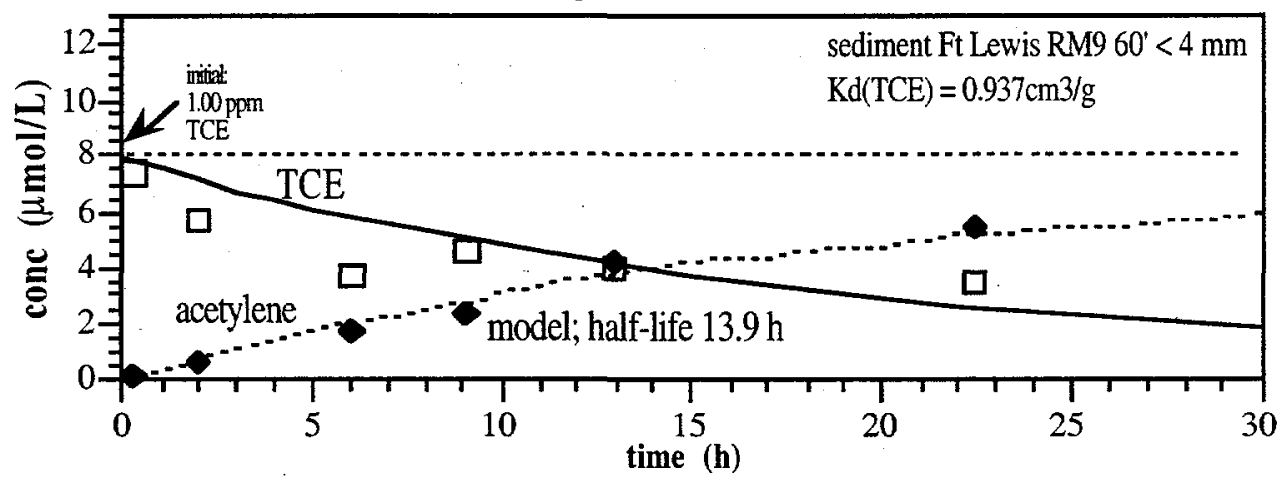

Batch TCE degradation at $10^{\circ} \mathrm{C}$

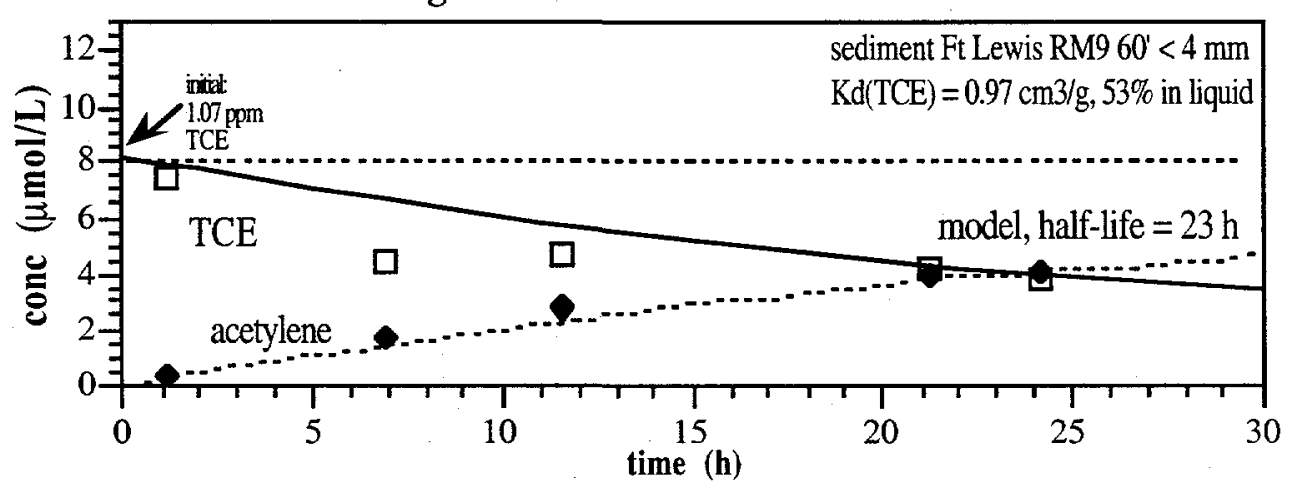

Batch TCE degradation at $10^{\circ} \mathrm{C}$

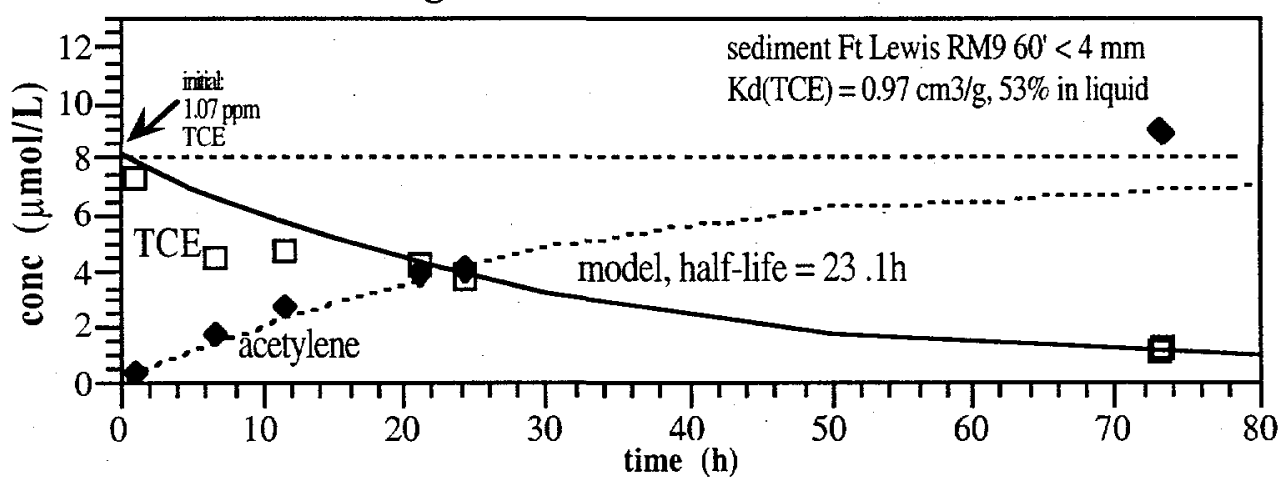

D. 2 
KF33: Batch TCE Degradation at $2^{\circ} \mathrm{C}$

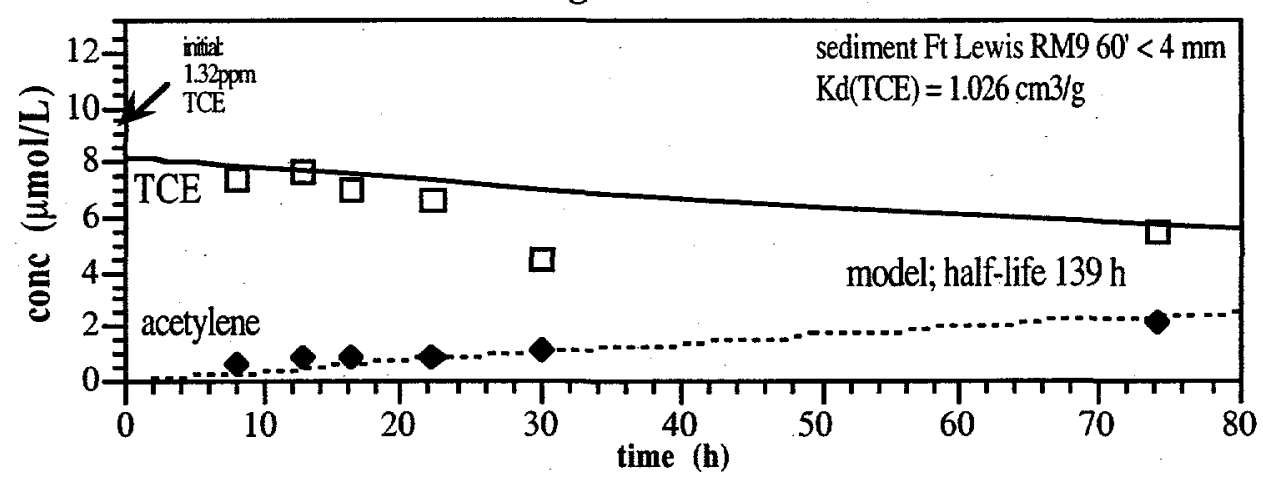

Batch TCE degradation at $42^{\circ} \mathrm{C}$

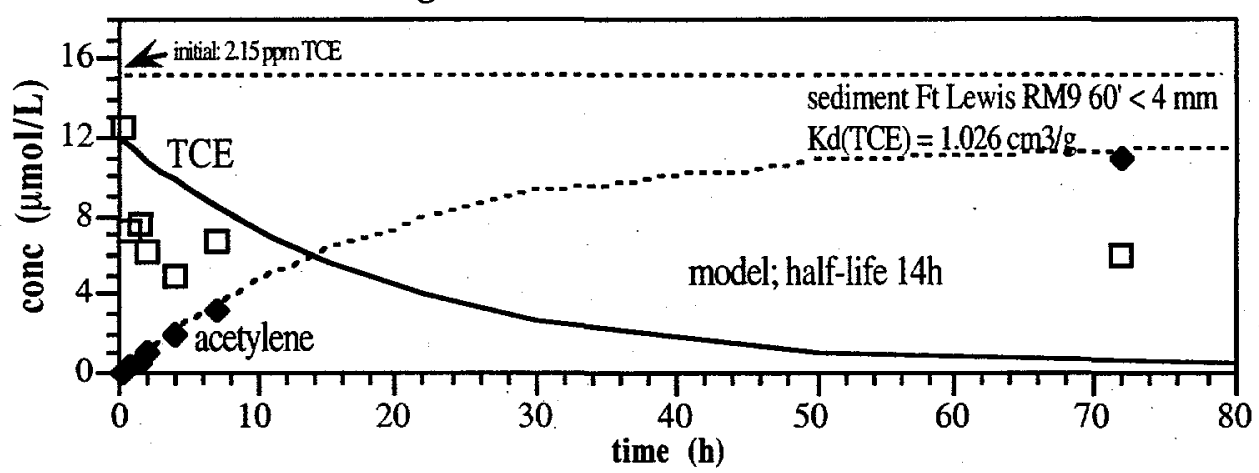

KF40: Sediment Reduction on TCE Degradation Rate

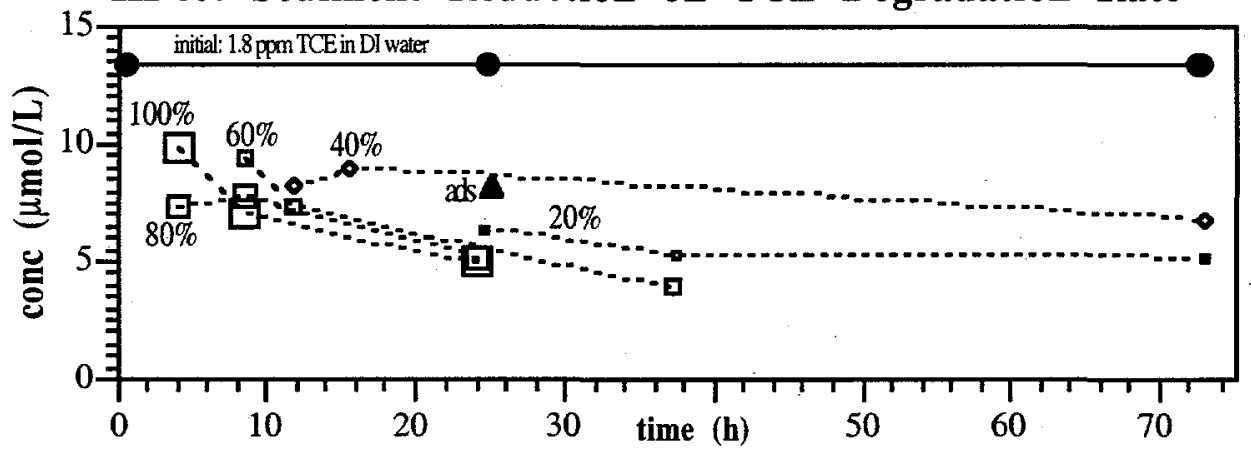

KF40a: $100 \%$ Reduced Sediment, Batch TCE Degradation, $25^{\circ} \mathrm{C}$

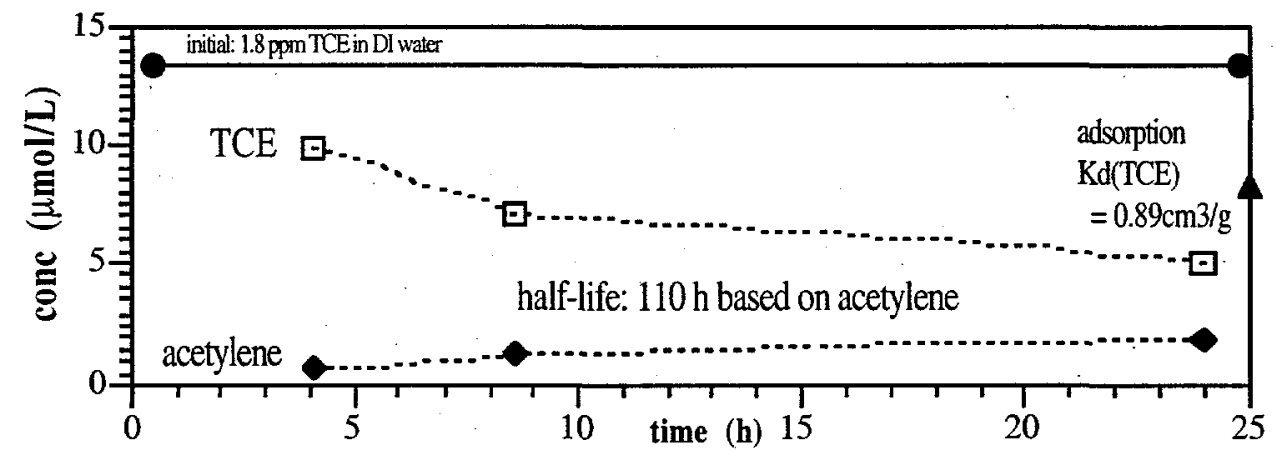

D.3 


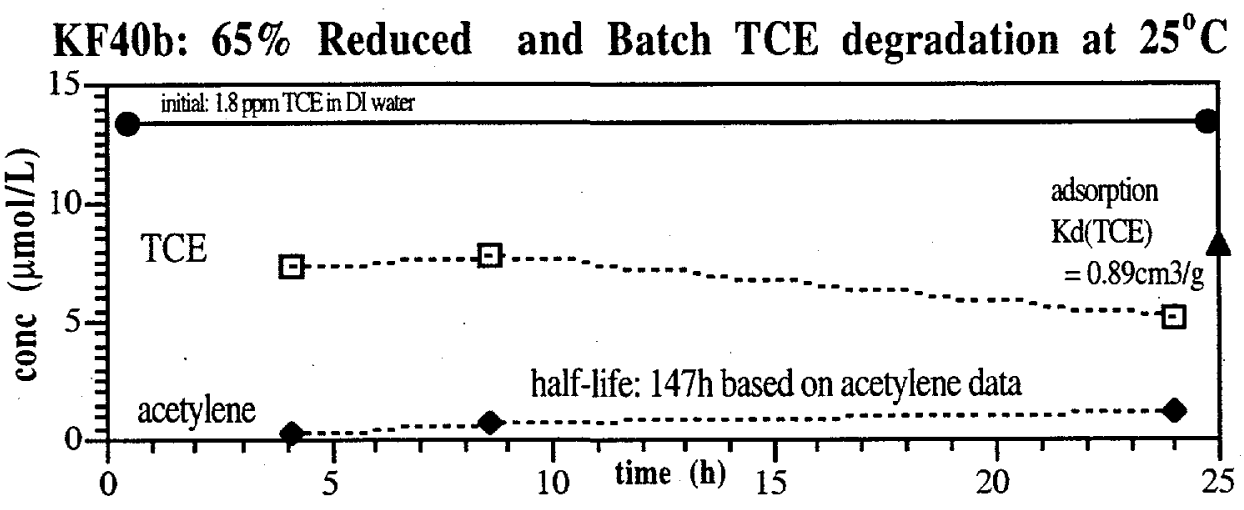

KF40c: $49 \%$. Reduced vs Batch TCE degradation, $25^{\circ} \mathrm{C}$

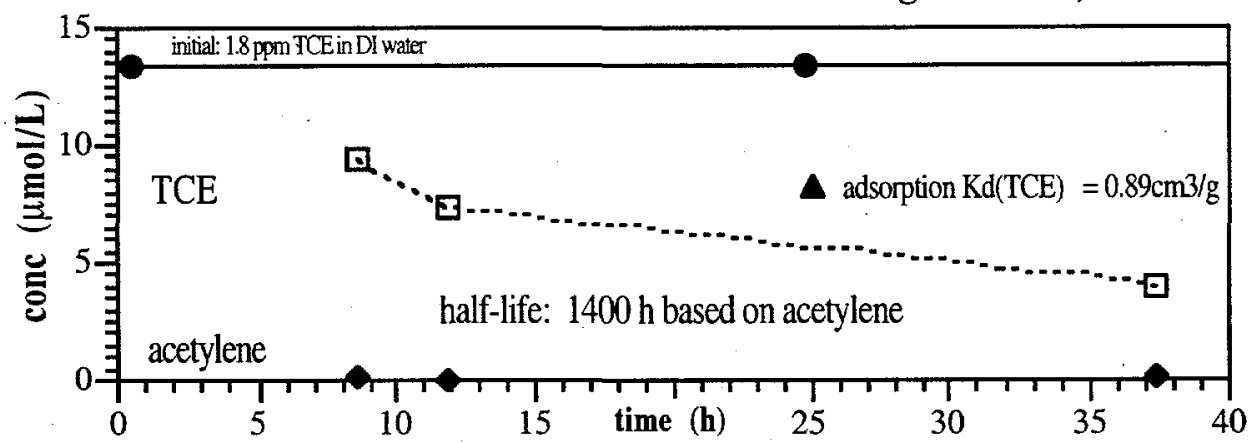

KF40d: 33\% Reduced vs Batch TCE degradation, $25^{\circ} \mathrm{C}$

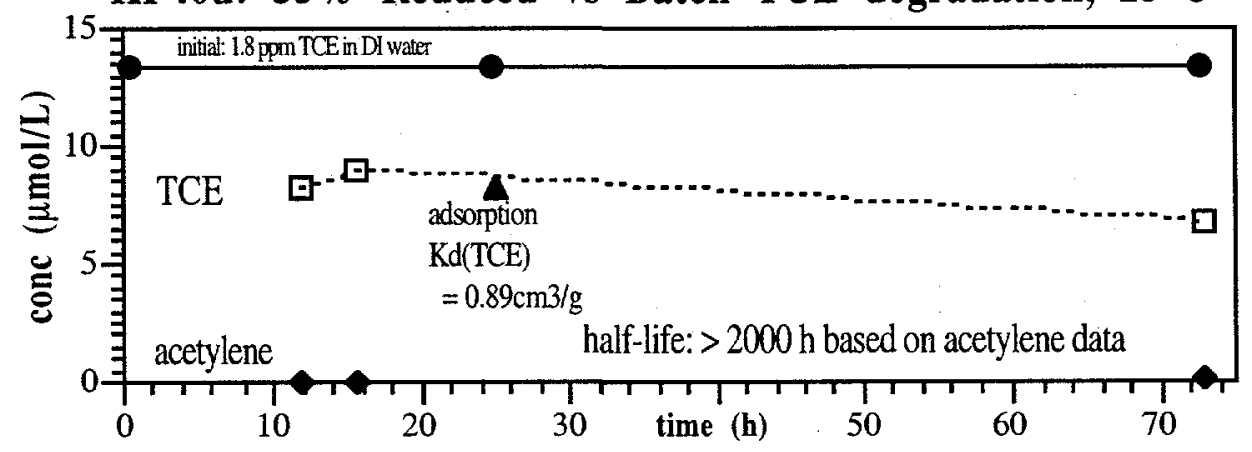

KF40e: $16 \%$ Reduced vs Batch TCE degradation, $25^{\circ} \mathrm{C}$

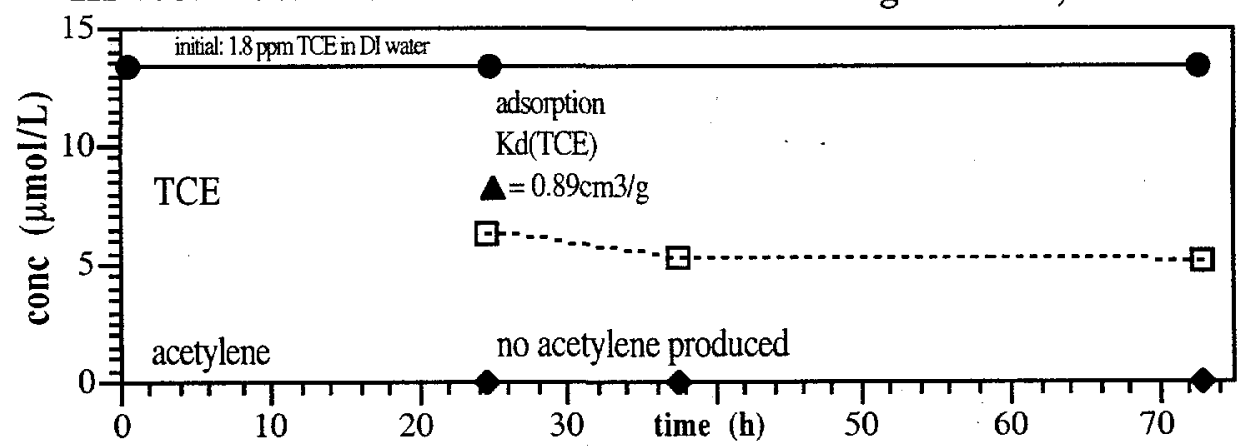

D. 4 
Batch TCE Degradation in Istok Sediment $\left(<4 \mathrm{~mm}, 25^{\circ} \mathrm{C}\right)$ 4.0\% reduced (calculated)

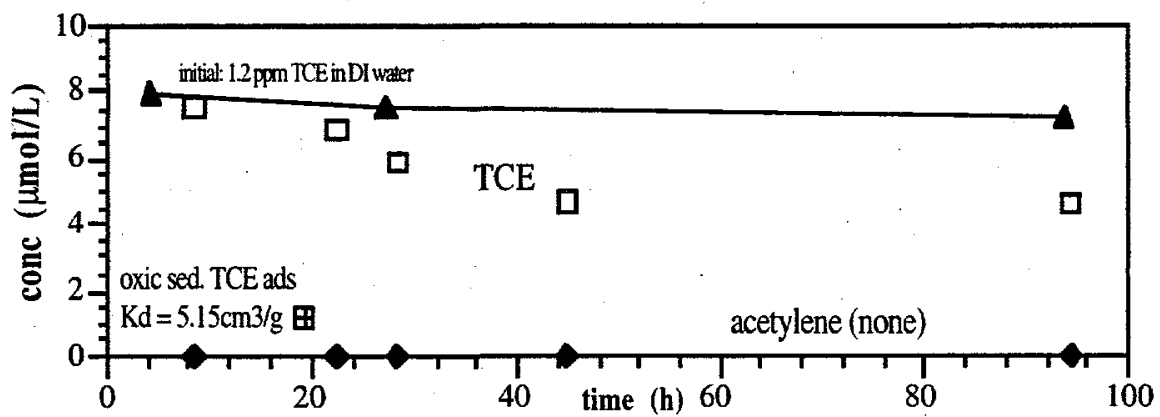

KF42c: Batch TCE Degradation in Istok Sediment $\left(<4 \mathrm{~mm}, 25^{\circ} \mathrm{C}\right)$

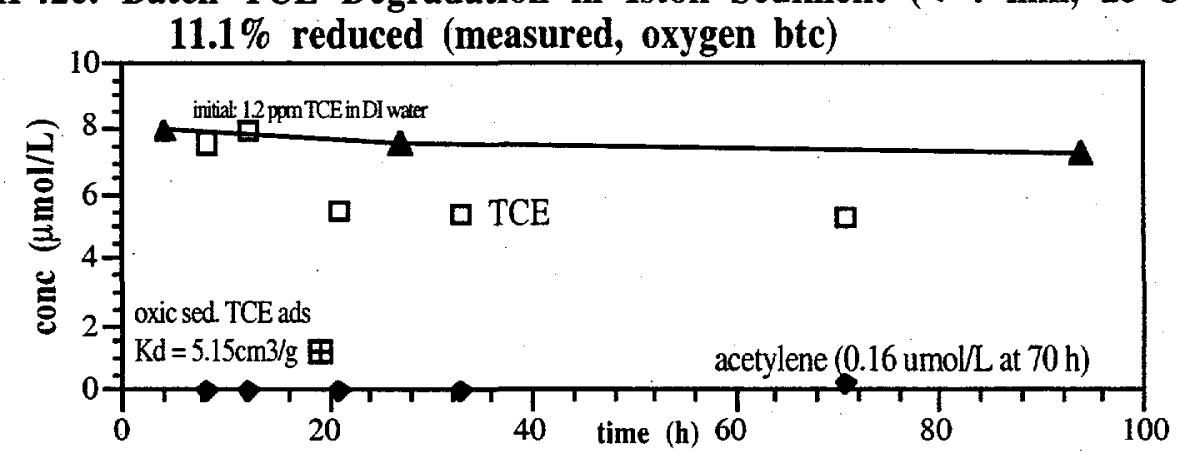

KF42d: Batch TCE Degradation in Istok Sediment $(<4 \mathrm{~mm}$,

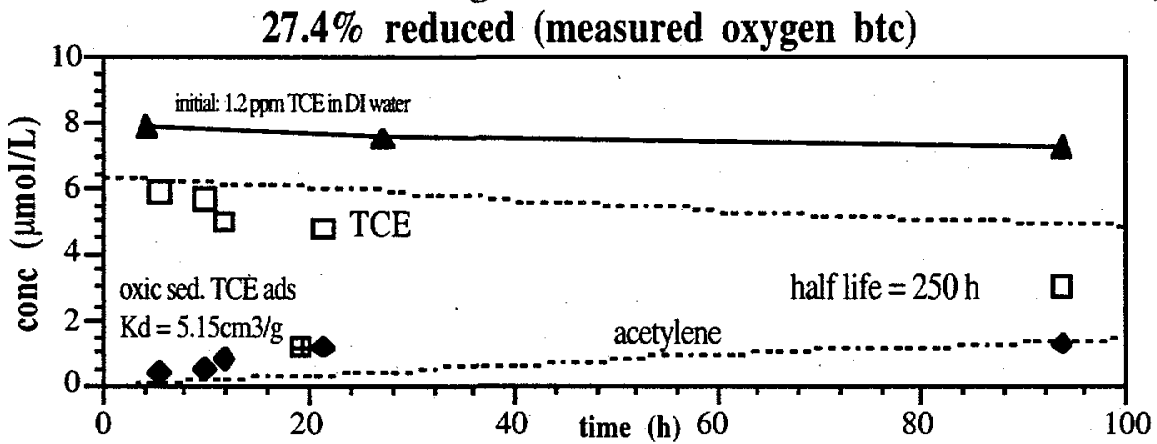

KF42e: Batch TCE Degradation in Istok Sediment $\left(<4 \mathrm{~mm}, \mathbf{2 5}^{\circ}\right.$

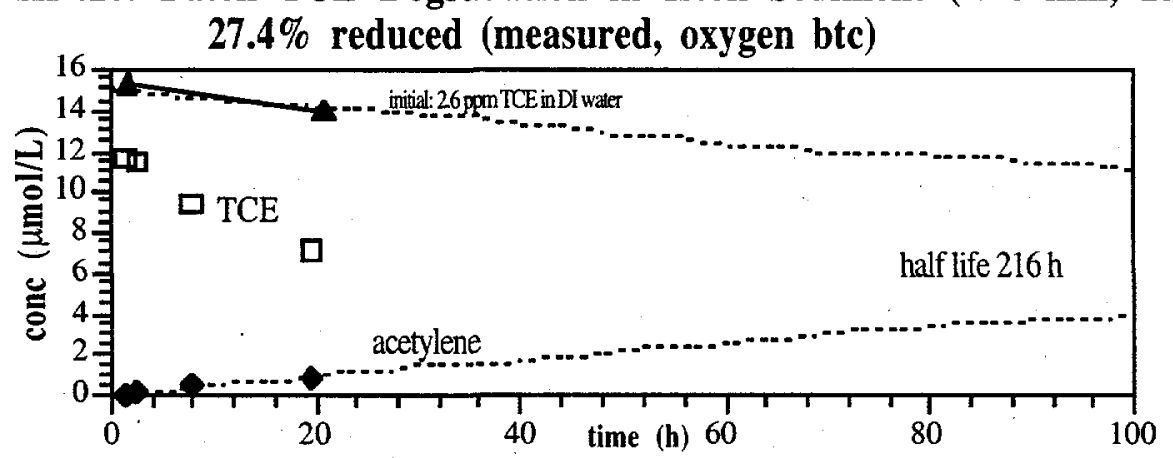

D.5 
KF42f: Batch TCE Degradation in Istok Sediment $\left(<4 \mathrm{~mm}, 25^{\circ} \mathrm{C}\right)$ $33.4 \%$ reduced (calculated)

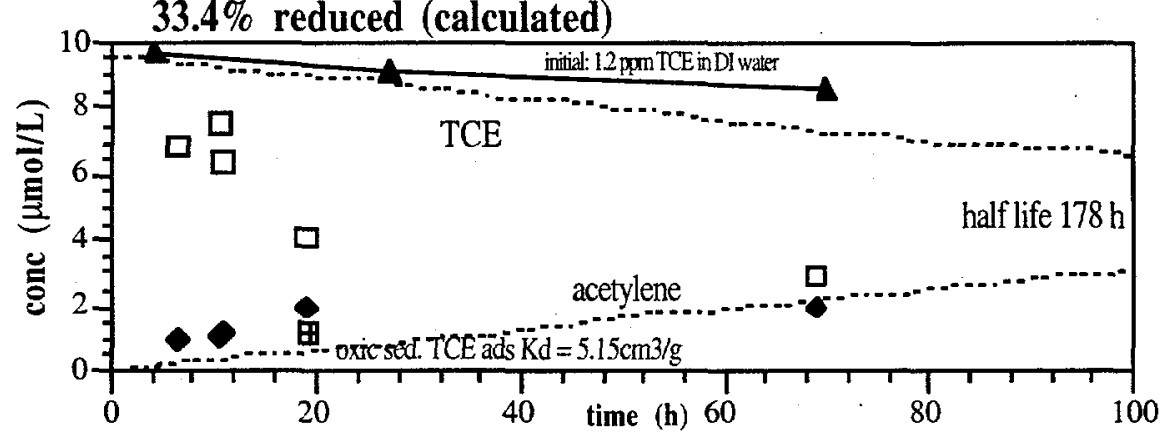

KF42g: Batch TCE Degradation in Istok Sediment $\left(<4 \mathrm{~mm}, 25^{\circ} \mathrm{C}\right)$

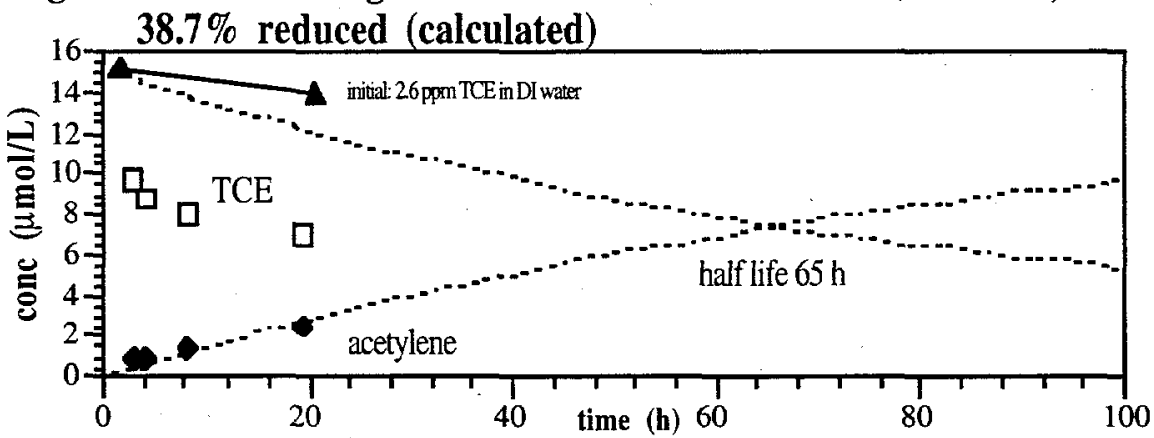

KF42h: Batch TCE Degradation in Istok Sediment $\left(<4 \mathrm{~mm}, 25^{\circ} \mathrm{C}\right)$

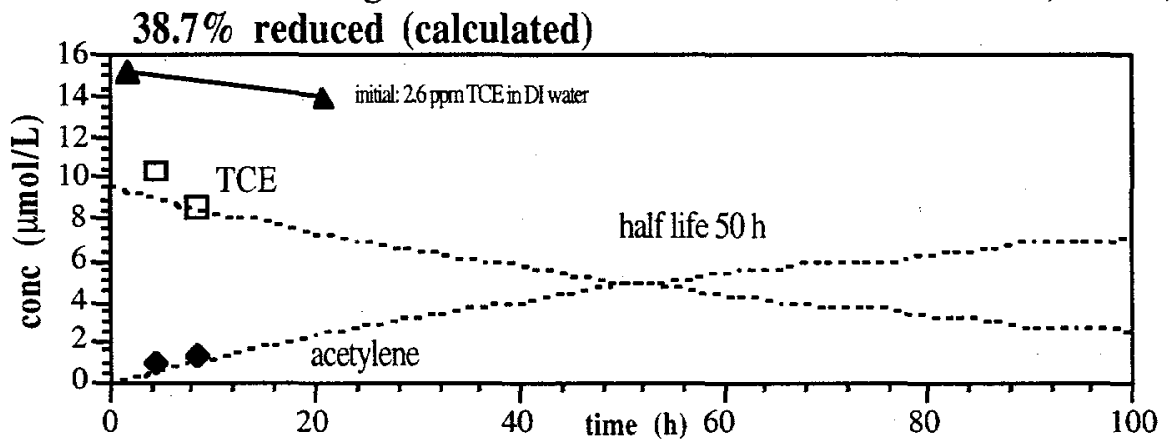

KF42i: Batch TCE Degradation in Istok Sediment $\left(<4 \mathrm{~mm}, 25^{\circ} \mathrm{C}\right)$

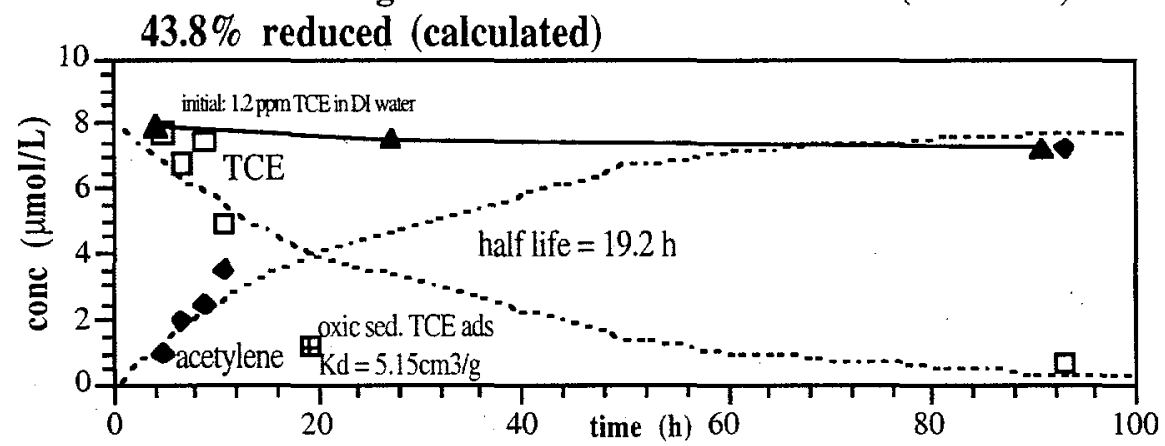


KF42i: Batch TCE Degradation in Istok Sediment $\left(<4 \mathrm{~mm}, 25^{\circ} \mathrm{C}\right)$

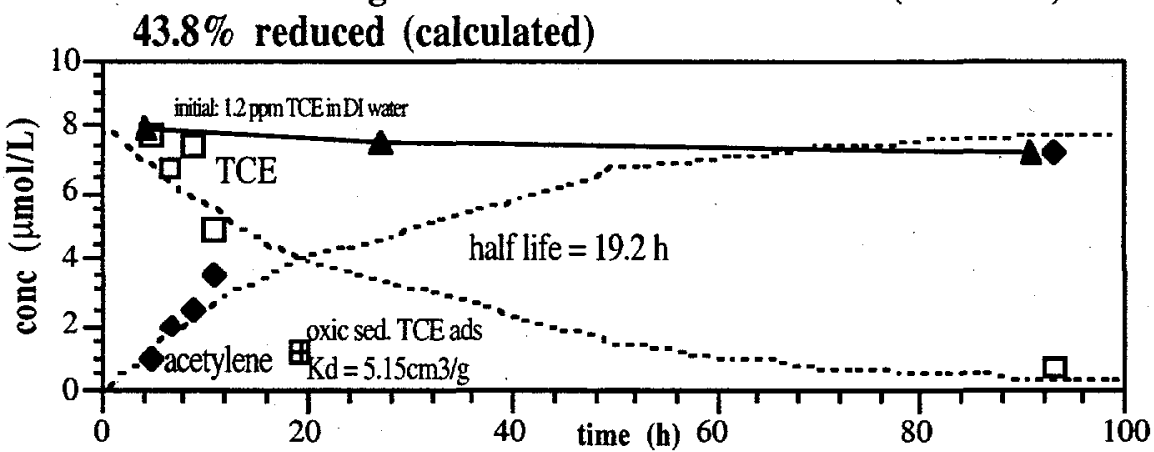

KF42j: Batch TCE Degradation in Istok Sediment $\left(<4 \mathrm{~mm}, 25^{\circ} \mathrm{C}\right)$ $52.6 \%$ reduced (measured oxygen btc)

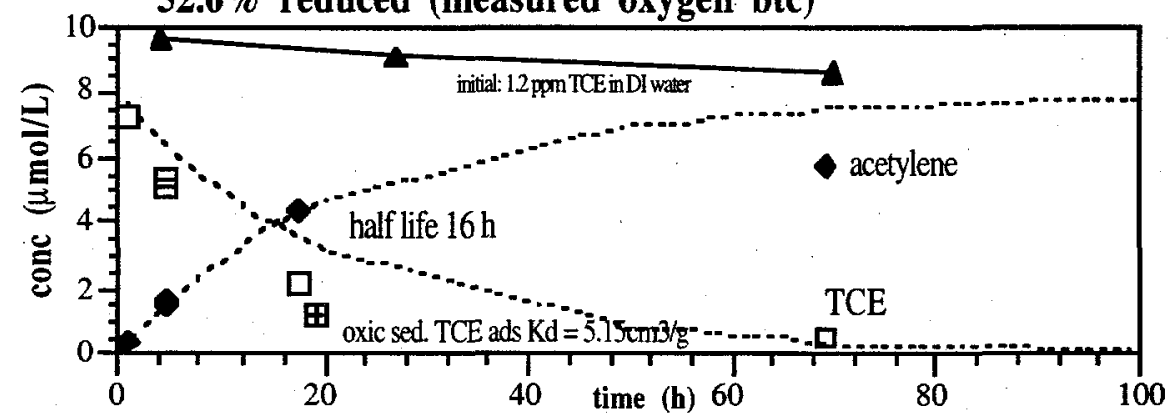

KF42k: Batch TCE Degradation in Istok Sediment $\left(<4 \mathrm{~mm}, 25^{\circ} \mathrm{C}\right)$

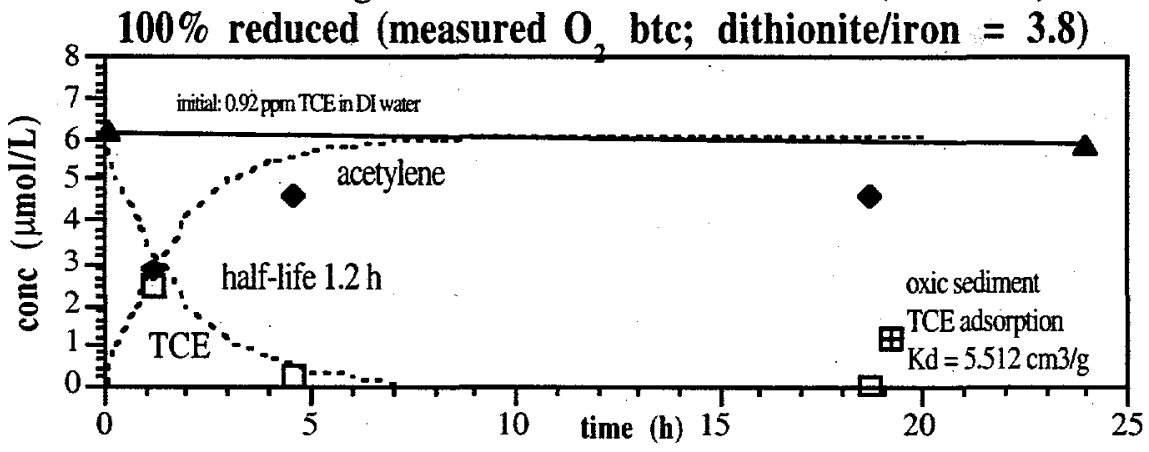

KF42a: Batch TCE degradation at $25^{\circ} \mathrm{C}$, RM1 sediment

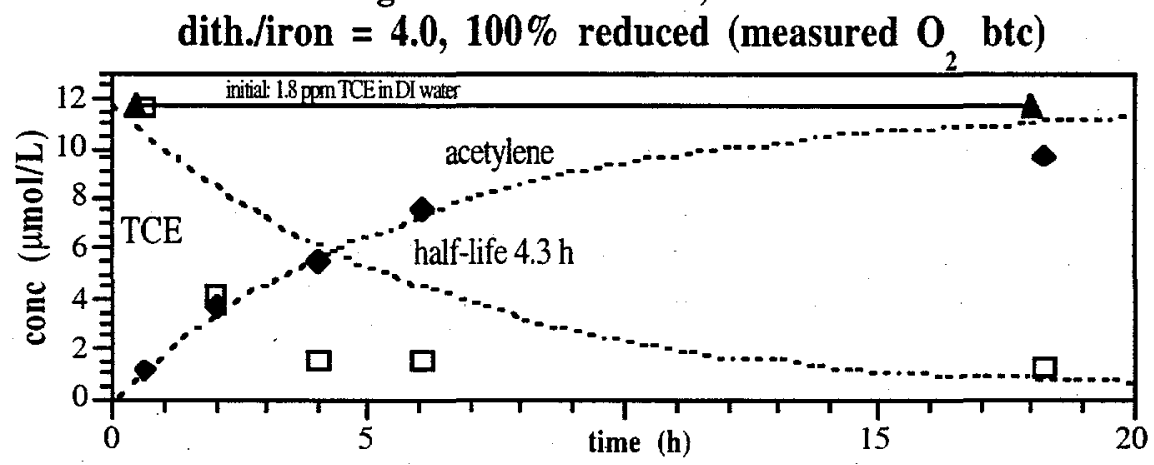


KF62a Batch TCE Degradation:

Reduced by $0.09 \mathrm{M}$ dith $+0.09 \mathrm{M} \mathrm{K}_{2} \mathrm{CO}_{3}$

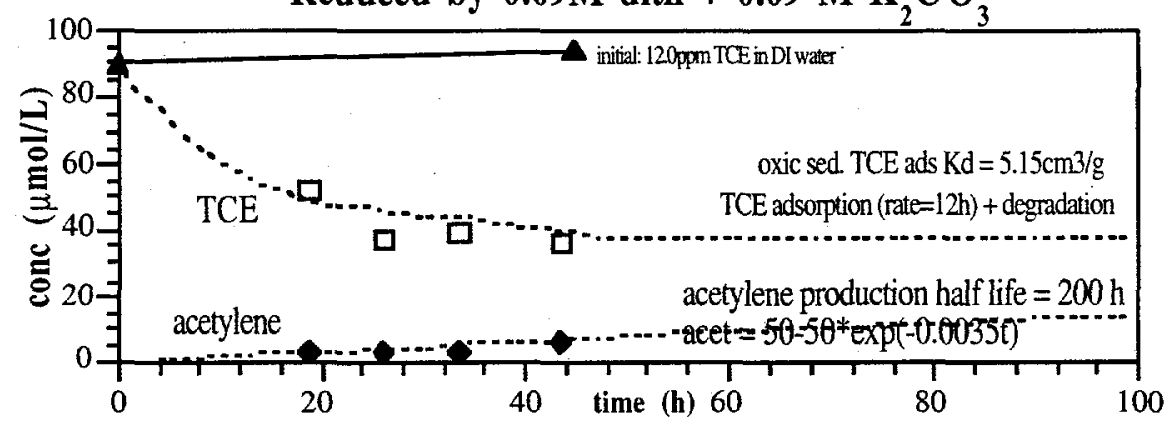

\section{KF62b Batch TCE Degradation:}

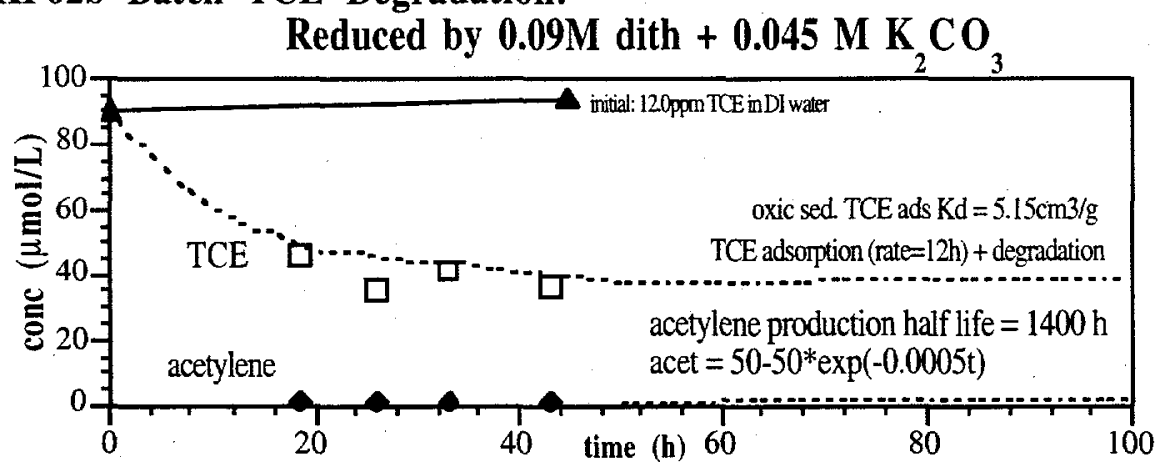

D. 8 


\section{Appendix E}

Column TCE Experiments 
KF17: TCE Degradation in Ft Lewis Sediment

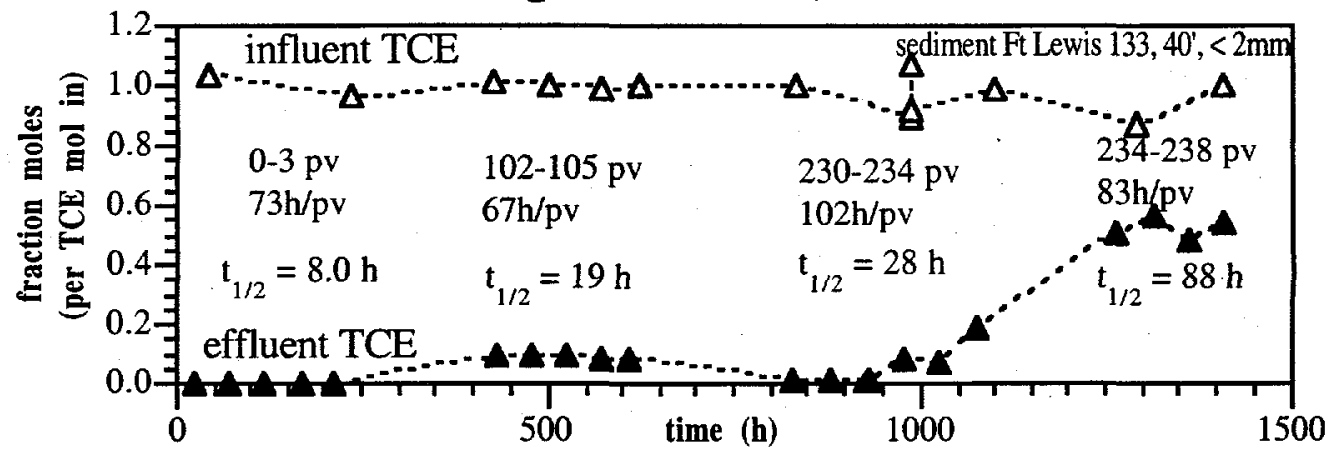

KF17: DCE Reactivity in Ft Lewis Sediment

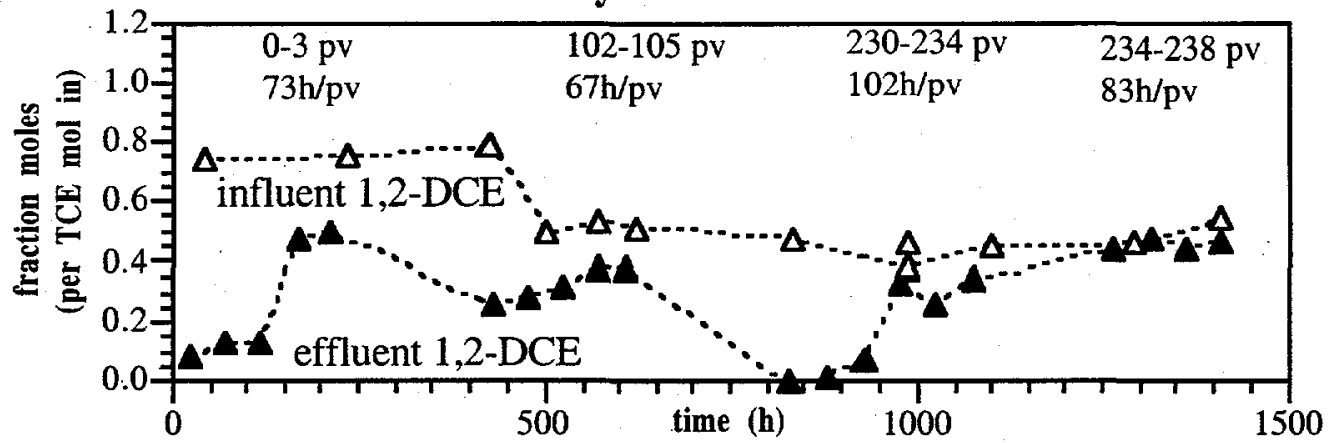

KF17: Acetylene in Reduced Sediment Column

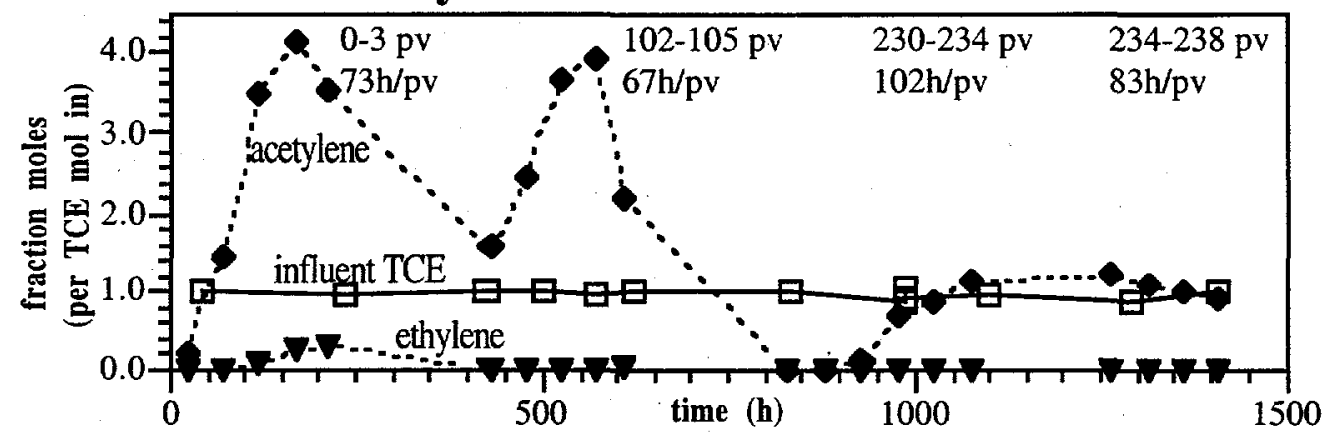

KF17: Chloroacetylene and Vinyl Chloride in Ft Lewis Sediment

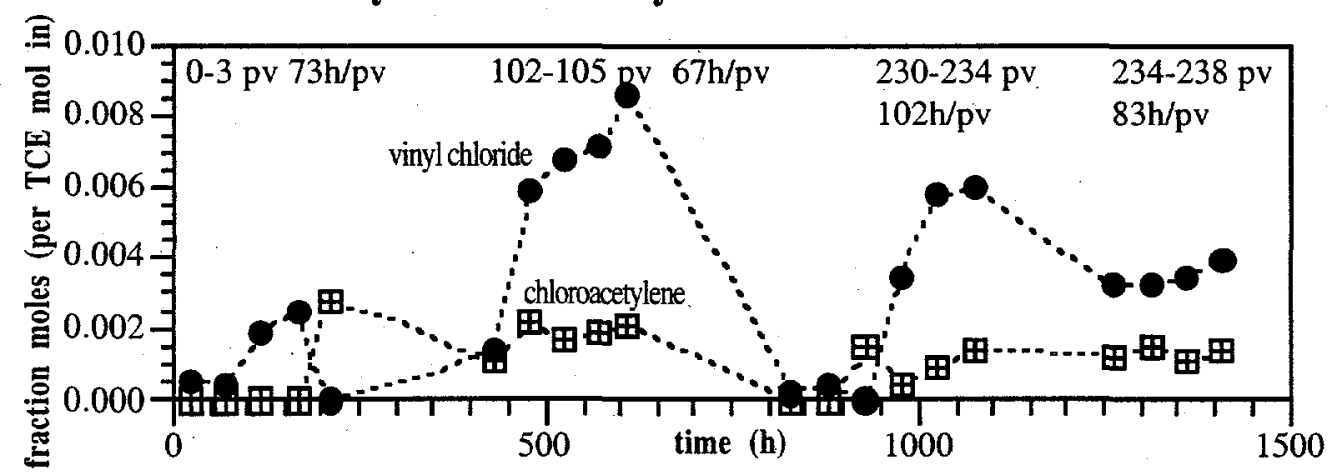

E. 1 
KF23: TCE Degradation in Reduced Sediment Column

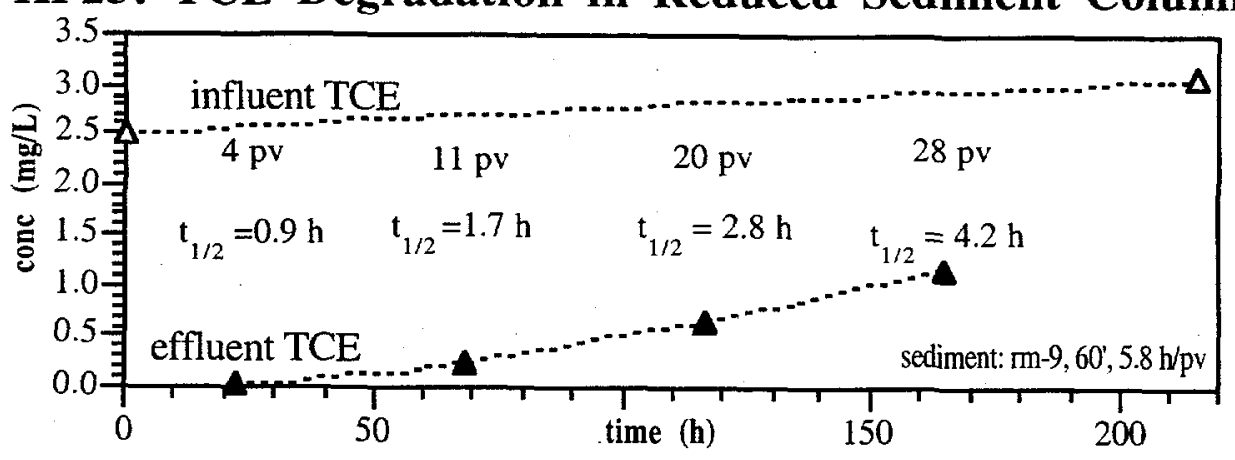

KF23: cis-DCE Mass Loss

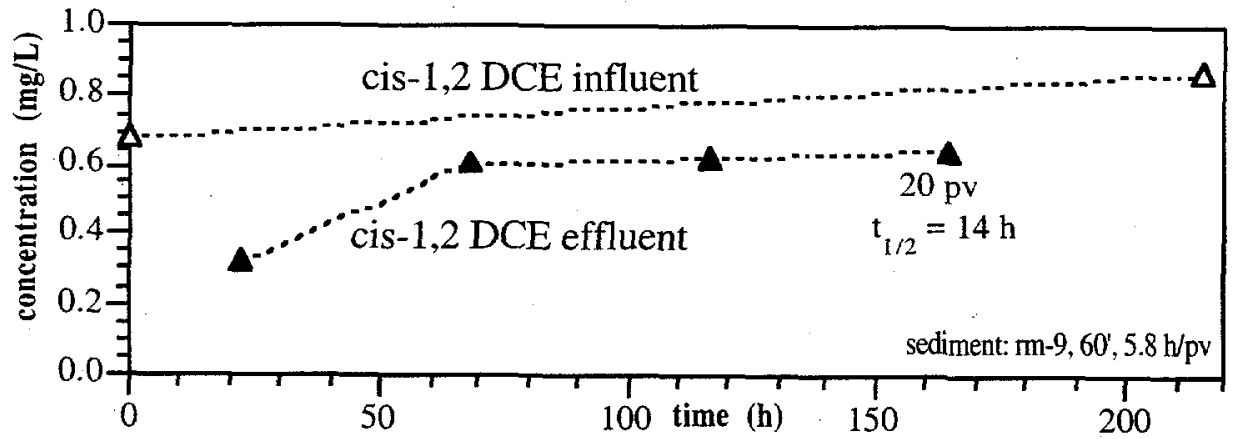

KF23: 1,1-DCE Mass Gain (part of TCE pathway)

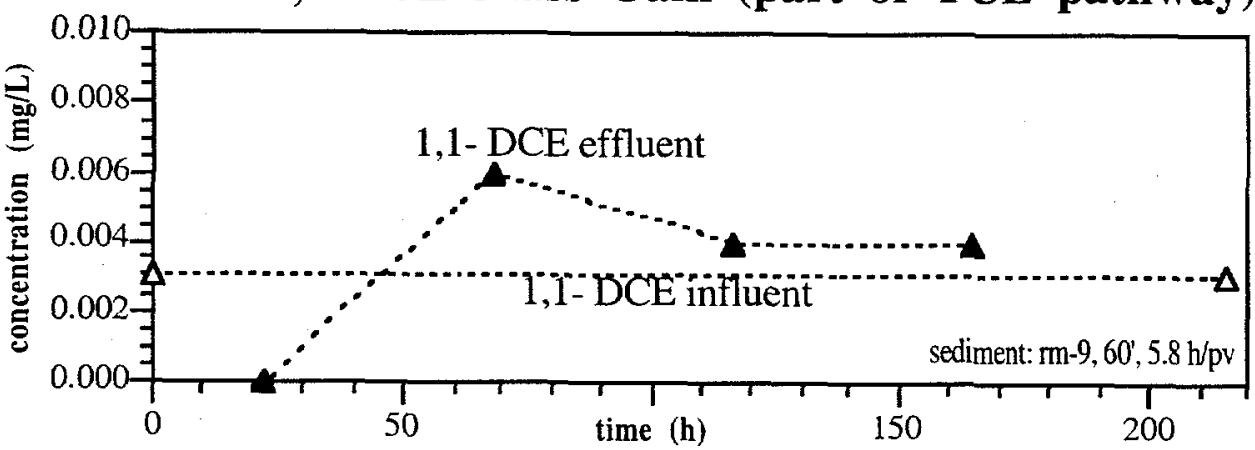

KF23: TCA Degradation by Reduced Sediment Column

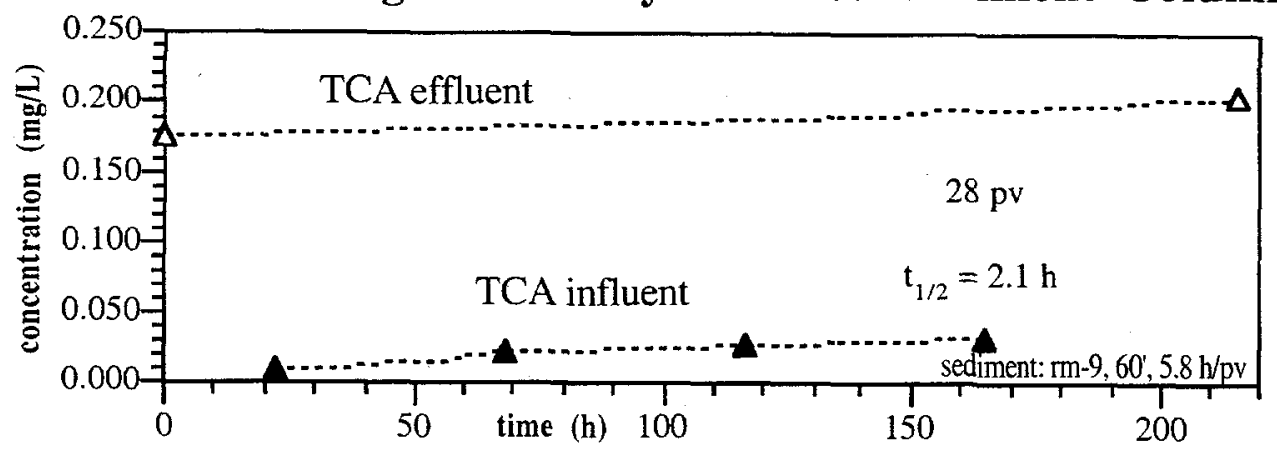

E. 2 
KF38: TCE Degradation with Flow, 10C, 25\% Reduced sedimen

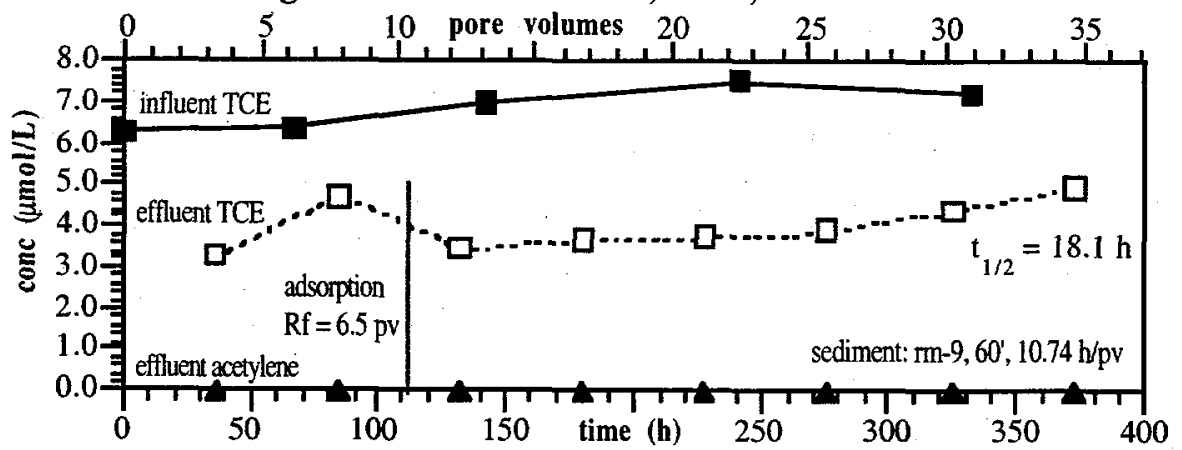

KF39: TCE Degradation with Flow, 10C, $1 / 4100 \%$ reduced sed

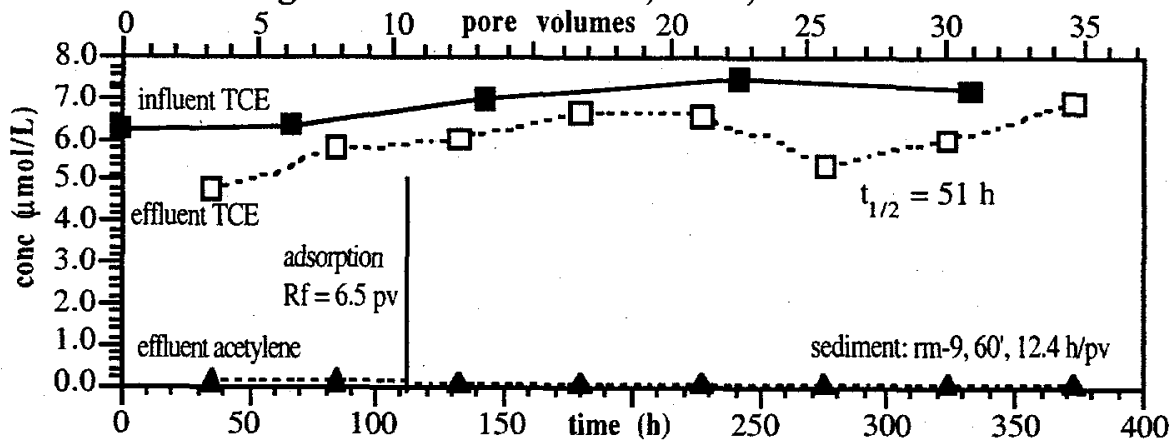

E.3 


\section{Distribution}

No. of

Copies

OFFSITE

Steve Cox

U.S. Geological Survey

1201 Pacific Ave., Suite 600

Tacoma, WA 98402

Phil Crawford

Public Works

ATTN: AFZH-PWE, MS-17

Bldg. 2012, Room 323

Fort Lewis, WA 98433-9500

Rick Dinicola

U.S. Geological Survey

1201 Pacific Ave., Suite 600

Tacoma, WA 98402

Sue Kahle

U.S. Geological Survey

1201 Pacific Ave., Suite 600

Tacoma, WA 98402

Bob Kievit

U.S. Environmental Protection Agency

1200 Sixth Avenue 0EA-095

Seattle, WA 98101

Marcia Knadle

U.S. Environmental Protection Agency

1200 Sixth Avenue 0EA-095

Seattle, WA 98101

5 Dennis Korycinski

Public Works

ATTN: AFZH-PWE, MS-17

Bldg. 2012, Room 323

Fort Lewis, WA 98433-9500
No. of

Copies

Jeff Randall

$\mathrm{CH} 2 \mathrm{M}$ Hill

$777108^{\text {th }}$ Avenue, N.E.

Bellevue, WA 98004-5118

44 Pacific Northwest National Laboratory

C. C. Ainsworth K3-61

J. E. Amonette K8-96

J. G. Bush : K6-96

K. J. Cantrell K6-81

J. L. Devary $\quad$ K6-96

J. C. Evans

K6-96

J. S. Fruchter (10) K6-96

T. L. Liikala (3) K6-96

W. J. Martin K6-81

J. P. McKinley K3-61

K. B. Olsen K6-96

C. T. Resch K3-61

D. S. Sklarew K6-96

J. E. Szecsody (10) K3-61

V. R. Vermeul K6-96

M. D. Williams K6-36

J. M. Zachara K8-96

Information Release (7) K1-06

Distr.1 